Portland State University

PDXScholar

$10-1972$

\title{
Lesson for America? England's development areas
}

Thomas G. Current

Portland State University

Follow this and additional works at: https://pdxscholar.library.pdx.edu/open_access_etds

Part of the American Politics Commons, Comparative Politics Commons, and the Political Theory Commons

Let us know how access to this document benefits you.

\section{Recommended Citation}

Current, Thomas G., "Lesson for America? England's development areas" (1972). Dissertations and Theses. Paper 1567.

https://doi.org/10.15760/etd.1567

This Thesis is brought to you for free and open access. It has been accepted for inclusion in Dissertations and Theses by an authorized administrator of PDXScholar. Please contact us if we can make this document more accessible: pdxscholar@pdx.edu. 
AN ABSTRACT OF THE THESIS OF Thomas G. Current for the Master of Science in Political Science presented October 10, 1972.

Title: Lesson for America? England's Development Areas.

APPROVED BY MEMBERS OF THE THESIS COMMITTEE:

Ronald C. Cease, Chairman

LyndòdR. Musolf

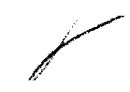

Burton W. Onstine

The work is a descriptive and comparative study of the British program for economically lagging regions of the country. The author's special interest was local participation in the central Government activity. Secondary sources of information on local aspects were in short supply, and the writer relied upon interviews and unpublished documents obtained on a visit to England to supplement published material. His extensive experience in the American development program a1 so was utilized.

The study offers a classification of elements in the programs of the two countries and identifies comparable trends which have carried further in the British experience. The study of these trends can 
therefore be of use in evaluation of the direction and alternatives in the American approach.

Dramatic unemployment in declining basic industries concentrated in Northern England, Scotland, and Wales resulted in pressure on the British Government to create jobs in depressed regions during the 1930's. The author calls this the "Job Development Era." The program feature was the creation of central Government trading estates, or industrial parks. Firms were encouraged to move to suffering regions by the provision of factory sites on advantageous terms, by loans and grants to finance expansion, by loans and grants to local government for needed public improvements, and by retraining programs to prepare indigenous workers to take new employment.

The "Resource Development Era" followed in both countries. In the U. K. it featured the creation of regional development policies, establishment of new towns as favored sites for both industry and workers, resource development grants in the lagging regions, grants to reclaim derelict land, and especially the initiation of a national system of controls on the location of industry and large offices.

The U. S. has not adopted location controls, but in other ways is currently in the "Resource Development Era," in which a depressed region is treated as a whole, rather than concentrating program assistance on particularly severe unemployment pockets.

The chief characteristic of the third and present British stage, the "Balanced Growth Era," is recognition of the need to restructure regional economies in order to enable them to generate their own growth without further special assistance. Britain utilizes regional councils 
and government boards to plan the restructuring process, but only in the 1ate 1960's has major new financing supported implementation. Neither the resources nor the policy commitment has been made in the U. S. to attempt to alter the regional balance of the country. The author made several forecasts from his comparative study, chief among them being (1) that the U. S. will inevitably but reluctantly move into the "Balanced Growth" period in its programing, and (2) that industrial location controls will not be adopted in the same way in the U.S. as in the U. K., but may come as environmental preservation measures.

A key premise at the initiation of the study was that there must be some community and citizen participation in the British program, despite the paucity of printed information on these subjects. After a thorough search of the literature, and interviewing in England, the study did disclose an effective but little known role played by the local authorities. However, the author proved himself wrong in the supposition that the British citizenry and local community organizations have any noticeable impact on the program. In this way it is significantly different than the American experience. 


\section{LESSON FOR AMERICA?}

ENGLAND'S DEVELOPMENT AREAS

by

THOMAS G. CURRENT

A thesis submitted in partial fulfillment of the requirements for the degree of

MASTER OF SCIENCE

in

POLITICAL SCIENCE

Portland State Universicy

1972 
TO THE OFF ICE OF GRADUATE STUDIES AND RESEARCH:

The members of the Committee approve the thesis of

Thomas G. Current presented October 10, 1972 .

Ronald C. Cease, Chairman

Lyndon R.: Musolf

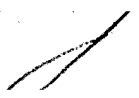

Burton W. Onstine

APP ROVED :

$\overline{\text { Norman N. Greene, Head, Bepartment of Political Science }}$

Dávid T. Clark, Dean of Graduate Studies

December 7, 1972 
ACKNOWLEDGMENTS

I am heavily in debt to Mrs. Mary Burgwin for her volunteer typing, knowledge of proper form (which I sometimes disregard) and academic knowledge in related subject matter, sociology, history, et al (which I do not disregard). I am no more in debt to my wife for her patience than I have always been, but I do acknowledge her ability to render arms length critical judgment which makes me squirm. She seems to enjoy her critical role, in fact.

To our marvelous hosts in Durham City, Dr. and Mrs. Peter Clarke, I am particularly grateful, as I am to other great and hospitable people in the North of England. Peter A. White, author and musician in the city of Darlington, and Richard Adams, staff man with the North East Development Association in Newcastle-upon-Tyne, were particularly helpful.

I also owe a vote of thanks to the Economic Development Administration for permitting me to do my interviewing in England. Lest I cast EDA in doubtful light, I hasten to add that the trip was at my personal expense.

Since the university and public 1ibraries in Portland, Oregon, had very little of use to the purposes of this paper, I came to rely heavily upon Her Majesty's Stationery Office for resource material. I cannot acknowledge a great debt to HMSO, however, since they insisted upon cash. A number of British civil servants rendered invaluable personal aid, however, during my visit to London in 1969. 


\section{PREF ACE}

What has been written about the programs for economically distressed areas in the United States and Great Britain has not been extensive and has suffered from excessive slant toward Washington, D. C. and London. I do not know of any book or substantial article written about the area economic development programs of either nation from the local area view.

My study is an attempt to partly fill that void, despite the absence of demand that it be filled, by describing and analyzing the British program for its Development Areas. My approach, I confess, is prompted by "supply" rather than "demand" factors. My supply of knowledge and experience as a federal official working in the American program is at the "area" level.

The experience which provides the basis for much of my comparative comment, as I describe the program in Britain, dates from August 1, 1961, during the first months of the Area Redevelopment Administration (signed into law on May 1, 1961). I was assigned to the West Coast of the U. S. in this new program and am currently one of the most senior field men in the organization--now called the Economic Development Administration.

An opportunity to visit England and obtain pertinent interviews and background information piqued my interest in the British program. In September and October, 1969, I interviewed a number of national and local figures in England. Before and since, I have searched through 
everything I could find that described or reflected the British program and this paper is the product of such secondary research, larded with the product of my experience, salted with some insight gained in. personal interviews.

Both the wonder and the burden of an interest in economic development is that it leads you seemingly so far afield. Technology, ecology, human behavior, political systems, and nearly every other field of scholarly endeavor crowds economics for a share of attention. A slim volume could be produced which simply describes the British government program, or an even smaller tract could explain the American counterpart. My paper goes beyond such material.

To analyze either or both of the programs, one must include or assume an understanding of the political systems within which the two countries operate their domestic aid. There are differences between the political systems that invalidate a simple comparison of the tools employed to stimulate development in selected areas. Consequently, I have tried to provide some political and social background for examining the British program, while still assuming the reader has some knowledge to start with. A notable handicap is that even the available literature on the inner workings of local government in Britain is scanty; on economic development at the local level it is non-existent. For reasons of space, inclination and credibility, I have avoided international finance, complicated economic and industrial analysis, technology, broad English history, and a number of other subjects which might have a legitimate claim to relevance. What is left to cover is quite enough! 
What do the British do about stimulating or controlling regional or local economic development? With what success do they exercise their techniques and devices for development effort? What is the economic and political situation that affects choice of techniques, and effectiveness? What is the decision-making process which affects location of Industry and employment? How does the British program compare with ours? What might we learn from it?

of deepest interest to me personally is the interaction among the three participants in British regional economic development-central Government, local Government, and the public. The study of economlc development in Great Britain affords opportunities for a very broad range of comment on political questions of local Government structure, community power structure, and citizen participation, which are my chief interests.

In terms of present day research methods, I have been oldfashioned and non-systematic in the sense of computer technique. No computers were used. No general questionnaire was dispatched. The methodology was to read available 1 iterature and government documents, interview and then apply what insight I possess.

There may or may not be direct value in studying British economic development, depending upon what you wish to do with the knowledge. The value is largely indirect. Some trends common to both countries have carried further in Britain. To the American, therefore, it helps to clarify his judgment of program merit and demerit to note what has happened where trends have extended further. This is the purpose of the paper. 


\section{Glossary}

Definition of several key terms used throughout the paper will be helpful.

Industrial Estate or Trading Estate. This concept designates a "planned clustering of industrial enterprises, offering developed sites, pre-built factory accomodation and provision of services and facilities to the occupants."1

Industrial Park. Most commonly in the United States, industrial parks or industrial districts do not include pre-built factory accomodations but often include financial assistance in custom erection of buildings. Otherwise, the American industrial park compares to the English industrial or trading estate.

Industrial Area. As distinct from the above, an industrial area in Europe is an improved site offered as an inducement for the estab1ishment of new enterprises. In the U. S. industrial areas are often referred to as industrial parks, if they are well-planned and prepared for occupancy, but providing pre-built factory space is not common. Industrial Zone. An area restricted to or reserved for industrial use, on which improvements have not been made, is properly called only an industrial zone. Of course, communities and developers often propagandize such areas to the rank of industrial area, district or park.

Economic Development. I have often said, only partly facetiously, that anyone who volunteers to define economic development is inexperienced in dealing with it. James $S$. Duesenberry told the American Economic Association that "economic development seems to be 
one of those peculiar phrases whose meaning everyone knows without the aid of any formal definition. Onward and upward expresses the term's meaning as well as anything else." ${ }^{2}$ Practitioners have to be concerned with more than industrial production. Of interest to the promoter of economic development are not only economic behavior but also political and social behavior, physical planning, opportunities for education and training and for cultural and recreational activity. 3

Thomas G. Current Porti and, Oregon

September 15, 1972 
1 United Nations, Department of Economic and Social Affairs, Industrial Estates: Policies, Plans and Progress (New York: United Nations, 1966), p. 4.

2Val R. Lorwin, "Working-Class Politics and Economic Development in Western Europe," Comparative Political Parties: Selected Readings, Andrew J. Milnor, Editor (New York: Thomas Y. Crowell Co., 1969), p. 112 .

3 Ibid. 
TABLE OF CONTENTS

PAGE

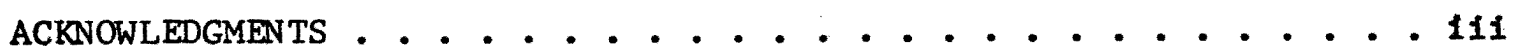
PREFACE .................... IV

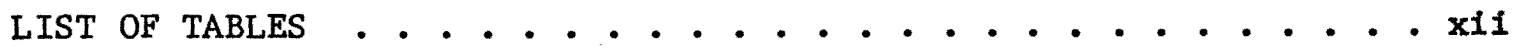

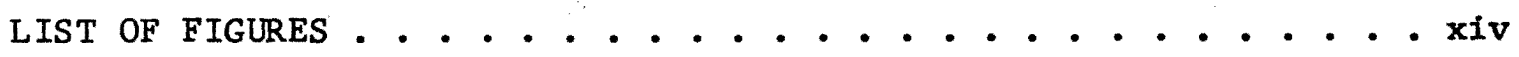

\section{CHAPTER}

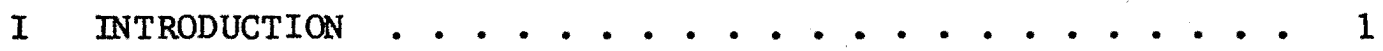

II GREAT BRITAIN, INITIATOR OF AREA DEVELOPMENT .... 10

III REGIONAL DEVELOPMENT POLICY TO $1960 \ldots \ldots$

IV INDUSTRIAL LOCATION INCENTIVES ........ 47

Selection of Areas ........... 47

Government Industrial Estates . . . . . . 58

Control of Industrial Location ......... 62

Grants to Industry ........... . . 68

Loans to Industry . . . . . . . . 70

$\operatorname{Tax}$ Concessions ............. 76

Education and Training ......... 78

A Case of One That "Went Wrong!" . . . . . 82

$\mathrm{V}$ LOCAL GOVERNMENT PARTICIPATION. . . . . . . . 88

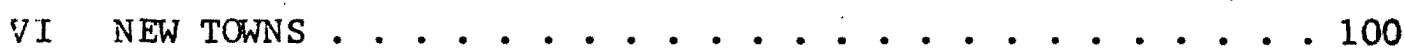

VII BRITISH REGIONAL PLANNING . . . . . . . . . . 111 
CHAPTER $\quad$ PAGE

VII POLITICAL IMPLICATIONS 142

$\begin{array}{ll}\text { IX CITIZEN PARTICIPATION } & 148\end{array}$

$\begin{array}{lll}\mathrm{X} \text { CONCLUSION } & 174\end{array}$

$\begin{array}{ll}\text { BIBLIOGRAPHY } & 195\end{array}$

$\begin{array}{lr}\text { INDEX } & 205\end{array}$ 
I Unemployment by Districts in Selected Years, 1929-1938 . . . . . . . . . . . 39

II Industrial Development in Special Areas,

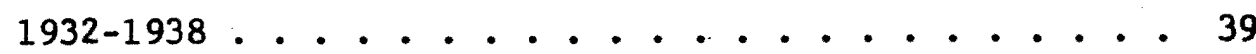

III Post-War Industrial Building in the Development Areas . . . 41

IV Employment in Board of Trade Factories, 1955-1956 ................... 41

V Expenditure on Regional Policy Under the Distribution of Industry Acts . . . . . . . . . . . . 42

VI Estimated Additional Employment From I. D. C. . . . . . 65 VII Original, 1969, and Ultimate Population, British New Towns . . . . . . . . . . 105

VIII Employment in the Seven New Towns, 1951-1969 ...... 108

IX Movement of Manufacturing Industry to Northern

England and to Scotland, 1960-1965 . . . . . . 108

X Job Development Era of Economic Development Programs . • 176

XI Resource Development Era of Economic Development Programs .................. 176

XII Balanced Growth Era of Economic Development Programs . . . . . . . . . . . . . . 179

XIII Economic Development Expenditures--U. S. vs. U. K.

FY 1970 . . . . . . . . . . . . . . . 188 
xili

TABLE

PAGE

XIV Total Assistance (Local Employment Acts 1960-1966) . . . 189

XV Population in Development Areas and Special

Development Areas, 1965 to 1970 ......... 190 


\section{LIST OF FIGURES}

PIGURE

PAGE

1 The Pre-War Special Areas ... . . . . . . . 49

2 The Development Areas, 1945-60 . . . . . . . . 50

3 Development Districts in $1966 \ldots$. . . . . . . . 53

41970 Development Areas and Special Development Areas - 55

5 Special Areas and Industrial Estates, 1939........ 60

6 New Towns of Britain .............. 101

7 Economic Planning Regions ............ 125

8 Comparison of Economic Development Program Systems . . . 151

9 Functional Comparison of Economic Development Programs. - 155 


\section{CHAPTER I}

\section{INTRODUCTION}

The American Economic Development Program

Before turning our attention to the British program, a few paragraphs on the American effort are of interest. The first important legislation in the United States was the Area Redevelopment Act in 1961. The agency offered grants and loans to communities to support their local economic development efforts.

Community "bootstrap" operations of the late 1940's and early $1950^{\prime}$ s, particularly in eastern states, had experienced some success in the development of industrial parks and the attraction of industry. Many of the early industrial parks had been privately financed, but later communities formed local development corporations by selling stock locally. Usually profitmaking in legal terms, they were oriented to community improvement from which the total business community and property owners could profit.

But communities were not always able to pick themselves up by their bootstraps. When Congress became disposed toward helping distressed areas and regions to overcome their economic problems, the techniques utilized were to assist and support the community bootstrap experience. When community efforts floundered for lack of business loan capital to finance new or expanding industry, the Federal program was to make such capital available on favorable terms. Since bank 
investment capital normally had a short repayment period not suitable to high risk investment, the Federal assistance was to be 1ong-term, low-interest loans.

Where industrial prospects were sometimes lost by communities because they were unable to finance or provide the public facilities desired, the Federal program was to supply grants and loans for public facilities which could trigger or facilitate private payroll expansion.

Since many industrial development opportunities were lost for lack of qualified people or funds to do feasibility and other studies, the legislation provided funds to hire the technical assistance necessary to close the knowledge gap in community bootstrap operations.

Finally, the fourth key in the early. legislation was an experimental manpower training program, which has since been expanded into the Manpower Training and Development Act, a major national program not now limited to special areas.

The experience gained in the Area Redevelopment Administration from 1961 to 1965 formed the basis for the Public Works and Economic Development Act of 1965. Late in the history of the Area Redevelopment Administration there was also a move toward a regional program in the Appalachian states. This activity resulted in the creation of an Appalachian Commission by Congress in 1965, composed of the Governors of the affected states and the Federal Government, and enabling legislation was passed as well for other regional commissions. The Appalachian Region, having suffered the greatest unemployment and poverty of any major section of the country, had been the early impetus to the Area Redevelopment Act and became the forerunner of the current 
trend toward regional economic development and planning.'

Currently the Economic Development Administration, an agency of the United States Department of Commerce, has been extended for two years more from July, 1971, and is the primary agency concerned with the area unemployment and underemployment problems of the country. The Small Business Administration al so makes available extra benefits to these areas, and the U. S. Department of Agriculture maintains a continuing effort to coordinate its resources to strengthen the economies of rural areas. Most EDA areas are rural or non-metropolitan areas, in fact. Changes and expansion in the Federal benefits delivery system are probable by mid -1973 .

The EDA program is administered through regional offices which receive, process, and forward project applications to Washington, D. C. for final decision on funding. In each medium-sized state one representative of the agency is permanently stationed for liaison with and assistance to communities and states in utilizing the program. In some larger states, where there are major unemployment problems, two or more such field personnel are assigned, whereas in a few of the smaller states, one field office serves two or more states. The field operation, despite its small size, is notably aggressive in taking its services to the areas and stimulating local leadership to initiate action for economic growth.

The most distinctive characteristic of the program, at least as it is intended to function, is the reliance upon local organization and effort as the keystone of the approach. Areas can qualify on the basis of statistical data denoting high unemployment, low income, or 
persistent economic distress, but to become eligible for funds, local initiative is required. Each qualified labor market area, Indian Reservation or other qualified area must certify to the EDA its desire and intention to participate in the program. The highest level of government, usually the county, speaks for the area. An overall economic development committee is then appointed to represent all of the economic interests, geographic sections, and its minority and disadvantaged groups.

The committee is to be responsible for leading and coordinating the areawide economic development effort. It is normally not charged with physical planning responsibility but cooperates with city and county planning commissions. Local government bodies are represented on the committee but are not necessarily the dominant factor in the program effort.

The idea of the broad-based committee is to involve all elements in the area in the planning process. And, when plans have been shaped and adopted, wide representation is intended to enable the committee to obtain broad support for implementation. Business and industry have not in the past considered other elements in the community as either interested or qualified to work on economic development. Early resistance was evident toward broadening the base in such a community program, but it is generally accepted now that these committees should include organized 1abor, agriculture, education, local government, minority groups, the disadvantaged, and other community forces.

The second major requirement of EDA is that this committee prepare an Overall Economic Development Plan which analyzes in report 
form the economic advantages and disadvantages of the area, and the requirements and opportunities for the creation of additional economic activity and for enhanced liveability. The Plan is the basis for local action and EDA financing of job-creating projects. The latter Includes loans to industry, loans and grants to local government, and technical assistance and planning funds.

A chronic condition of the program, however, is a rather severe limitation on funds and a consequent narrowing definition of project eligibility. The agency recommends that the community do long-range planning, but it is able to finance only individual projects that can readily prove the short-range outcome will be an expanded payroll or a new economic activity.

The agency has long recognized and acknowledged that it does not have the resources to finance the feasible economic development in the very large number of areas for which the program is held responsible. Nearly one-third of the counties of the United States qualify for EDA assistance.' Legislation has authorized one-half billion dollars per year for public facilities, but usually receives no more than 250 million in appropriations from Congress. Other agencies also provide financing in community infrastructure nationally, but the total amount available is a pittance compared to the 25 to 50 billion dollars in pressing needs. Therefore, EDA has taken the position that the greatest benefit from its program will come from the stimulation of organized local effort, from the pyramiding of 1 ocal and state resources topped off with EDA funds, and from improved planning and promotion, rather than from the limited funding of projects which it is able to do. 
EDA direct funding is used as a carrot to attract other effort and financing.

Who Is Involved in Economic Development Programs?

In Great Britain, apart from the investment decisions of private Industry, only government officials are normally involved in location of Industry. The English community is not as much the pluralist organism that the American city usually is. Moreover, local authorities receive all powers from the national legislation and local decisions are made within the detailed framework prescribed by the central Government. It is reasonably clear as to who makes the decisions in Britain and where they are made, whereas both fact and suspicion in the United States frequently point to figures outside the elected and official govermental structure. There is no significant citizen participation in England's local economic development program, a notable contrast to the American approach.

On the other hand, there is much more extensive local government participation than the written materials on the subject imply. Most published work stresses the central Government role. But local planners, for instance, are much involved in economic development decisions and other consequential public decisions. It should be said that English planners are immensely more powerful than ours. What our planners try to do by persuasion, or guile, the English do by routine exercise of law, and they work in an atmosphere in which drastic planning decisions are commonplace.

However, the trend in Britain is toward more citizen checks on planning decisions, while the American trend appears to be toward 
firmer planning support. Furthermore, there is increasing British interest in governmental reform and stronger local and regional government operations. If the direction is not altered, the British economic development program will be more broadly based than it has been.

Other Significant U. S. - U.K. Dissimilarities

The business and professional class in Britain is growing in size and influence, but it has not yet made itself felt in local government to the same extent as in the United States. The existence of a national planning system in Britain permits countless decisions on location of industry, transportation equipment and routes, urban redevelopment and housing to be made in accordance with national policy. The existence of planned industrial areas is of relatively greater importance in Britain, since agricultural or other open 1 and can seldom be changed to industrial at the behest of industry. Much of the suitable open industrial land, furthermore, is owned by government. Finally, the building of any sizeable office or factory building is subject to a permit system. For all of these reasons, there are significant differences between the U. S. and U. K. programs for the attraction of industry to selected areas.

Great Britain in its Town and County Planning Act of 1947 began a total 1and-use planning system which no state in the United States, much less the nation, has approached. Oregon, for instance, now has an official target of 1972 for all its counties to have embarked on border-to-border comprehensive planning and zoning, but completion is unlikely to be on schedule. 
The location of industry in Britain involves processes of planning (site, housing, community infrastructure, training, etc.) which are handled in an orderly manner and are generally accepted by all concerned. Industry, and indeed the population, in Britain is accustomed to direction and control quite beyond the American experience. The density of population is one reason more regulation has been required to make Britain's island home liveable. A further significant factor has been the political development of the country from monarchial origins, and the necessity for centralized control during the survival crises of the two world wars.

Another difference is in knowledge of the benefits of incentive programs. There is generally little knowledge of the American program in industry because the benefits are too limited to receive widespread attention. However, all British manufacturing industry is eligible for some type of government assistance, regardless of location or type of industry. This leads nearly every industrialist to check his eligibility for special benefits, especially those accompanying certain locations. In no case can a significant building or factory be built without government permission, and accordingly with direct exposure to government program information. Consequently, British incentives are more widely known and used than American incentives.

British companies also may be more willing to go through some bureaucratic Hell because the quality and quantity of the government loan and grant inducements are very material, quite substantially more than in the United States. There are great differences in degree and emphasis between the economic development incentives of the two 
countries. There is, of course, really no parallel at all in the United States for the British requirement of a permit to build any significantly sized building and the central control of fiscal and economic planning.

\section{On the Other Hand}

Despite all the dissimilarities the parallel between British and American regional economic development programs is unmistakable, allowing for time $1 \mathrm{ag}$ and political differences. The American program has reflected British experience and copies British techniques. The author foresees adoption of several more British methods in America over the next five years, and we shall surely see increasing interreliance between economic and physical planning, "a lá Britain." 


\section{CHAPTER II}

\section{GREAT BRITAIN, INITIATOR OF AREA DEVELOPMENT}

\section{Team Valley Trading Estates}

If economic developers have a Mecca, it has to be the Team Valley Trading Estates in County Durham, England--the original publicly sponsored industrial park. A large industrial area, much of it reclaimed wasteland, now houses over 100 industries employing thousands of people in a traditionally job-poor area.

A part of the conceptual basis for the Economic Development Administration of the United States Department of Comnerce was the thought of assisting publicly owned industrial parks as a means of attracting new industry. Look at the origins of the publicly deve1oped industrial parks of America and you will find the English trading estate. Search out the first one and you arrive at the gates of Team Valley, born 1936, and still going strong.

The birth of Team Valley was dramatic. The Town of Jarrow made it happen, with a bit of luck and help. So let's start with Jarrow! Jarrow is in British history books as the origin of the famous Hunger March. The unemployed of Jarrow marched nearly the length of England to London to dramatize their privation. $90 \%$ of the working population of the town was unemployed. The Palmer shipyard had closed in 1934 and Jarrow all but died with it. Most of the working population were shipbuilders and no one realized better than they did the risk involved 
when a town depends upon a single industry. The idea of a diversified industrial park, to put lots of little eggs in the basket, found a ready market in such a town. 1

But modern, post-World War II Jarrow is not much concerned about the causes of the Hunger March. The Simonside and Bede Trading Estates, along with the Team Valley Industrial Estates, offer factorles to new industries, so local products now include such things as cigarette filter tips, factory-built houses, and acrylic knitting yarn. "Such then is Jarrow--the place in Durham with certainly the proudest history; probably the greatest suffering; and possibly the most enterprise." 2

It was an October evening in 1969 , before a coal blaze in the open hearth, over pastries and tea; an altogether charming evening. The host was Peter A. White, author, musician, raconteur. The writer was a self-introduced visitor to the area, who had read White's book on County Durham. A wise and gentle man, with great knowledge of local history and understanding of the ways of men, the host was talking about the beginning of government trading estates in his home county. Since the Jarrow experience the idea of government trading estates has carried over the world like bird-shot from a gun, triggered by the Great Depression. That the idea's time had come was heralded by The Times (London), which editorialized on July 29, 1935, under the heading, "The Workless Areas:"

\footnotetext{
"Certainly the time has come," said The Times, "for more action and less enquiry." *** The Times called for the application of fundamental remedies....
} 
"There has indeed been no dearth of great and small proposals, and some that appear quite promising do not require momentous dectsions. Take, for example, the suggestion.....with reference to the establishment of trading estates of the type that have been so successful at Trafford Park, Slough, and Welwyn, to mention some of the best known. There is a quite modern demand for 'ready-made factorles with supplies of gas, water, electrictty, etc., already arranged.' The distressed areas are too poor to supply the demand; they dare not contemplate the orlginal outlay. Such estates are assets, not liabilities. Is it to remain true of the distressed areas that the destruction of the poor is their poverty?"3

Peter White ticked off the twists and turns in the pathway that led to the article in The Times. The nationwide depression had been most terrible in North East England, which had depended upon heavy industry (coal-mining, steel, and shipbuilding); the idea was advanced by a young accountant from Middleton-on-Tees, regarded as quite mad ${ }^{4}$, that the successful private industrial park development at Slough could be used as a model, if government finance were arranged; contacts were made by that accountant, later to become Sir Sadler Forster, A.C.A., Chairman of the English Industrial Estates Corporation, with Sir Horace Wilson, the Chief Industrial Advisor to His Majesty's Government, and with Mr. (later Sir) Malcolm Steward, the first Commissioner for the Special Areas; the famous march on London of unemployed Jarrow workers caused Jarrow to become known as 'the town that was murdered;' and finally a very unsatisfactory debate in 1935 in the House of Commons prompted a letter to the editor from Sir Sadler, thus stirring The Times to protest. 5

The newspaper article turned on a spate of letters to the editor, a public debate, and then, more spurred than convinced, the Government adopted the industrial estates proposal on August 16, 1935, less than a month after the tempest tossed by The Times. 6 
The idea of the trading estates was not in itself new. Trafford Park, Manchester, laid out in 1896 when the ship canal was completed, is the oldest in Britain. The second was at Slough, Buckinghamshire, now the largest privately operated estate in the United Kingdom, begun in 1920, "when industrialists were beginning the colonization of Outer London actively." Slough used a War Department site close to a main railway line and the great West Road, and initially peddled existing buildings until they found the market for them so good that they started building new factory structures. 7

But the idea of putting a trading estate in an unattractive place, away from major markets, as a draw for consumption-type industries, was radical. It was acceptable largely because nothing else seemed to be working. Support of private capital showed no signs of succeeding in the desperate areas. The First Report of the Commissioner for the Special Areas, July 4, 1935, reported that a psychological factor was at work.

The very fact that they are distressed not only reduced their power to attract industries, but to some extent reacts on the inhabitants themselves, who seem to have partially lost confidence in their own districts. This is evidenced by the difficulty in obtaining a moderate amount of finance locally to establish industries. 8

Partly on the advice of Sir Horace Wilson, who believed that the North East Region would be stronger for recognizing that it was an economic unit based on the County Durham coal field, the North East Development Board was formed in 1935 under the Presidency of Lord Ridley. It was "to meet the need for united action and to reduce inter-district competition for new industries. 9

Many areas of the United States have belatedly reached similar 
conclusions ( 35 years later), while many more have not taken even this early step for effective action.

But early results in North East England were not very promising. "Bvery town of any size in the County had notice boards on its outskirts offering 'sites for new works,' though they were not too Interested in the smaller firms that made up most of British industry." As SIr Sadler says, the number of unemployed seemed overwhelming and a six-man payroll (such as later settled in Team Valley) didn't seem worthwhile somehow, though it 1 ater grew to employ two thousand. 10

There was nonetheless national notice of the great new concentration of growth in the London and Midlands (Birmingham) areas even in the Thirties, which were "growing too large and too quickly," while areas dependent on heavy industry were suffering from acute depression. 11

From 1932 to 1935 there was a net increase of 311 factories in Britain, but an increase of 378 in Greater London....there was a net loss of four from the Midlands,... of 99 from the north-west, of 54 from the north-east and of 29 from Scotland. 12

This concern was not new in England. James $I$ is quoted as expressing his alarm over London's growth at the expense of other areas, and Sir Thomas Roe (1641) said, "In my opinion it is no good state of a body to have a fat head and lean members."13

The Dawn of Community Industry Development

From this beginning, with pressure mounting and few alternative ideas at hand, the Minister of Labour was to report to Parliament in March, 1937: 
In order to test more fully the extent to which industries of a lighter type could be attracted to these areas it was decided to make an experiment... . The first of these estates was set up in August, 1936, on a site in the Team Valley near Gateshead. 14

The outcome, in Sir Sadler's words, was:

From henceforth it was to be factory space and hard-working adaptable work people on the spot that would attract industrial undertakings. The idea that the Area had inherent disadvantages began to disappear as soon as the first new factories got under way. In its place came the realisation that in a world of developing road and air transport a modern factory--and particularly one to let built and owned by the State--could be used successfully to influence the location of certain types of industry. This was the most important lesson on location of industry which emerged in the inter-war period. World War II developed it as 'dispersal of industries'; even building factory space ahead of demand. Post-War Britain used it as the basis of a distribution of industry policy.... The modern factory-to-let had come to stay. It enabled a manufacturer to devote his capital to plant, stock, work-inprogress, etc., instead of locking up some of it in bricks and mortar. 15 .

At Team Valley a bad site was chosen requiring much work to drain,

fill, and counter subsidence from coal mining below, but in August, 1937, the first factory was completed and they began to attract industries from the rest of Britain and the world. Incidentally, but not unimportantly, the Government could direct an alien to where he must start his business, if he wanted to start one. Many Jewish refugees commenced small industries in nursery factories established at Team Valley. A nursery factory is a small building in which a starter industry can then be moved to larger quarters. The refugees from Germany, often on a shoestring because they could not get money out of their homeland, were the real pioneers of the industrial estates. Today a handsome surplus is being returned to the Government from their operation. 
By the outbreak of World War II, the Government had advanced $1,825,000$ pounds for the development of the Team Valley Estates and nine factories el sewhere in the region. About 5,000 people already were employed, many in factories which had not reached their full production. By 1957-58, Team Valley had some 12,000 of the 44,000 workers in new factories in the North East." "The figure is impressive, for it is almost equal to the number employed in shipbuilding and repairing, and is equivalent also to some two-fifths of the labor force in the Durham Division of the National Coal Board...."16 ** The operating organization was originally a company limited by guarantee (1imited liability)--a public corporation with funding from the Govermment. In 1959 the North East Industrial Estates Corporation, and other regional development corporations, were consolidated into one corporation each for England, Scotland and Wales. The Industrial Estates Management Corporation for England now has estates all over England, but the first of its kind at Team Valley still attracts representatives of some 40 to 50 countries each year to see where it started and how it was done. On all English industrial estates there are 119,736 workers, of which 91,888 are located in North East England and 17,492 in North West (1969)..$^{17}$ people.

*In October, 1969, there were 104 tenants employing 18,500

${ }^{* *}$ Coal mining and shipbuilding were and still are the basic industries, although today the coal industry has been nationalized and is operating under the National Coal Board. 
White Paper on Employment Policy, 1944

World War II affected both the employment problems of the country and the use of industrial estates. The industrial estates were used for war industry and there was little regional unemployment in England. Mindful that the condition was temporary, toward the end of the war an Inter-departmental Committee was created to write the Govermment White Paper on Employment Policy (issued in May, 1944) which proposed Special Areas legislation for post-war Great Britain, and this legislation has been the pattern ever since. The White Paper (Command 6527) had this to say:

The Special Areas are not at present depressed, and experience during the War has shown that production there can be as efficient as in other parts of the country. Much social capital is already invested there in the form of houses, shops, public services, etc. Neither this social capital nor the corporate life of these communities can be sacrificed. There may be some small and isolated villages, especially in mining areas, which, owing to permanent changes in industrial conditions, offer no hope of sound economic revival.

But where a large industrial population is involved, the government are not prepared either to compel its transfer to another area or to leave it to prolonged unemployment and demoralization. 18

\section{County Durham}

The author used County Durham as something of a case study, and came to have a feeling of real affection for the area and its people. Visiting the area, meeting its people, and looking at one of the earliest of England's Development Area programs, provided essential insight and rewarding personal experience.

County Durham has been described as" "... one big lump of coal with one and a half million people on top. ${ }^{19}$ It certainly does have 
the visual blight which is associated with coal mining the world over,

but it also has Durham Cathedral, the third oldest university in

England, a number of modern cities, and several New Toms.

01d King Coal, for so long the tyrannical monarch of County Durham, was never a merry old soul. After centuries as the Demon King, he is now a rather sickly old soul, and some think his long reign at an end.

Two thousand years ago Roman soldiers from Spain and Gaul burnt Durham coal, wise men, to keep out the chill north-east winds. Latin monks of Durham Cathedral mined in the Lumley area,....

Cardinal Woolsey, when Lord Bishop of Durham, sold mining rights, like his Bishop predecessors, very much to his own advantage.

From the pitmen's point of view, however, coal is the dirtiest four-letter word in the language. Coal has exploited him, sweated him, underpaid him, swindled him, ruined his health, and maimed him. In many cases it has even buried him. Its centuries old story in Durham has been a tale of the pitman's running battle for social justice. 20

According to the English in other parts of the country, the Durham people are a race, a time, and a language apart. On the contrary, the author found them to be mostly understandable and modern. Mistaken attitudes toward the North are part of the problem of attracting industry. The following excerpts from White's Portrait of County

Durham help us to understand the people and their problems:

Maybe he works down the pit, but not like his forefathers, with a pick in his hand. He is more likely to be an electrician, an explosives agent or a maintenance fitter.

More than likely, the Durham man will enjoy drinking beer, provided it is brewed in the north-east, and as likely as not, he will be a member of a workingmen's club and institute. After the parish church, if not before, the club is the best built place in a mining village.

If he is a Christian in anything more than name, he will probably be a Methodist, simply because the Church of England was so blind to the plight of his ancestors, that 
Wesley was riding about converting them whilst the Bishops of Durham were arguing about their coal royalties, or imprisoning strikers at Auckland Castle.

He will, of course, be an ardent trade unionist, paying his subscription every week, staying away from branch meetings and coming out on strike whenever the shop steward tells him to.

Needless to say, he probably votes Labour. The county was the first to be represented entirely by Labour M. P.'s and though Darlington and Sunderland occasionally fall from grace, or see the light, according to your point of view, the Labour Party usually counts on such massive majorities that only prospective Cabinet ministers are shortlisted as candidates.

In local government elections there is a similar trend, Durham County electing Britain's first Labour council and installing Peter Lee as its first chairman. Unfortunately the result is that sometimes the Conservative opposition is ineffectual and too easily stifled.

If all the villages in England were arranged in order of beauty, most of Durham's industrial entries would come at the end.

Substandard houses, stone in the west, cheap red brick in the east, huddle around the pithead as if ashamed of themselves. Usually they are in long terraces, of ten going down a slope, and giving the impression that they would all fall down if you took away the bottom house.

Ten yards away from the depressing terraces, stand the netties (lavatories), two by two, within easy scent of the tiny kitchens.

Behind this architectural squalor lies the excuse that the mining community is only a temporary one, since a pit starts to die the moment its first coal is drawn.

True enough the mine closes eventually, and the miners move on, leaving a trail of dereliction in their wake. In the past century the pitmen have moved from the hill drifts and shallow shafts of the west to the nine gigantic deep coastal pits drawing coal from under the sea. As a result, the motorist has inherited a network of roads connecting decaying colliery villages. 21

There certainly are sordid scenes dotting the 1 and scape of Durham County, but for all that, it is a beautiful area. As in this 
writer's own Western Oregon, the landscape is intensely green in the summer. The moisture and moderate climate (though goodly snowfall in winter) see to that.

The population of County Durham is scattered in a handful of towns and in the large collection of mining villages. However, the political situation in the county reflects this multiplicity of isolated communities and "every town and village is a law unto itself. - On the central issue of getting new employment each comnunity sees the rest as rivals." 22 But the villages are too unattractive to appeal to new industry. The few growth points are nearly a11 in the larger towns. There are a number of growth areas in the county that are quite modern. In each of nine communities, employment for men has increased by more than 1,000 jobs over the 15 -year period 1951 to 1966 . In these nine areas the number of jobs for men has increased by 25,000 in total, while in the rest of the county the number of jobs for men has fallen by $50,000 .^{23}$

This area, which the author picked for his field work, is historically the most significant distressed area in the world, and to this day one of the active areas in the British economic development effort. British heavy industry has taken its knocks in the world markets and shipbuilding is down, as is steel. Coal is faced with devastating competition from other fuels. Even the nationalized British rail system has gone over to diesel. The Northern Gas Board has abandoned coal gas and is using oil, while the discovery of North Sea natural gas in large quantities in 1966 has led to the development of electric generating stations based on natural gas. As this trend continues, 
Durham's coal fields lose their main customers and mine closures continue. It is envisaged that a gradual decline in British coal output will result in a reduction in manpower of as many as 500 men a week for the next three or four years. Many of Durham's pits are closed and more w111 be. There were only 64 in production in 1966 . It is anticipated that only a handful will continue in the future. ${ }^{24}$

So it is that the economic development effort in County Durham Is still struggling with a deficit of jobs for its population, and it may be another half dozen years before the new employment being created w11l be a solid plus for the area, rather than making up for its annual losses. 


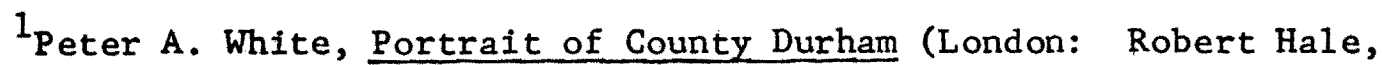
Ltd., 1967), pp. 86-87.

2 Ib1d.

3 North Eastern Trading Estates, First Edition Handbook, Industrial Estates (Newcastle: mimeographed, 1952), pp. 7-8.

${ }^{4}$ Interview, F. G. Donnelly, District Manager, English Industrial Estates Corporation, at Team Valley Trading Estates, Jarrow, England, October, 1969.

${ }^{5}$ Interview, Peter A. White, author of Portrait of County Durham, at Darlington, England, October, 1969.

${ }^{6}$ Interview, F. G. Donnelly.

7T. W. Freeman, Geography and Planning (London: Hutchinson University Library, 1958), pp. 148-49.

${ }^{8}$ North Eastern Trading Estates, p. 3.

9 Ibid., p. 4.

$10_{\text {Ibid. }}$ pp. 5-6.

$11_{\text {Ibid. , p. } 5 .}$

12 T. W. Freeman, p. 117.

${ }^{13}$ North Eastern Trading Estates, p. 5.

${ }^{14}$ Ibid., p. 9.

$15_{\text {Ibid., p. } 10 .}$

16 T. W. Freeman, p. 150.

17 Interview, F. G. Donnelly.

$18_{\text {North }}$ Eastern Trading Estates, pp. 12-13.

${ }^{19}$ Peter A. White, p. 11.

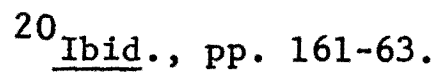

21 Ibid., pp. 173-181.

${ }^{22}$ Ray Thomas, Aycliffe to Cumbernauld: A Study of Seven Towns in Their Regions (London: Political and Economic Planning, 1969), p. 884 . 
${ }^{23}$ Ibid., p. 886.

${ }^{24}$ peter A. White, p. 166. 
CHAPTER III

REGIONAL DEVELOPMENT POLICY TO 1960

\section{Regional Policy in the United States}

Creation of the Tennessee Valley Authority (TVA) as a Federal corporation in 1933 was the first Federal step to directly alter a regional economic imbalance. "Perhaps it was the uniqueness of the TVA program, or the political problems raised by the approach that prevented its replication or use as a model for governmental response to the problems faced by other underdeveloped areas across the country."1

In any case, the history of general regional development policy in the U. S. does not begin in any significant way until 1961. There were several legislative efforts in Congress prior to 1961 , none of which were very successful, and there were several minor administrative steps taken. Sophisticated national economic policy dates back to 1946 at which time the Full Employment Act committed Congress and the Administration to national full employment. Implementation of this policy has been undertaken sporadically through the years, but this was the first major commitment, a condition-precedent to being concerned about employment lags in certain regions.

There was a proposed Economic Expansion Act before Congress in 1949, intended to assist 1abor surplus areas, but it failed. In 1952, Defense Memorandum No. 4 was promulgated by which defense contract 
preference was to be given labor surplus areas. This was the first important administrative step. In 1953, the Office of Defense Mobilization allowed a larger percentage of rapid tax amortization on defense facilities located in labor surplus areas. There was at the time a rapid tax write-off for defense facilities any place in the country, and the 1953 order merely elevated the benefit in certain areas. In March of 1954, the Council of Economic Advisers Task Force reviewed the problem of depressed areas but settled for calling them a local problem and not one that the Eisenhower Administration cared to tackle.

However, in July, 1955, the Congressional Joint Economic Committee proposed national assistance to depressed areas. This became the Douglas Bill, S. 2663. In January, 1956, the Council of Economic Advisers reversed their position and an Administration bill was introduced to assist depressed areas, S. 2892.

The Depressed Areas Bill, S. 964, passed Congress finally in 1958 but was vetoed by President Eisenhower. His Administration had supported a lesser program but balked at the Douglas tack and price-tag. S. 722, another try at a Depressed Areas Bill, was passed again by Congress in 1960; it was again vetoed. In December of that year, President-Elect Kennedy appointed a Task Force on Depressed Areas Aid. The recommendations of this Task Force, partially at least, became law on May 1, 1961, as the Area Redevelopment Act. The effective history of regional development policy in the United States, therefore, runs from 1961 and was discussed briefly in my Introduction to this paper. 
British Regional Policy Needs

British history of regional policy pre-dates the American experience by several decades. These historical factors led to the promulgation of British policy:

(1) Britain was the earliest nation to industrialize and as a consequence found itself spectalizing in industrial exports. The country's prosperity was built on textiles, iron and steel, ships and coal, largely export items. These industries, resource and ocean-access oriented, concentrated in certain parts of Britain. In the 1920's, changes in world markets and technology damaged the prospects of these industries and the national fortunes plummeted. The areas of the country that had developed on the basis of these industries took the full brunt of the decline and the regional problem in Britain was created.

(2) W. W. II temporarily alleviated regional distress, and for several years after the war all industries did well. Eventually the backlog of demand was consumed and shipbuilding, iron and steel began to fade. Competition from the synthetic materials and other fuels tumbled the coal and textile economies, and the regional problem of the thirties was back again in the late $1950^{\prime} \mathrm{s}$. As before, the primary interest was in the distressed industrial areas, although there were other economic problems, particularly in Scotland, which might be called "under" development problems.

(3) As has been noted, there is an additional type of British dilemma, one of congestion in the London and Midlands areas, and one which can be a part of the treatment equation along with the unemployment problem 
of the outlying areas. England and Wales have 837 persons per square mile, a higher population density than any country in Western Europe except the Netherlands. ${ }^{2}$ Over $80 \%$ of the people 1 ive in towns and over one-third live in the seven major metropolitan areas (conurbations). ${ }^{3}$

Nearly all developed nations now have enacted measures which can be described as "regional economic development policies," but when Britain did so in the $1930^{\prime} s$ it was the first acknowledgment in the free world that regional economic forces should be influenced by government policy in a planned way. An authority on regional economic science, Gavin McCrone, sums up:

The problem is...clearly a matter of raising the rates of growth in the less prosperous regions, so that their labour reserves can be more fully utilized, migration reduced, and the income gap between them and other regions closed. In the congested regions, the primary problem is to plan the expansion in such a way as to make the best use of space, minimize the social and economic costs of congestion and preserve the amenity of the environment. This means that some urban concentrations, such as Greater London, for example, must be prevented from further population growth and expansion must be diverted to other centres. 4

\section{Early Legislation}

The history of regional economic development incentives in Britain can be traced to the creation of an Industrial Transference Board in 1928. This first step toward a regional policy in Britain was to retrain 1 abor from the declining industries and provide grants and loans to workers to enable them to move to other areas where expanding industries might provide employment. The policy continued through the $1930^{\prime} \mathrm{s}$, peaking in 1936.5 However, with widespread unemployment, little could be achieved by transferring workers and the intensity of the Great Depression minimized reliance on this policy. 
Regions that were 1 ater to become Special Areas--Scotland, Wales, Northern England, and Northern Ireland--had unemployment rates rising from about $15 \%$ in the $1920^{\prime}$ 's to between 25 and $35 \%$ in 1932 . London and the South East had rates of around 5 or $6 \%$ in the 1920 's, which rose to $15 \%$ in 1932-33. The highest unemployment rates correlated with the location of major heavy industry. 6

In 1934 Parliament passed the Special Areas (Development and Improvement) Act. A Comissioner was appointed for England, another for Wales, "to facilitate the economic development and social improvement of certain areas which had been specially affected by industrial depression...."7 Powers were limited. The Commissioner could not commence projects if government grants were payable, in principle, from other sources. He could not finance profit-making enterprises, either. Major private or public projects were thus handicapped but, by 1938 , some $21,000,000$ pounds had been spent. Action was more in the nature of relief work than economic stimulation. 8

The Special Areas Reconstruction (Agreement) Act of 1936 authorized the Treasury to make an agreement with a corporation, Special Areas Reconstruction Association Limited (SARA), to help finance new business. The Treasury offered a guarantee against 1osses, up to $25 \%$ of total loans made, but the capital of SARA had to be privately subscribed. This approach was limited to small firms and could not therefore have much regional impact. In December (1936) the Nuffield Trust was established on a gift from Lord Nuffield and proved more effective than the SARA program because it could buy stock in industry as well as make loans. 9 
The Special Areas (Amendment) Act in 1937 set up a Treasury fund and the Special Areas Loan and Advisory Commission. Both public faciI1ties and feasible private enterprises were eligible to receive aid. 10 The earlier attempts to pump new economic activity into the distressed areas had met with little important success, and the variety of activities approved under the 1937 legislation reflected both the felt need for innovation and to a degree the feeling of desperation.

Approved projects in the late $1930^{\prime}$ 's included reforestation in the North-East, a national park in Wales, straightening the fens in the River Clyde (shipbuilding areas), draining the mines in Scotland, tunneling under the Tyne River from Jarrow in Wallsend, stimulation of old heavy industries by technical improvements, a clean-up program for some of the Special Areas, and various harbor and dock developments. Other programs under the 1937 legislation included training centers, various health and subsistence programs, and some labor relocation projects. 11

For the long term, however, the greatest employment impact came from the Trading Estates which were established. The location of government factories and government contract operations in the Special Areas also proved to be of value.

\section{The Barlow Report}

Within a year or so, however, it was obvious that unemployment in the distressed areas was continuing and that the problems were still not yielding to the solutions advanced. The government, following up on the report of the Special Areas Commissioner, Sir Malcolm Stewart, appointed a Commission under the chairmanship of Sir Montague Barlow 
to look into the whole matter. The Report of the Royal Commission on the Distribution of the Industrial Population (the Barlow Report) was published in 1940 and was a classic exposition of the theory of regional development policy. It stated a basic policy, which has been accepted by all political parties and the general public in the country, that the trends in the distribution of industry and population were undesirable and that the government should take corrective measures. The Report recommended:

(1) More extensive governmental powers to influence distribution of industry (some seven years later culminating in the industrial location control policy).

(2) Regional economic planning and development (the forerunner of the regional planning organization approach of the $\left.1960^{\prime} \mathrm{s}\right)$.

(3) Attention to linkage between economic and physical planning (again far in advance of substantial acceptance).

(4) A central authority to redevelop congested urban areas as necessary, and to decentralize industry and industrial population from such areas (not enacted in this form).

(5) Consideration of garden cities and satellite towns, industrial trading estates, and expansion of small towns for the purpose of decentralizing industry and industrial population from congested areas (1ater forming the basis for present-day new town and economic development programs). 12

There is very little of importance now being done in British planning and development that was not foreseen or recommended by the Barlow Report, but the war intervened and the Report was adopted 
piecemeal over the next 25 years. McCrone kibitzes:

Since the Barlow Commission were convinced of the economic case for regional development, they emphasized the need for research to promote sound economic development and to identify the problems of regions in advance of a critical situation arising so that appropriate redevelopment could be undertaken. Yet only in recent years has there been any major research activity by Government on the regional problem and much remains to be done.

Likewise, the Report emphasized the role of $\mathrm{planning}$ and the relationship of regional economic planning to new towns and public investment in infrastructure to spearhead regional economic development. The concept of growth areas is alluded to when $i t$ is suggested that some depressed areas may be incapable of development and the resources may have to be regrouped in those locations within the region which offer an environment suitable for development. These ideas were never properly developed in post-war legislation. Regional planning after the physical plans of the 1940 s was abandoned until 1963; new towns were developed more as an instrument of urban and social policy than regional or economic; and, though some references were made to growth areas in post-war legislation, subsequent changes tied regional policy more closely to the criterion or unemployment with little regard for development potential. Yet in the 1960 s these ideas were to reappear and form the basis of many of the changes in regional policy. 13

\section{White Paper on Employment Policy, 1944}

The next critical step was a White Paper on Employment Policy issued by the Coalition Government in 1944. The Coalition Government, succeeded by the Labour Government, did anticipate the renewal of regional problems and openly pledged for the first time to maintain full employment, although not necessarily in all existing communities. Chapter III of the White Paper outlined the measures which would be used to tackle the regional imbalance:

(1) Increasing the efficiency of basic industries to secure overseas markets.

(2) Influencing the location of new industries. 
(3) Resettlement allowances and an adequate housing supply to rent.

(4) Retraining facilities. 14

The new Labour Government in 1945 established, under the Distribution of Industry Act, new Development Districts, somewhat larger than the old Special Areas. Elements of control of industrial location were included. The wartime government had had stringent controls on new building both as to materials allocation and location, and the new program was largely a continuation of wartime controls, but now for the non-defense purpose of influencing industrial location. Various incentives to industry were offered--government acquisition of 1and, government-built factories, loans and grants to industry, loans and grants for basic municipal services, and grants to reclaim derelict 1 and.

The measures to control industrial location were, however, not stringent and it fell to the Town and Country Planning Act of 1947, implemented in this regard in 1948, to introduce the industrial development certificate system. Any entrepreneur proposing to build a factory, a new building, or an expansion, above a certain size, was required to obtain an industrial development certificate (IDC) from the Board of Trade. The BOT would issue the IDC or decline to issue it, and in this decision have an influence upon where the buildings were built. These powers are exercised in this manner by the British government to this day.

The 1950 's

After the Labour Government was defeated, the 1950's saw a decline in the utilization of existing legislation and an hiatus in 
the passage of new legislation to assist the unemployment areas. By 1958, however, the post-war boom was spent and the problems of the Development Districts were so severe as to prompt the previously reluctant Conservative Government to new action. The Distribution of Industry (Industrial Finance) Act of 1958 extended power to make loans and grants in a number of new areas and revived the advance factory program (buildings built in advance of obtaining tenants). No advance factories had been built from 1951 to 1959, although the technique had been a successful part of the earlier industrial development program. One provision of the legislation limited assistance to some of the areas which the Conservative Government believed no longer warranted assistance, while extending help to certain other areas that appeared to be lagging.

In 1960 the Local Employment Act repealed the previous piecemeal legislation and sought to clarify and consolidate. It authorized the Board of Trade to designate and alter area boundaries on the basis of unemployment, either actual or prospective. Earlier the legislation had specifically named the areas to be eligible and the new legislation made this an administrative determination, allowing for flexibility to meet changing needs. New building grants were also offered to industry with which to build their own factories, while the government-built factory program continued and picked up speed.

\section{The Political Process}

Unemployment is a national political problem in all free countries at times and in most free countries all of the time. Unemployed workers, with the right to vote, have both individual and 
collective power; individual in terms of their vote, collective through organizations which represent their interests. Attention to regional economic problems began in response to the political pressures of 1 arge numbers of unemployed workers in particular areas. No free world government can fgnore such problems, although the degree of concern and the means used to solve the problems differ.

There is a powerful emotional appeal which can be invoked on behalf of willing and able workmen who have no work to do, especially in cultures responsive to the "Protestant work ethic." This appeal, of course, evokes a different reaction in different political parties. In the United States, the Democratic Party for many years has had the active support of organized 1abor, and the British Labour Party is even more officially associated with organized 1 abor. In these parties the reaction to regional unemployment was early and vigorous. Both cause and effect were involved, since Labour M. P.'s and Democratic Congressmen enjoyed relatively safe seats where there was a large worker vote. In areas of working-class concentration, uncontrollable industrial change can cause dramatic unemployment, and recognition of this phenomenon produces interest born of fear. Therefore, when Labour or Democratic Party programs are put into effect, many or most of the benefits find their way to the constituencies of their own M. P.'s or Congressmen. This has been known to irritate the Opposition, who have felt that the allocation of resources was being made on a political bias instead of an economic basis.

Robert A. Podesta, head of the American program (EDA) for the Nixon Administration, has told some Republican visitors that EDA 
stands for "Elect Democrats Always!"15 There often is political bias, of course, but generally there is also a natural overlapping of political and economic patterns.

Neither the Democrats nor the Labourites, however, has a totally automatic vote of confidence from the distressed areas. For instance, dissatisfaction was widespread in England's regions, and in the Labour Party, as regional policy was slowed by the deflationary policies pursued by Labour in the mid-60's. Disaffection on this account could have contributed to the Conservative victory in 1970.

\section{Economic Theory}

While there is a general acceptance in Britain of the desirability of regional policy, there is nonetheless a clash of economic positions between the parties. McCrone's summary of the pure free market position describes the basis for the Conservative position, antagonistic to a maximum regional effort:

The free market presupposss that businessmen are the best judges of a location appropriate for carrying out their activities, and that they do a critical evaluation of cost factors which lead them to a clearly defined optimum. It thus assumes that the costs which came into the businessmen's calculation are the only important ones; in other words, that there are no costs either of a social or economic nature that the community is obliged to bear as a result of the decision. It must also be assumed that industrial costs are very sensitive to location, so that if a firm is obliged to go to sites other than the one it first chose its costs will be affected.16

Experienced economic development people, however, have observed that businessmen seldom carry out a fully scientific analysis of all the possible locations. In many cases they simply build their new plant where they are already located, and in other cases make a comparison only between several sites already known personally to 
them. Communities that are competing for new industry know full well that economic factors alone are not always decisive. The quality of the environment, facilities for education and recreation, and other social and psychological factors may heavily influence the decision. The free market view then is an oversimplification of the businessman's calculation of economic consequences. It is equally a mistake to assume that government intervention has no economic costs for a business whose location it does influence.

It is increasingly accepted that in modern society the cost of business decisions cannot be calculated purely within the business, but must take into account the effect on community and national costs. However much merit there may be in government intervention, of course, political parties are naturally at loggerheads over degree and emphasis. The Labour Party has evidenced more willingness to interfere on behalf of the unemployed and ostensibly on behalf of general society than has the Conservative Party. The Conservatives have evidenced more confidence in business judgment than in government, while at the same time recognizing the need for government participation in the location of economic activity.

The British policy under Labour, and which may still prevail, was to build centers well away from the London and South East concentrations, and to select centers for this growth which are currently well below their desirable size and optimum development. Experience seems to have shown that there are a number of industries that can operate in these Development Areas without any considerable disadvantage, or at least with the disadvantages compensated by special government incentives. 
The benefits are better utilization of labor resources in all areas of the country and reduced infrastructure and social program costs.

The policy is not without detractors in both countries. So far, only a theorist here and there has stated the case for deliberate concentration of population in major cities as the most economic means of controlling and conserving the environment.

Even accepting the argument for regional policy, implementation is difficult and chancey. When economic activity declines in an area, whether for reasons of a change in market, technology, or resource base, the situation may become self-perpetuating. Decline is 1iable to breed decline, as growth fosters growth.

A depressed region with stagnant income, unemployment and high rates of net emigration does not provide a buoyant market to encourage new enterprises. It is not, therefore, attractive to capital from other regions and, since there is no barrier to movement of capital, it is likely that capital from this region invested elsewhere will exceed any inflow from other regions. Emigration tends to be heaviest among skilled manpower and those who are potential entrepreneurs.

Moreover, the atmosphere of pessimism which this situation engenders is extremely discouraging to initiative and entrepreneurship within the region. Low incomes mean low tax revenue for local authorities, so that the public investment, which is so essential if the position of the region is to be changed, tends, unless corrective measures are taken by the State, to be on a lesser scale than in other regions. 17

In order to achieve renewed growth in an industrially depressed area, the economy must be reoriented around new key industries, built upon new industrial interrelationships. This is seldom easy because the regional market is deficient, either depressed or underdeveloped. The government incentives have to be very effective, not only to create new jobs but to stimulate a completely new industrial complex capable 
of generating its own growth. The vigor with which the government program proceeds is more important than the techniques used. Programs which distribute token grants and loans, even if some good is done by them, will not be sufficient to help a region restructure its economy.

\section{5-Year Progress Report}

It has to be said that the value of the program in the 1930's was largely research and development. There was little impact on the employment problems of the Special Areas, though some improvement could be shown in unemployment rates due to generally improving economic conditions. It should be realized, however, that the full bag of tricks was not available until the 1937 amendment which came a short two years before the war changed the overall situation. Nonetheless, unemployment still held at about $25 \%$ in the special Areas in 1938. What improvement had been shown, from $35-40 \%$ of the labor force in 1932-4, was largely attributable to improvement in the old basic industries. In 1937, the 23 factories which were opened in the Special Areas, with a population around $10 \%$ of the national total, amounted to only $4 \frac{1}{2} \%$ of the factories opened in Great Britain. In 1938 there was some improvement, with $17 \%$ of the new factories opening in the Special Areas. Greater London on the other hand absorbed $40 \%$ of the new factory development. ${ }^{18}$ (See Table I and TableII). Measurement of effectiveness by comparing factory building data suffers, of course, because so few firms were considering expansion in Depression times.

McCrone concludes that the absence of control on development el sewhere in the country made it difficult for the program to succeed. 19 
TABLE I

UNEMPLOYMENT BY DISTRICTS IN SELECTED YEARS

$$
1929-1938^{20}
$$

as a percentage of insured employees

\begin{tabular}{lrrrrr} 
& $\frac{1929}{5.6}$ & $\frac{1932}{13.5}$ & $\frac{1934}{9.2}$ & $\frac{1936}{7.2}$ & $\frac{1938}{7.8}$ \\
London & 5.6 & 14.3 & 8.7 & 7.3 & 7.7 \\
South-Eastern & 8.1 & 17.1 & 13.1 & 9.4 & 8.1 \\
South-Western & 9.3 & 20.1 & 12.9 & 9.2 & 10.0 \\
Midlands & 13.7 & 28.5 & 22.1 & 16.8 & 12.9 \\
North-Eastern & 13.3 & 25.8 & 20.8 & 13.1 & 17.7 \\
North-Western & 12.1 & 27.7 & 23.1 & 18.7 & 16.8 \\
Scotland & 19.3 & 36.5 & 32.3 & 29.4 & 25.9 \\
Wales & 14.8 & 27.2 & 23.4 & 22.7 & 24.4 \\
Northern Ireland & 14.4 & & & & \\
\cline { 2 - 5 } & & & & & \\
United Kingdom & 10.4 & 22.1 & 16.7 & 13.2 & 12.9
\end{tabular}

TABLE II

INDUSTRIAL DEVELOPMENT IN SPECIAL AREAS

No. of Factories opened:

$$
1932-1938^{21}
$$

Wouth Wales

West Cumberland

North-East

Scotland

$$
\underline{1932} \quad 1933 \quad 1934 \quad 1935 \quad \underline{1936} \quad \underline{1937} \quad \underline{1938}
$$

Total Opened

Total Closed

Extensions

\begin{tabular}{rrrrrrr}
1 & 1 & -- & -- & -- & 5 & 19 \\
-- & 1 & 2 & -- & 1 & -- & 2 \\
7 & 6 & 5 & 2 & 5 & 14 & 26 \\
7 & 3 & 6 & 2 & 6 & 4 & 14 \\
\hline 15 & 11 & 13 & 4 & 12 & 23 & 61 \\
12 & 10 & 22 & 5 & 10 & 6 & 13 \\
6 & 2 & 3 & 8 & 5 & 4 & 6
\end{tabular}

No. of Factories opened in Great Britain

$\begin{array}{rrrrrrr}636 & 463 & 478 & 514 & 942 & 522 & 414 \\ & & & & & & \\ 2.3 & 2.4 & 2.7 & 0.8 & 2.2 & 4.4 & 17.1 \\ 41.0 & 47.1 & 49.2 & 41.8 & 47.3 & 39.1 & 40.6\end{array}$


If his evaluation is correct, it is the major weakness of the current program in the United States where no regional controls on factory location are in operation.

It is notable that evaluation of the British program is statistically possible at all in terms of the building of new factories. In the United States comparable data cannot be assembled in a manner useful to evaluation of the economic development program, because there is not the need to file such information with the government. The fact. of location controls in Britain provides the data to make evaluation of its results possible.

After the war, the Labour Government was in power for one of its infrequent opportunities, úp to that time, to concentrate upon the workers' interests, especially the unemployed workers. It was most anxious to do a job on regional policies.

When the opportunity came, the building control system was strictly enforced, for example, and as a consequence the Development Areas received over $50 \%$ of the nation's new industrial construction in the years 1945 to 1947. The Development Districts at the time had only $20 \%$ of the nation's population. 22 (See Table III).

Neither the Labour Party nor the Conservative Government found unemployment rates of the $1950^{\prime}$ 's to be a great national issue, while inflation and balance of payments difficulties were. Consequently regional development policy faded. There were differences in administration of the industrial development certificate program between Labour and Conservative Governments, but even the Labour Goverment in 1948-51 was not as vigorous as it had been earlier, as Table III shows. 
TABLE III

POST-WAR INDUSTRIAL BUILDING

IN THE DEVELOPMENT AREAS 24

\section{No, of square ft. of Industrial Bullding approved in \\ Development Areas}

Development Areas as \% of all Industrial Bullding in GB

Annual

Average 1945-7 1948-50 1951-3 1954
15.7

7.5

8.1

12.8
51.1

17.2

21.7

18.1
Insured Population of Development Areas as \% of $\mathrm{GB}$

TABLE IV

EMPLOYMENT IN BOARD OF TRADE FACTORIES,

$$
1955-1956^{25}
$$

\begin{tabular}{ll}
$\begin{array}{l}\text { BOT Factory } \\
\text { Space }\end{array}$ & $\begin{array}{l}\text { Numbers } \\
\text { Employed }\end{array}$ \\
$000 \mathrm{sq} . \mathrm{ft}$. & \\
\hline
\end{tabular}

49,000

63,800

62,300

5,500

12,869

14,358

1,413
19.9

18.3

18.2

18.1
South Wales

West Cumberl and

North-West

(inc. Merseyside,

S. Lancs and

$\mathrm{NE}$ Lancs

$$
\frac{1,271}{41,528}
$$
Total Insured Employees May 1954

$000 \mathrm{~s}$

1,020

716

1,194

52
857

3,839 
The amount of new industrial development completed in the Development Districts, in the latter years of the post-war Labour Government (1948-50), was only $17.2 \%$ of the national total, while the population was $18.3 \%$ of the total. 23 The building of advance factories stopped in 1947 not to start again until 1959.

By 1955-56 employment in Board of Trade factory space was 185,900 , about $5 \%$ of the insured population of 3.8 millions in the Development Areas in 1954..$^{26}$ (See TableIV). By 1960, the Board had $45,000,000$ square feet of factory space for 1,095 tenant firms, and the total employment was 201,000 . The increase from 1955 was only 4,000,000 square feet, 10 tenant firms and 15,000 workers. ${ }^{27}$ (See Table V).

\section{TABLE V}

EXPENDITURE ON REGIONAL POLICY UNDER THE DISTRIBUTION OF INDUSTRY ACTS 28

\begin{tabular}{lrcc} 
& \multicolumn{3}{c}{ Millions of Pounds } \\
& Board of Trade & Treasury & Total \\
$1946 / 47$ & 5.7 & 0.2 & 5.9 \\
$1947 / 48$ & 12.5 & 0.3 & 12.8 \\
$1948 / 49$ & 11.0 & 0.5 & 11.5 \\
$1949 / 50$ & 6.5 & 0.6 & 7.1 \\
$1950 / 51$ & 5.0 & 0.8 & 5.8 \\
$1951 / 52$ & 5.0 & 0.8 & 5.8 \\
$1952 / 53$ & 3.7 & 0.3 & 4.0 \\
$1953 / 54$ & 3.1 & 1.1 & 4.2 \\
$1954 / 55$ & 4.5 & 1.7 & 6.2 \\
$1955 / 56$ & 5.9 & 0.4 & 6.3 \\
$1956 / 57$ & 4.9 & 0.3 & 5.2 \\
$1957 / 58$ & 2.7 & 0.1 & 2.8 \\
$1958 / 59$ & 1.5 & 2.1 & 3.6 \\
$1959 / 60$ & 5.6 & 3.0 & 8.6
\end{tabular}

Unemployment problems in the Development Districts were receiving more attention by 1960 , and the political determination 
on the part of both parties was stronger in behalf of regional policy. This was evidenced by the legislation of 1958 and 1960 . It was only with the 1958 legislation that the regional development policy had available to it as much in the way of industrial incentives as had been the case in the 1 ate $1930^{\prime} \mathrm{s}$.

Gavin McCrone concludes that "... if there is a criticism of regional development policy up to this time, it is that the economic aim of stimulating sound economic growth in the regions had not been sufficiently followed up." 29 The Barlow Report was not fully implemented, and the problem regions still were almost entirely dependent upon problem industries for their economic welfare. The growth industries continued to rise in the larger market areas of London and the Midlands. It remained for the $1960^{\prime}$ 's to see a significant attack made on regional economic problems.

In many ways the British regional economic policies of the late $40^{\prime} \mathrm{s}$ and $50^{\prime} \mathrm{s}$ resemble the American economic development program of today. On the books there were a number of tools available, but the commitment in terms of funding and national attention fell far short of sufficient to materially alter the regional imbalance. There was no real recognition that the economies of these areas would have to be substantially restructured in order for them to generate their own future welfare.

Given the determination, the resources, and the opportunity, however, the Labour Government proved it could direct the distribution of industry as a matter of regional policy. Whether the results could be sustained or would be politically palatable over the long run 
were judgments which would have to await further experience. 
${ }^{1}$ Advisory Commission on Intergovernmental Relations, Multistate Regionalism, A Commission Report (Washington, D. C.: U. S. Government Printing Office, April, 1972), p. 16.

2 Britain 1971, An Official Handbook (London: Her Majesty's Stationery Office, 1971), p. 8.

${ }^{3}$ Gavin McCrone, Regional Policy in Britain (London: George Allen and Unwin Ltd., 1969), p. 15.

${ }^{4}$ Ib1d., p. 21 .

$5_{\text {Ibid., p. } 92 .}$

6 Ibid., p. 91

${ }^{7}$ Sumner M. Sharpe, "Depression and Industrial Planning in Great Britain" (unpub1ished thesis, 1958-59), pp. 35-37.

${ }^{8}$ Industrial Estates Corporation of England, "Distribution of Industry Policy" (Newcastle: Board of Trade, mimeographed 1969, p. 1.

${ }^{9}$ Sumner M. Sharpe, pp. 39-41.

10 Ibid., p. 41 .

${ }^{11}$ Ibid., pp. $42-43$.

${ }^{12}$ Gavin McCrone, pp. 101-103.

13 Ibid., pp. 104-105.

${ }^{14} \mathrm{Ibid} ., \mathrm{p} \cdot 107$.

${ }^{15}$ Interview, James R. Faulstich, Assistant to the Governor for Economic Development and Consumer Affairs, State of Oregon, Salem, Oregon, 1971.

${ }^{16}$ Gavin McCrone, p. 31 .

17 Ibid., pp. 80-81

18 Ibid., p. 101 .

${ }^{19}$ Ibid.

${ }^{20}$ Ibid., p. 100.

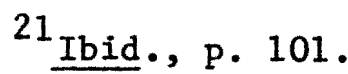

22 Ibid., p. 113. 
${ }^{23}$ Ibid., P. 115.

24 Ibid., P. 112.

25 Ibid., P. 113.

26 Ibid.

27 Ibid., p. 114 .

28 Ibid.

${ }^{29}$ Ibid., P. 119. 
CHAPTER IV

INDUSTRIAL LOCATION INCENTIVES

\section{Selection of Areas}

\section{The Depression}

It was Neville Chamberlain, then Chancellor of the Exchequer, who introduced the bill in Parliament in November, 1934, on behalf of the Conservative Government, known as the Special Areas (Development and Improvement) Act. ${ }^{1}$ The first Special Areas included the central portion of Scotland, particularly Glasgow and Edinburgh. The Welsh area was around Cardiff in the South. The English areas were North East England (County Durham and the Tyneside area) and West Cumberland (in the North West). These were the areas heavily dependent upon textiles, iron and steel, shipbuilding, coal mining, and heavy engineering.: (See Figure 1).

\section{Post-War Development Districts}

One of the pre-war problems with area designations was that the areas had been confined to the small towns and mining villages, while the relatively more prosperous large towns nearby had been excluded. After the war, such towns as Glasgow, Cardiff, Swansea, Darlington, and Newcastle were included with the areas surrounding them. ${ }^{2}$ The new policy recognized that government assistance could only go part way toward making an area attractive for growth, and that assistance would 
be more effective in towns that already had the capacity for growth than in the countryside. Consequently those major towns to which people cculd immigrate or commute from depressed areas, without totally giving up their kinship and friendship relationships, were Included as a part of the post-war Development Districts.

The renamed and redesignated districts were Clydeside (Scotland), West Cumberland, the North East, and South Wales with Monmouthshire, plus in 1946 the Wrexham area and South Lancashire. The Scottish Highlands and Merseyside (LIverpool) were added in 1949 and North East Lancashire in 1953. (See Figure 2).

The United States, which made the same initial error, is following the same pattern of change. The Area Redevelopment Administration designations were based on detailed unemployment criteria. Areas of less unemployment, perhaps economically central to a group of designated areas, were not eligible. After four years of experience, the successor legislation emphasizes the district, or regional, role with a few growth centers in each multi-county area in which investment is most likely to be productive and serve the unemployed of the surrounding territory.

The 1960 's

By 1958 some areas were no longer suffering high unemployment in Britain, while some new ones appeared to be in trouble, especially some small coastal towns. The 1958 legislation provided for Treasury grants and loans to a number of areas called "DATAC Areas" (Development Areas Treasury Advisory Committee areas). Included were some areas in South East and South West England previously having none, and a substantial 
Figure 1. The pre-war Special Areas.

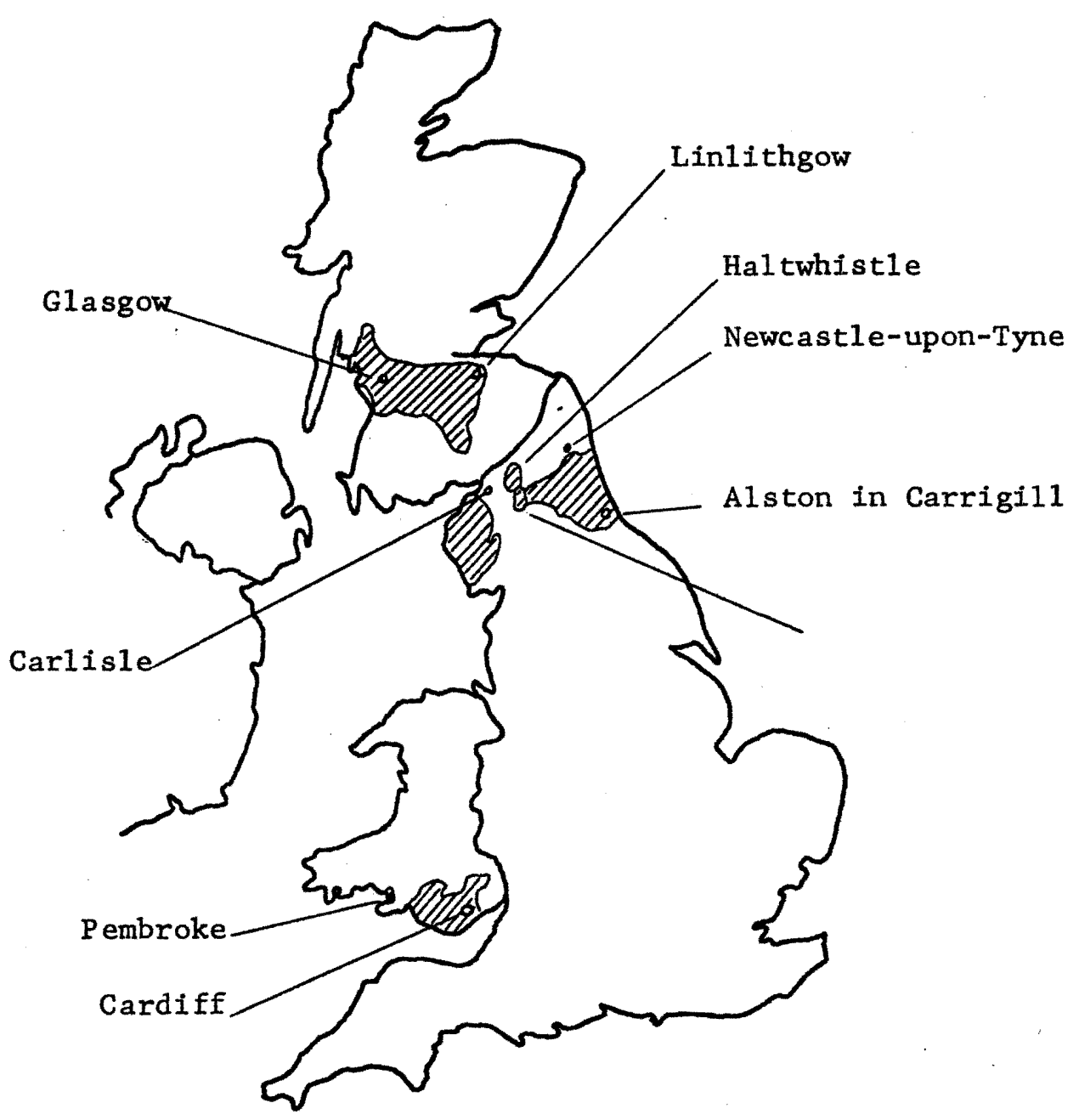

Source: Gavin McCrone, Regional Policy in Britain

(London: George Allen and Unwin, Ltd., 1969), p. 94. 
Figure 2. The Development Areas 1945-1960.

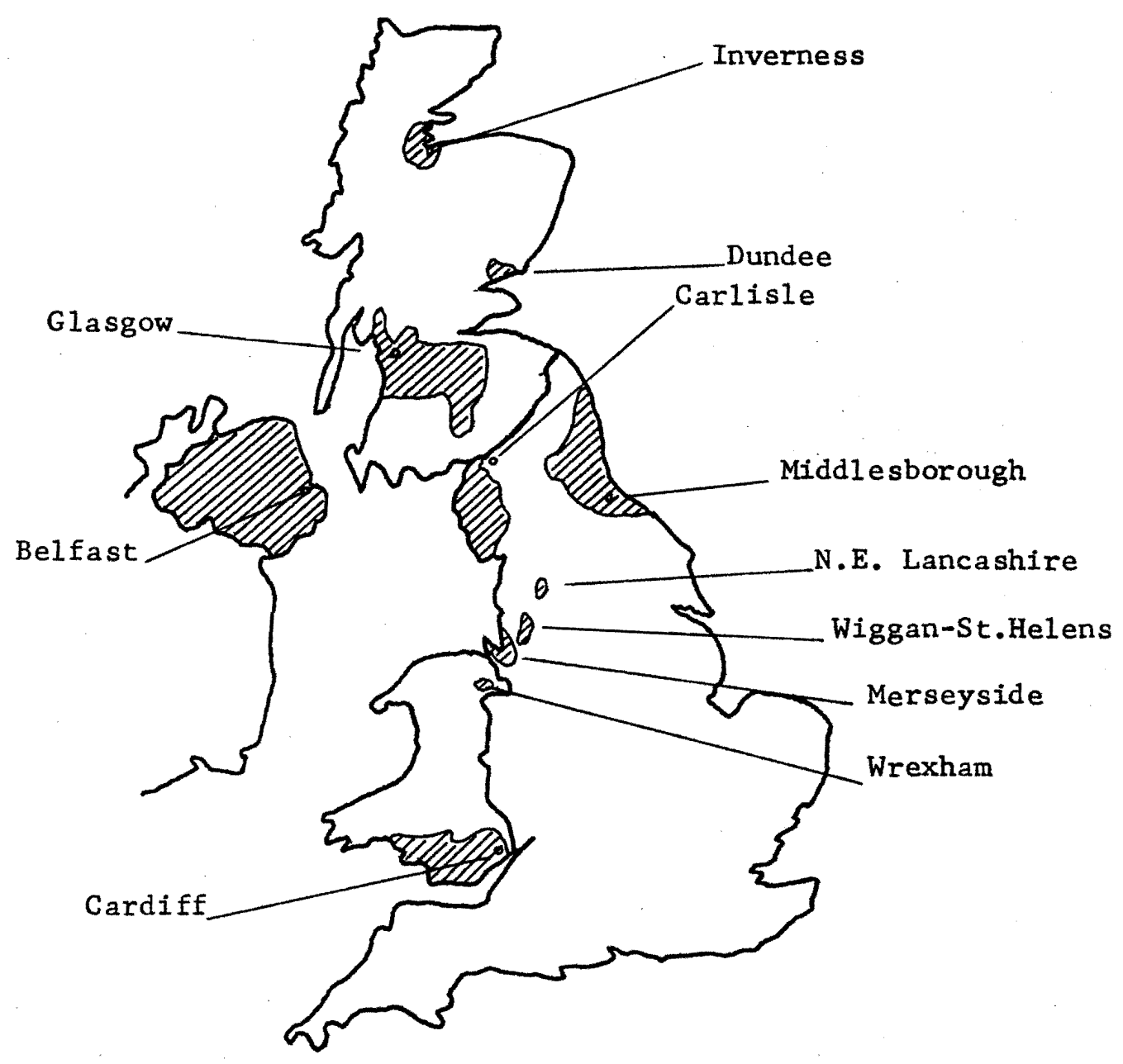

Source: Gavin McCrone, Regional Policy in Britain

(Lond on: George Allen and Unwin, Ltd., 1969), p. 108. 
number of new areas in North West England, plus a scattering of new areas in the regions given previous attention.

An important change was made by the Local Employment Act of 1960 in the manner of designating areas. The Board of Trade was authorized to designate and alter boundaries on the basis of its finding of high unemployment, either existing or projected. From that time until 1966 areas were placed on and taken off the 11st according to unemployment data.

Until August, 1971, this was the system still used in the United States where it has demonstrated the same shortcomings which prompted the English to discard it in 1966. With 1ack of certainty as to duration which areas will be on the 1ist, continuity of planning is difficult, and in some cases the incentive for communities to undertake the always strenuous and uncertain task of bootstrap community economic development is 1 acking, if the area is uncertain of continued government assistance. Businessmen seeking sites hesitate to weigh government aid in their decision unless future eligibility appears firm.

The first published 1ist after the 1960 Act included $12.6 \%$ of the insured workers in Great Britain compared to $18 \%$ in the old Development Districts. However, by 1967 the Development Areas again contained about one-fifth of the employed population of the United Kingdom. ${ }^{3}$ More than economic conditions, the reduction of eligible population in the late $50^{\prime} \mathrm{s}$ and early $60^{\prime} \mathrm{s}$ was a political decision of the Conservatives.

\section{Designation as Economic Units}

In 1963 the National Economic Development Council, a high-level 
advisory body on which Ministers sit together with industry and labor representatives, recommend ed the concept of "optimum use of resources" as the primary justification of special treatment for 1 aggard areas, rather than the social criteria of relieving the suffering of those worst hit by unemployment. By 1966 the result was a shift from the rationale of relieving immediate unemployment in particular localities toward the broader concept of promoting economic development in regions as a whole, taking into account other economic factors besides immediate new jobs for the out-of-work. The United States is belatedly beginning to follow suit.

After 1966 the British Development Districts were superceded by even wider, continuous Development Areas designated on the basis of not only employment and unemployment but population changes, migration, and the objectives of regional policies. (See Figure 3). The creation of regional planning bodies accompanied the broadening of the eligible areas. Five broad areas were designated covering most of Scotland and Wales, the Northern Region, Merseyside, and most of Cornwall and North Devon in South West England. The regionalization of the Development Areas in Great Britain had significance far beyond the matter of areas designation, and will be treated more thoroughly in Chapter VII on British regional planning. For the moment, it is appropriate only to indicate that logical economic units can be treated, in planning and in the use of incentives and building controls, without respect to the immediate unemployment rate in all parts of the area. In the long term the objective is to make the economies of Scotland and Northern England, et al, more self-sufficient so that they have the ability to 
Figure 3. The Development Districts in 1966.

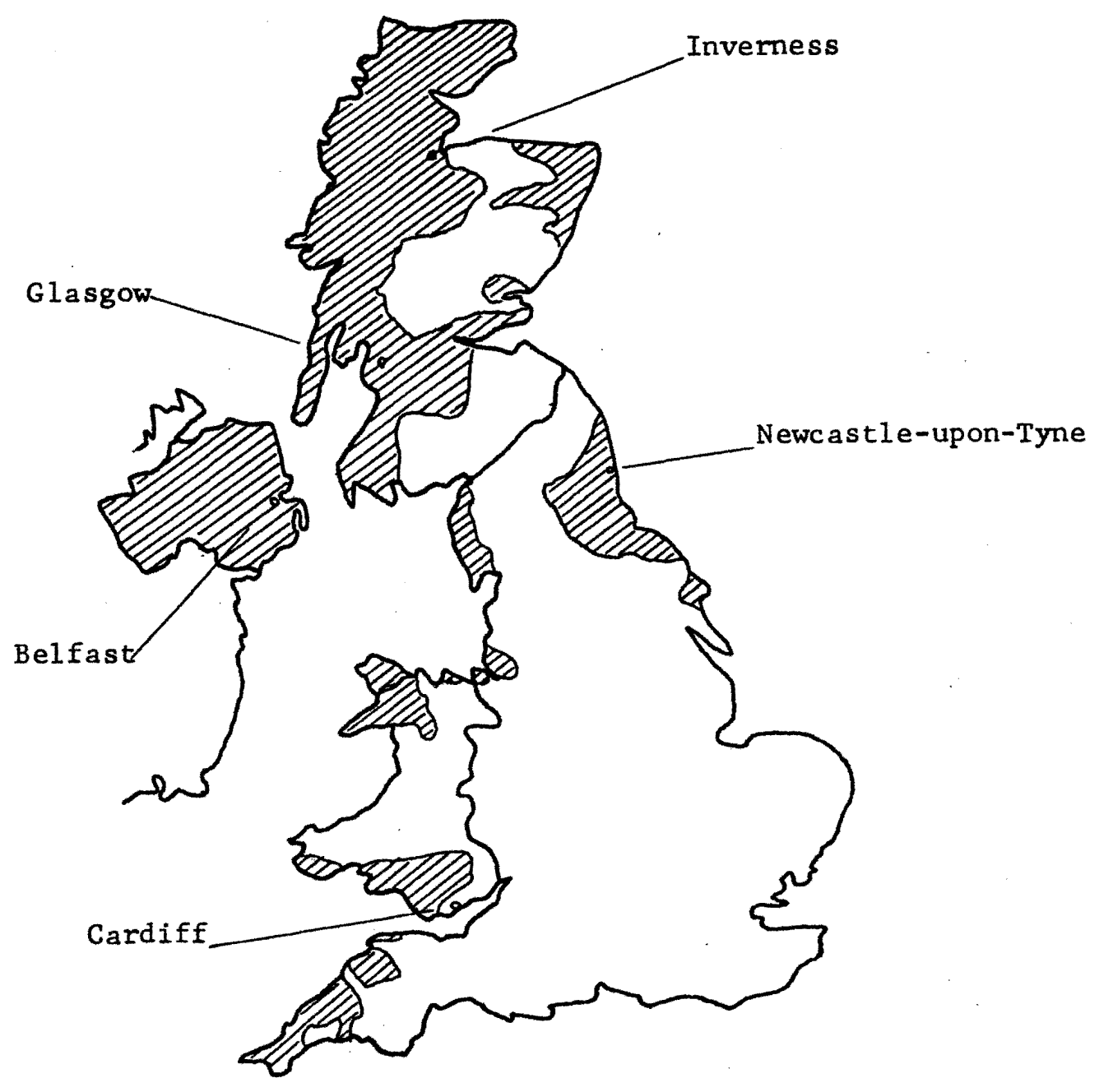

Source: Gavin McCrone, Regional Policy in Britain

(London: George Allen and Unwin, Ltd., 1969), p. 123. 
generate new growth internally. This provides a more likely solution to the problem of the small, distressed communities than trying to treat their individual ills and find a suitable economic activity to support them individually.

Special Development Areas

In 1967 when the National Coal Board program of coal mine closures was projected to be substantial, certain portions of the Development Areas were named Special Development Areas. These were the colliery (coal mine) areas affected by the plans of the NCB. Extra benefits were offered to make these areas even more attractive to industry than the DA's. (See Figure 4).

\section{Intermediate Areas}

An important new element has been introduced into the designation of areas in Britain. In 1967 a central government committee named after its chairman, Sir Joseph Hunt, proposed that Yorkshire, Humberside, and the North West Region should qualify for Intermediate Area assistance on training, factory construction, linkage roads, etc. The so-called "grey areas" did not have major unemployment but were stagnant economically and were being adversely affected by favoritism for the Development Areas, or so it was charged. Maps had shown DA's for some time as dark areas, or black areas, and the name "grey area" inplied difficulty but not in the extreme.

The areas of Nottinghamshire, Derby, and Staffordshire, where the problems were more a matter of infrastructure than unemployment, were recommended for an $85 \%$ grant for clearance of derelict land. A grant 
Figure 4. Areas in 1970.

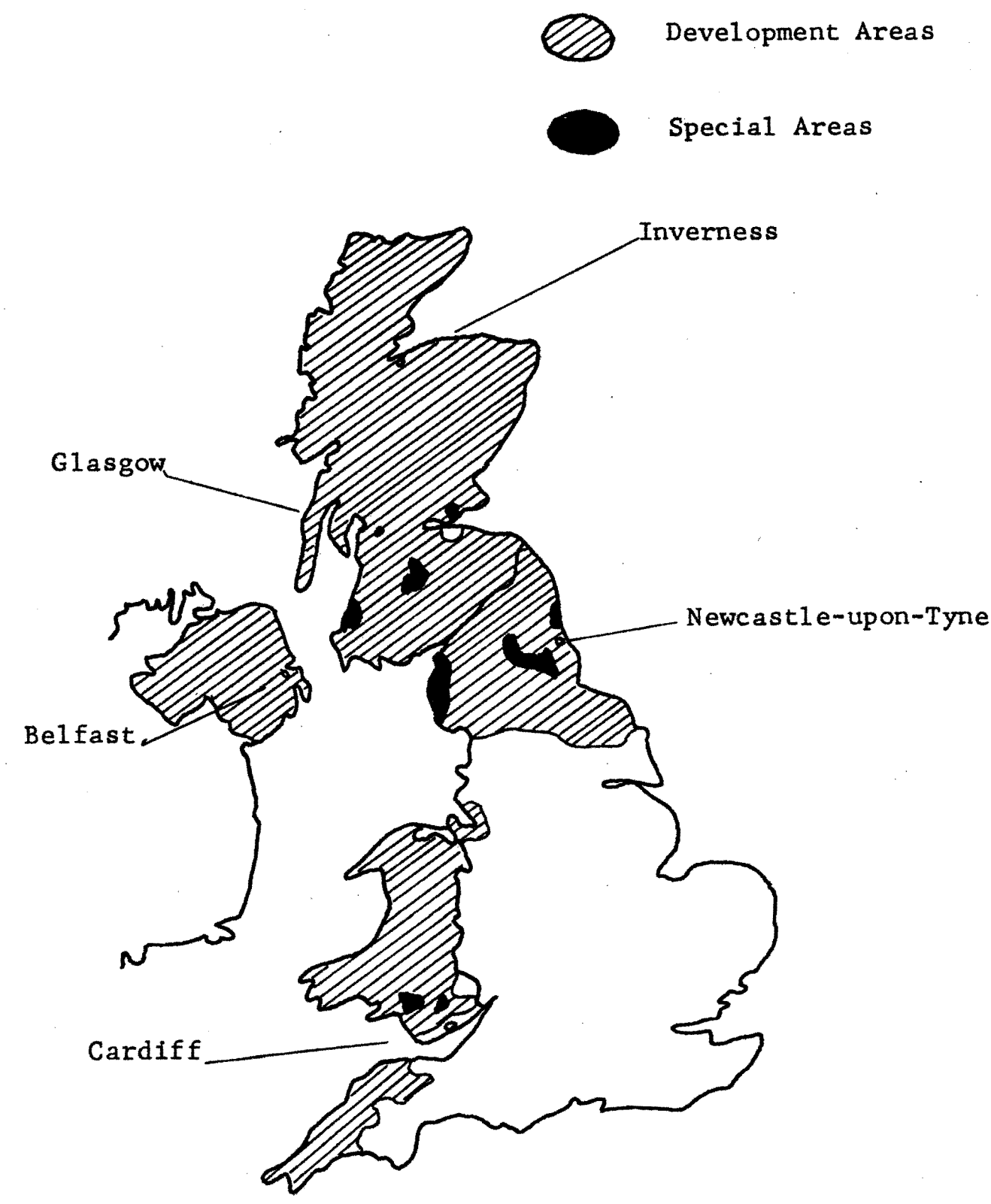

Source: Gavin McCrone, Regional Policy in Britain

(London: George A1len and Unwin, Ltd., 1969), p. 127. 
rate of $50 \%$ to $10 \mathrm{cal}$ government had been available nationally to clear 1 and which was despoiled by coal mine pit heaps, or iron and steel slag heaps, or old and decrepit industrial buildings, and these 1 ands were known as "Derelict Areas." The rate of $85 \%$ instead of $50 \%$ had been in effect in Development Areas.

A considerable change was recommended in the industrial development certificate program by raising the exemption limit to 10,000 square feet countrywide. The effect of this proposal would have been that smaller factories could be built anywhere without securing an IDC authorization and, therefore, without the central government pressure to force expansions into the Development Areas.

The government responded to the Hunt Committee recommendations by approving some of them. A $25 \%$ factory building grant was authorized, an incentive about which more will be said in later sections. However, the Intermediate Areas were not as extensive as recommended.

In addition, government-built factories (both custom and advance) were authorized for those grey areas where employment was a need. Further, the full range of training assistance was authorized. In the Intermediate and certain small areas called Special Derelict Areas, $75 \%$ grants were authorized for derelict 1 and clearance. The government kept the IDC exemption at 5,000 square feet but made it available to Intermediate Areas. The Committee had recommended descheduling of Merseyside, but the government kept it on the list. It was, coincidentally, the constituency of the Prime Minister.

\section{Political Pressures}

An official of the central government (under Labour) was quite 
candid about the special mix of economic and political reasoning behind all this. He felt there was much to commend in the designation of broad areas rather than particular communities, although he observed, "these areas are also the areas of strongest Labour support, so it is both expedient and sound to go to firm, broad Development Areas." 4 While political pressures were coming from non-designated areas, the government was also facing the prospect of closing more coal mines. Labour could not abandon the colliery areas. The Special Development Areas resulted, eligible for even more benefits than Development Areas. They have been very successful, but at the expense of the regular DA's. The North East has many economically viable SDA's but one view is that special grants are more in the nature of bribes for industrial location in parts of Wales and Scotland. The locations may not be appropriate in the long run and could become abandoned industrial facilities if the first user does not make a go of it, or if markets or technology require further investment. 5

The Hunt Committee recommended Intermediate Areas and the pressure was strong, especially to give extra assistance to renew infrastructure in the grey areas. The government felt, however, that this would be too expensive and would spread the jam too thinly. The government did not include all the areas Hunt recomnended, although political considerations were involved in naming the home areas of two of the most powerful Labour Party leaders (L. Janes Callaghan from Cardiff and George A. Brown originally from Edinburgh). Cardiff could scarcely be regarded as a continuing problem area, and it was basically unfeasible to designate just the dock areas of Edinburgh, a small enclave in a healthy 
city-region economy. These were, however, the political fiefdoms of the two leaders who had contested with Harold Wilson for Labour Party leadership, and who retained considerable power and influence.

\section{Priorities}

As the Labour Government departed Whitehall in 1970, Board of Trade priority for industrial location policy favored first the Special Development Areas, then the Development Areas, then the Intermediate Areas, then the Derelict Clearance Areas, and finally the new towns and the overspill areas. Different departments saw this a little different1y, of course. The Ministry of Housing and Local Government, for instance, would give higher priority to new towns and overspill areas. The Board of Trade believed to the contrary that if a firm can move to a new town near London, it can as well move to a Development Area like the North East. Besides, the cost of a new town is high. Why should so much be spent on a London-area new town for the sake of environment, when people badly need jobs in the North East or other Development Areas? Departments disagreed, as well, over the amount of money spent on town centers, even in the Development Areas, compared to other program measures. 'Twas always thus in big government!

\section{Government Industrial Estates}

Planned industrial districts have existed in England and the United States since the early $1900^{\prime} s$, and are "actually refinements of the Roman Empire's 'industrial estates' in which lands controlled by individuals or kingdoms were developed as centers of employment. The requirement for separation of industry and other sectors of urban 
development has been recognized for many years." 6 However, their use as a part of a nation's economic or regional development policy was new with the creation of the Team Valley Trading Estates in North East England in 1937.

The quasi-public companies operating in the Development Areas could construct factories as well as prepare land and provide for utilities and services. They could then lease (usually not sel1) to private enterprise. The trading estates were a success almost from the start. (See Figure 5).

Several factors are responsible for this rapid and continuing development of industrial estates. In the advanced countries, the scarcity of industrial 1 and near the major urban centers has long been a factor in the establishment of profit-motivated industrial estate projects; in recent years, the interest of public authorities in area and city planning, regional and local development, including rehabilitation of depressed areas, has provided growing impetus for the creation of decentralised community sponsored schemes. 7

The name "trading estates" hangs on because one of the earliest and most successful privately sponsored industrial estates, Slough Estates, Ltd., was originally intended to sell off WW I war surplus motor transport equipment on the estates. After the surplus had been sold, the site began to be developed for industrial use. At first, existing buildings were rented, and later factories were built to order, quickly and cheaply. Small industrial buildings were also built for the purpose of attracting embryo enterprises on a test, or incubator, basis.

One other type of trading estate which predated the Special Areas estates of the $1930^{\prime}$ 's were the ones included in the plans for the early new towns in Britain. Letchworth is the oldest garden city (early new 


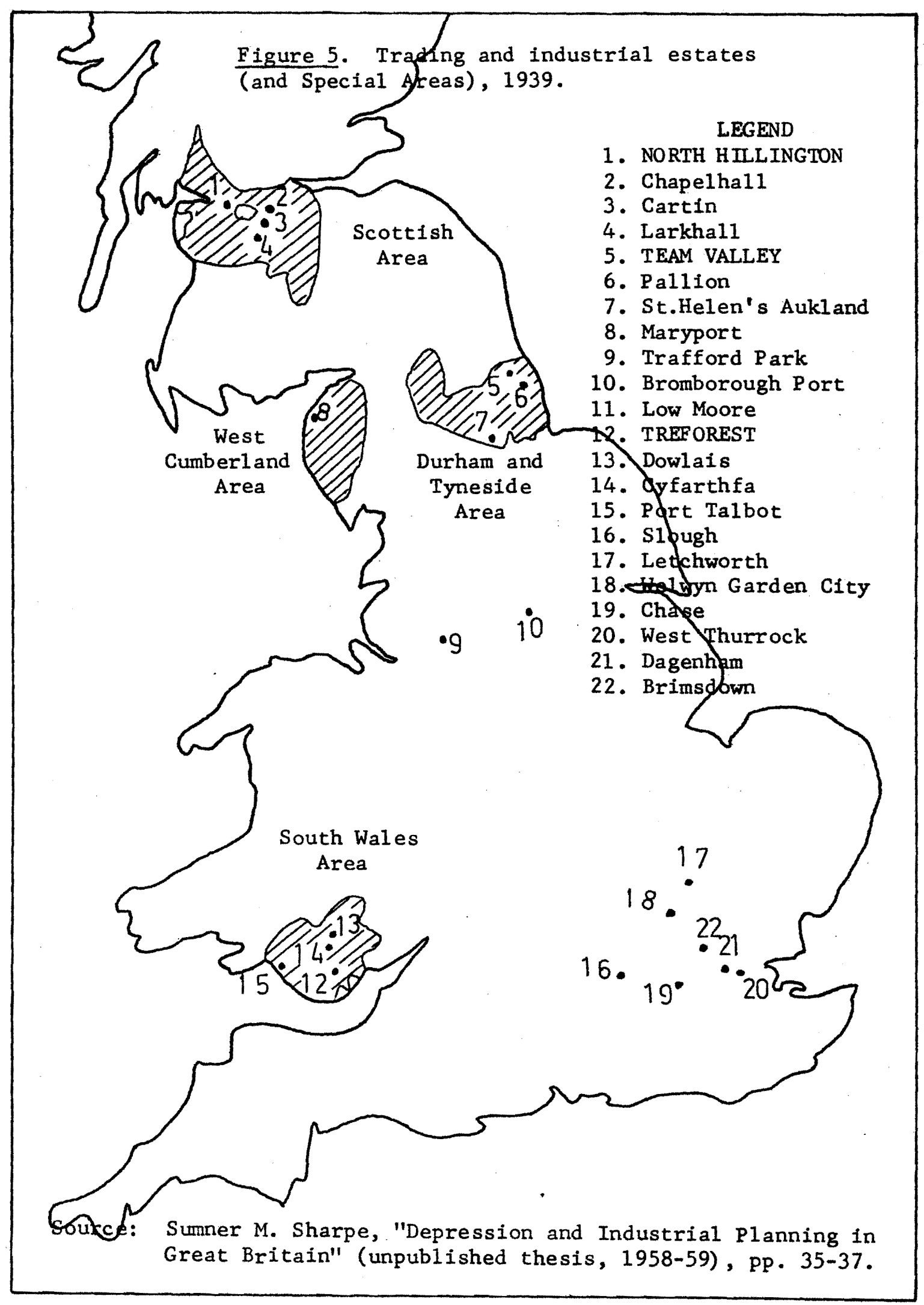


town) in Great Britain, having been founded in 1903, and Welwyn followed. These were planned communities built by limited-dividend private corporations. Their preparation of industrial 1 and to attract employment was not unlike the use of trading estates under the Depression legislation of the 1930's.

Modeled on the several successful private industrial estates, the innovative Team Valley and other industrial areas prepared under Great Depression legislation established a pattern which has persisted in its home country and has been copied in the United States and elsewhere in the world. By March, 1968, Anthony Crosland, Labour Government President of the Board of Trade, was able to report that nearly a quarter of a million people were then working in Board of Trade factories in the Development Areas. He called the Board of Trade, "one of the largest industrial landlords in the country, owning factories totalling more than sixty million square feet of which nearly $97 \%$ ' was occupied at the time. ${ }^{10}$

Factories and other buildings, either on Board of Trade estates or other industrial sites, can now be built for rent or for sale on favorable terms. They are built by the Industrial Estates Corporation of England (or Wales, or Scotland) on behalf of the Board of Trade.* Northern Ireland has a comparable program. New factories can be built for a particular firm or in advance of securing tenants.

* The former name of the government agency administering the program was the Board of Trade, a name which tends to confuse Americans who assume that it was some sort of industry association. It was, however, an agency on the order of the U. S. Department of Commerce. It is now called the Department of Trade and Industry and has fallen in status to a Division of the Ministry of Industry under the Conservative Government. 


\section{Control of Industrial Location}

The most distinctive method of regional economic development in Britain vis a vis the United States is the permit system for the construction of new industrial and office structures, by which location of economic activity is substantially influenced. The developer must apply for an I. D. C. (Industrial Development Certificate). There are exemptions for structures under 5,000 square feet for factory space and 10,000 square feet for office space, except in Greater London where only the very small ( 3,000 square feet) office is exempt. If the Board of Trade ascertains that the applicant could as well build the factory or office structure in a Development Area, or in another type of priority area, it will refuse to issue the I. D. C. The sometimes subtle, sometimes not, process usually prompts at least a token effort on the part of the larger companies to locate in the Development Areas.

Until 1965 the working assumption had been that most employment is directly or indirectly related to production industries, so that control of factory buildings location would obtain results without requiring complete bureaucratic control of all economic decision-making. However, the service sector of the economy is expanding more rapidly than production of goods. The changing character of economic activity led to the passage of the Control of Office and Industrial Development Bill in 1965, thereby adding office to factory controls.

Nothing like the I. D. C. system exists in the American economic development program, in which all the techniques are of the incentive variety rather than restrictive. The only restrictions on location in this country relate to defense considerations, or political pressures, 
or both, which sometimes result in preventing the location of a plant in the area of management's first choice. Of course, state and local controls on pollution and land use have some effect but are not intended to positively affect the distribution of industry. We are hearing some discussion of curtailing the growth of our population in industrially impacted areas, but no national legislation to date.

The effectiveness of the British control measures depends upon the resolve with which they are administered. An examination of this question provides a perfect illustration of the need to look behind the words of much legislation to see how it actually is applied. There have long been complaints in the Development Areas that the Board of Trade was too soft on issuing I. D. C's in the London area. D. A.'s, as we have noted, are almost entirely Labour voting areas, so it is not surprising to find the Labour Party championing the vigorous application of the system of controls intended to slow down growth in South East England, largely Conservative in political preference. But what does the reoord show?

The legislation itself was a product of the Barlow Commission appointed by a Conservative Government, deliberated upon by a Coalition (war-time) Government, and passed by a Labour Government in 1945 and 1947. While the I. D. C. system was employed during the years of Conservative Government in the 1950's, it was less vigorously applied than it had been under Labour. Revival of interest in the early 1960's resulted in some pick-up in firmness.

However, the Conservative preference was for incentives, not controls. It was left to the Labourites to revitalize the system in 
1965. A Special Issue of Economic Brief, published by the Labour Party as a warm-up for the 1970 election, states its claim to vigor in use of location controls. (See Table VI). Because of my work in the Northern Region, I was most interested in the following excerpt:

One thing is clear; Labour's regional policies... have brought improvements and without them prospects would indeed be grim.

The North

In $1959,25 \%$ of Durham's male employees worked in coal. This year the figure is $13 \frac{1}{2} \%$. Coal, steel, shipbuilding and heavy engineering still provide a quarter of male jobs in the region but stricter operation of the I. D. C. (Industrial Development Certificate)s System, and bigger financial incentives to industry, have brought in newer industries. I. D. C.'s were issued for $34 \mathrm{~m}$. sq. ft. of industrial floor-space in the four years 1965-8 compared with $22 \mathrm{~m}$. sq. ft. in the previous four years.11

But counter pressures were at work, even within the Labour

Government. To the chagrin of many in the Party, full application of controls had to be modified by the paramount need to meet the balance of trade crises which plagued Labour reformers through nearly all of their tenure in office from 1964 to 1970. A Board of Trade official told me, with some distaste, that it seemed as though the larger companies needed only to plead that removal to Development Areas would diminish their export position, or that they might be forced to locate on the continent instead of in Britain (especially the American companies). These two fears were often sufficient for Treasury and other officials to override the Board of Trade policy objective of favoritism to the Development Areas. ${ }^{13}$

As an aside, this same official was ruefully forecasting further trouble for the Board of Trade IDC program. As a result of the Labour Government reorganization plan of the autumn of 1969 , the Board of 


\section{TABLE VI}

ESTIMATED ADDITIONAL EMPLOYMENT FROM IDC APPROVALS 12

Annual Averages

\begin{tabular}{lrr} 
Region & $1956-64$ & \multicolumn{1}{c}{$1965-69$} \\
\cline { 2 - 3 } North & 9,066 & 20,780 \\
North West & 16,040 & 21,720 \\
South West & 6,040 & 7,840 \\
Great Britain & 97,350 & 127,660
\end{tabular}

Trade had been placed in the Ministry of Technology, from which often had come the most piteous cries in behalf of industries which were being pressured to expand into Development Areas. The Ministry of Technology was organized to serve industrial boards, and hence was closely linked with the industries, not unlike the Business and Defense Administration in the U. S. Department of Commerce.

On the office development program there may be more agreement. Critics fault its administration for lack of effectiveness. The problems of the Development Areas, it is to be noted, are only partly due to their over-reliance on basic heavy industries. A corollary of that problem is that the D. A.'s lack white-collar jobs--the most rapidly expanding sector in the national economy.

The South East is receiving a preponderant share of this growth. For instance, $18 \%$ of the labor force is in clerical occupations, compared to $12 \%$ in the balance of the country. The pressures to permit office structures in areas around London are particularly strong. Moreover, few "advance offices" have been built. Finally, primary attention is in attracting industrial payrolls which in itself encourages further imbalance. 
Ray Thomas says that on office development the government "is waving the stick, but seems to have forgotten the carrot." He charges that the "main weakness of the Development Area policy is not the size or nature of the incentives but the fact that they are designed to influence the location of factory and not office employment. They are helping to perpetuate the differences between north and south." 14

Part of the problem is that decision-making in the private sector is concentrated in London and, with normal inertia which encourages growth in-place, the Development Areas must face both overt and covert opposition. "...part of this reluctance is attributable to the fact that many of their employees don't want to move far either. "15

It is apparent that considerable judgment is and must be exercised in the administration of the I. D. C. program, and whether application is strong or weak is partly in the eye of the beholder. Local officials in North East England appear to believe that the Board of Trade has been exceedingly helpful and that the I. D. C. system is basic to the success of the various programs of incentives offered to attract industry.

\section{A Case Study}

Additional insight into the system can be provided by talking with company and local government officials about Ever Ready Company, Ltd., which built a plant at Tanfield Lea, near Stanley in County Durham. They agree that initially the company contemplated a small plant on five acres to employ no more than 300 employees. Once they got to the area and began their planning, they decided it was too good a deal to pass up, bought 60 acres, and put up a much larger plant. 
The installation cost 15 million pounds and is expected to employ 1,700

at capacity. The company candidly outlined its planning process:

At the end of 1965 it became apparent that a further battery assembly plant would soon be required and plans for it were put in hand. The Board of Trade urged that we should consider going to a Development Area rather than setting up a factory in our traditional manufacturing areas, South East England and the Midlands.16

The company was looking for a small site for a battery assembly

factory, but the distance from supply factories posed an obstacle.

Officials reviewed the project and "assembled the following facts:"

(1) With world demand for batteries increasing at the rate of about $15 \%$. per annum,... we should be requiring still further battery assembly factories over the next decade.

(2) We were reaching...the capacity of some of our component and raw material processing plants, and new factories for them would be required.

(3) It was likely that Government policy would persuade, if not force, us to set up these factories in Development Areas.

(4) The financial advantages of operating new factories in Development Areas were very real.

(5) Our study of the Tanfield Lea area had shown the need there for employment opportunities for the many people made redundant by pit closures.

(6) The technical schools and colleges in the district were turning out well-trained people who... were not being used to the full extent of their abilities.

(7). A site of 60 acres, at a reasonable price, was available at Tanfield Lea.

(8) The North East region of the Board of Trade, Durham County and local autoorities, showed us not only a welcome, but they were prepared to go to almost any length to satisfy our requirements.

The idea of an integrated plant sufficient to meet our increasing needs for the ' 70 s thus developed. 17 
Grants to Industry

The type of grant available to industry in Britain for the cost of expanding or moving to a Development Area is virtually unknown in the American program. Only under extremely odd circumstances does a profit-making enterprise receive a direct grant of assistance in the U. S., other than tax advantages, whereas direct grants are the mainstay of the British incentive program. Grants are made to industry for a variety of purposes, especially to stimulate modernization, the lack of which has been noted and deplored for some time. Investment grants are payable to businesses anywhere in Great Britain for new machinery and equipment in manufacturing, extraction, and construction industries.: Regardless of industry, grants are available for computers, ships, and hovercraft. Assistance is calculated as a percentage of the capital cost of providing the assets concerned, and their purpose is to stimulate more efficient production facilities. Antiquated plant and equipment has been a problem for the British in competing with the post-war rebuilt German industrial structure, and the fastmoving industrial economies of the United States, Japan, and some other advanced countries.

The use of especially favorable grants to steer British industry to Development Areas now has had a long and honorable history. The investment grant rate for $\mathrm{DA}^{\prime} \mathrm{s}$ is double the national rate of $20 \%$. In 1967 and 1968 the rate was temporarily as high as $45 \%$, but is now $40 \%$. In addition to the investment grant program under the Industrial Development Act of 1966, building grants are available under the Local Employment Acts of 1960-1966. Excluding the cost of the site, such 
grants are available for the purchase of a new building (not previously occupied) or the construction or extension of a building. The normal rate is $25 \%$, but where there are special problems involved in setting up for the first time in a Development Area, or at a considerable distance from the firm's existing facilities, the rate can be $35 \%$ of the cost. In Special Development Areas (coal-mine closure areas), the project could qualify for a $35 \%$ building grant plus a 1 oan at moderate rates for the balance of the building costs. The $25 \%$ grants are al so available now in the Intermediate Areas. An independent body of business and professional men on the Board of Trade Advisory Committee (BOTAC) are consulted to ensure that the applicant has a reasonable prospect of succeeding in the enterprise. Small projects (under $\$ 24,000)$ are not normally referred to the BOTAC.

Building grants were intended initially for manufacturing facilities, but are now available (since July, 1968) for service industry projects providing 50 jobs or more. This was particularly significant to tourism in the DA's, most of which are in outlying areas beyond the heavier visitation patterns.

In the SDA's, new projects can receive operational grants for three years, normally at the annual rate of $10 \%$ of the non-grant expenditure on eligible buildings, plant and machinery.

The historic development of incentive grants for new and expanding industry began with the Depression industrial lending experience. A shift from loans to grants came with the 1945 Act which provided for both loans and grants to industry, on advice of an independent Development Areas Treasury Advisory Committee. It was expanded in the 
1958 legislation and the consultative body changed in 1960 to the BOTAC. The 1960 Local Employment Act also provided for a new building grant to industries wanting to build their own factory. A grant could be made for $85 \%$ of the excess cost of the premises over its open market value at the time of completion. In practice these grants averaged $17 \%$ of the cost. ${ }^{18}$ In a depressed location, market value of a new factory might be substantially under its cost, but this complicated standard was changed by the 1963 Local Employment Act to the simple $25 \%$ of the cost of the new buildings or extensions of existing buildings.

\section{Loans to Industry}

Government lending to industry in the U. S. genera11y has been acceptable public policy since the Reconstruction Finance Corporation of the Hoover Administration in the early days of the Depression. Since that time, we have had 1 ittle reluctance to authorize loans to industry for special purposes. Although the United Kingdom has since outdistanced the United States in rendering assistance to lagging local economies, Britain experienced more early reluctance to resort to government industrial loans. When the 1934 Special Areas legislation was formulated, the attitude of Parliament was expressed in the limitation that no special funds could be used to help finance private enterprise.

In 1936 the line broke and the Treasury was authorized to enter the loan business by guaranteeing loans made by the Special Areas Reconstruction Association, Ltd. (SARA). The 1937 amendment authorized a direct loan program. The model and predecessor for modern loan programs for industry in $\mathrm{DA}^{\prime} \mathrm{s}$ was the 1945 Distribution of Industry Act 
which authorized the Board of Trade to make loans and grants to industry. Today there are a variety of loan services available.

A small loan program is operated by The Council for Small Industries in Rural Areas (1ong-term, low-interest rates, up to $80 \%$ of cost, for firms employing fewer than 20 skilled persons in areas or towns of not more than 10,000 population). Priority is given to export industries, which is a priority of all British assistance to industry, and can be given tourism enterprises. Loans and grants more commonly go to the tourist industry now than in the past in those areas where tourism seems the most likely economic future. ${ }^{19}$

Currently the Industrial Development Act of 1966 authorizes loans for the purchase or construction of facilities. Alternatively, the Board of Trade may provide the buildings or a building grant. In the Special Development Areas loans can even be made to supplement a building grant. Additionally, loans can be made for the purchase of machinery and equipment (excluding the amount of any investment grants made) and for working capital. Loan repayment can be long-term and the interest rate is moderate.

The feasibility of a project is examined by the BOTAC (Board of Trade Advisory Committee) which must give its approval, but the final determination is made by the President of the Board of Trade. Processing takes place initially in the regional office of the agency but is finalized in London. This system is comparable to that in the United States. Applicants are expected to put up some of the financing and to have a reasonably balanced capital structure without too much reliance on debt financing from any source. 20 
There is some difference between loans made by the Board of Trade under the Industrial Development Act and those made under the Local Employments Acts of 1960 to 1966. Under the former, the BOT makes incentive loans available to all qualified applicants in the designated areas. Under the latter, assistance is available only according to the amount of employment provided.

Comparison of U.S. and U. K. Loans

In the United States, the employment ratio--dollar assistance to jobs provided--is also a prominent factor in the processing of any project. The Economic Development Administration goes to great lengths to assure important economic impact before it even permits an application to be made for assistance.

Programs in the U. S. are seldom as generous as the British, but the Americans often permit a heavier debt structure. The tendency in the last two or three years in EDA, however, has been to be more conservative in its lending standards. Conservatism was made politically easy by the sharply proscribed program resources, necessitated by Vietnam priorities in government spending. If the fully authorized amount were available for business loans, lending standards might have to be loosened in order to place the money.

Two other bases for comparison of the U.S. and U. K. programs are (1) the success ratio on repayment of loans and (2) the speed of processing applications. No statistical information could be obtained on the success ratio of the British effort. It is not easy to come by such information in this country either, partly because the record is rather poor. As many as one-third of the loans made by the Area 
Redevelopment Administration from 1961 to 1965 have ended in trouble. Judging from the standards apparently employed, the record has not been nearly that sad in Britain. British standards appear to approximate the lending requirements of the Small Business Administration in the United States, which has been a collateral-oriented, bank-committee-type program, in contrast with the deliberate risk-taking approach of the Area Redevelopment Administration. The Economic Development Administration, which succeeded ARA in 1965, has retreated from the more speculative stand of ARA, but continues to try to judge risks rather than rely heavily upon collateral lending methods.

Well known to applicants and practitioners in this country have been the 1 ong, 1ong delays in obtaining a loan after application has been made. The time element has run on the order of a year in the ARA-EDA program, often longer, and quite an extended time for the smaller direct loans offered by SBA as well. Very little is available in written form on this aspect in either country, although EDA now publishes the average number of days it takes to process 1 oan and grant applications.

One study in Britain did come to my attention. The North East Development Council (made up of local authorities in County Durham and Northumberland) surveyed the experiences of some North East firms in applying for government loans and grants.

6. In particular, the average time taken by B.O.T.A.C. in processing applications is misrepresented to firms when they first make their inquiries. In the past they were told 3 months, and recently the figure was raised to 6 months. However, the average in our sample of 29 applications for Building Grants is fractionally over 12 months. There was one application for a loan that took less than 6 months and 5 which took up to 18 months. 
10. B. O.T.A.C. have recently stated that much delay results from incorrect completion of forms. The questionnaire did not ask for information on this point, but the survey shows in a general way that much of what goes wrong could be put right at a much earlier stage. It is al so possible that B.O.T.A.C. could devise better means of obtaining the information they require by follow-up. The histories of the applications we have seen show intervals between requests for information received from B.0.T.A.C. which are inexplicable if there is a real determination to process each application as quickly as possible. Rapid processing of applications is essential for a Development Area with high unemployment. 21 .

A general statement criticizing the time 1 ag in processing applications could be devised that would have equal validity on either side of the Atlantic and in which the initials EDA, ARA, and BOTAC could be interchangeable. EDA in fiscal year 1969 claimed a business loan average processing time of 195 days, its best record in several years. 22

It would be fair to assert that most of the difference between the programs of the two countries is not in approach, but more in quality and quantity. Both provide aid to industry in the form of loans, but the Americans fail to attract many customers because of sticky administration, shortage of funds, and lack of a supporting grant program. British industry is more willing than American businessmen to countenance bureaucratic processing of applications because, at least in part, the benefits are much more material, including as much as half the capital cost in the form of grants.

In the study of the experiences of North East firms, a point was made which has some significance in comparing different forms of incentives offered. The survey noted that the investment grants had significant processing advantages. 
Our survey shows that the relatively new investment grant procedures are regarded as efficient and predictable in outcome. The Regional Employment Premium, (not discussed In our survey) will also be an automatic thing. This growth of predictable assistance scemes will have the effect of showing up the complex procedures of B.O.T.A.C. in an increasingly unfavorable light. ${ }^{23}$

The investment grants are available to all firms under circumstances which can be quite simply ascertained. They do not depend upon a government assessment of entrepreneurial skill, market analysis, and detailed evaluation of financial feasibility of the enterprise. Processing of loan applications is dependent upon securing the signatures of Civil Service officials. They must certify that the investment is good, and that the government is protected. This cal is for sagacity and courage, or alternatively, for exhaustive probing and compliance with detailed regulations. In the absence of the former, most government programs rely upon the latter. On the other hand, payments uniformly available to run-of-the-mill entrepreneurs can be predictably administered by making several key checks and the results are likely to be no worse than the law of averages.

Predictability is an important factor in how well the government incentives attract the quality of industry which the Development Areas need. If a company cannot feel reasonably certain of success in obtaining favorable loans or grants, it can be bad business to spend a year waiting for an answer. This is especially true of the more desirable, fast-growing industries. A "second-best" financing plan can produce more profit if it is quicker and more certain in getting production to meet emerging market opportunities. "Unpredictability" is the greatest single handicap in the American effort to steer the 
aggressive growth-type company into designated areas.

\section{Tax Concessions}

Now of minor importance, tax concessions were the earliest type of assistance to the areas suffering regional differences in unemployment. In 1929 an industrial derating program was tried, by which factories were charged only one-quarter of the going tax rate, but this measure "was of little help to towns such as Jarrow, where the rates in 1935-6 were $19 \mathrm{~s} 6 \mathrm{~d}$ * compared with $13 \mathrm{~s} 10 \mathrm{~d}$ * in Newburn." 24

The 1937 Special Areas legislation introduced rental deductions, and property and income tax rate concessions for a period not exceeding five years for new firms, and provided that firms in the Special Areas could be exempted from the new National Defense Tax which started in 1937. These were the first tax incentives on a regional basis, but after the war they were not employed again until the Conservative budget of $1963 .^{25}$ The Minister in this instance was Reginald Mauding, who is again in the Cabinet.

The Finance Act of 1963 introduced "free depreciation" for writing off certain machinery and equipment. The incentive provision was a concession for both the Development Districts and designated overspill areas (particularly around Birmingham, Manchester, and Glasgow). This tax break was replaced, however, by the 1966 Industrial Development Act, the present system of investment for manufacturing, extractive, and construction industries.

${ }^{*} 19$ shillings, 6 pennies and 13 shillings, 10 pennies. 20 shillings to the pound, 12 pennies to the shilling--1971 rate of exchange, $\$ 2.40$ to the pound. 
Investment in production industries was lagging as the service industries became increasingly profitable early in the decade of the 1960's. To make investment in production industries more attractive to Investors, the Labour Government introduced a Selective Employment Tax (SET). An employer in manufacturing was able to claim back the full value of the tax paid on his employees, plus a bonus of $7 \mathrm{~s} 6 \mathrm{~d}$ per man per week, with small amounts for women and minors.

To adapt this industrial incentive program to regional purposes, the Regional Employment Premium (REP) was introduced in 1967, by which manufacturers in Development Areas could claim an additional 30s per week per man ( $\$ 3.60$ at 1971 rates of exchange). ${ }^{26}$ The $7 \mathrm{~s} 6 \mathrm{~d}$ SET payments were abolished at the time of devaluation (November, 1967) except that they were retained in Development Areas, and in 1968 the SET rates for $\mathrm{DA}^{\prime}$ 's were increased $50 \%$. The SET payments were dropped altogether in April, 1970, leaving the REP rate at 30 s per man. 27 These payments amount to a labor subsidy to the Development Areas, of course. But the subsidy is self-supporting in terms of cost to the government because it is a tax collected nationally and redistributed according to industrial activity and region. Notable in the Conservative election program in 1970 was the promise to abolish the Selective Employment Tax.

As for tax incentives in general, the viewpoint of the Labour Government, shared perhaps by most students of incentive programs, was that first a company must make a profit before tax incentives are of much benefit. The Labourites concluded that the investment grant system would influence investment decisions far more certainly than the 
depreciation allowance system, and therefore, made the substitution in the 1966 legislation. Most of the tax advantage programs have been supplanted by direct assistance programs. Whether the Conservative Government will agree is doubtful.

Little recognized as an industry incentive, but an exceedingly Important tax benefit to Development Areas, is the rate of equalization measure which redistributes revenues among local authorities approximately according to need. Typically, Development Areas in both the U. S. and U. K. are the least wealthy and have the greatest unmet needs for community facilities and services. The share of central (federa1) program resources going to meet these needs is significantly greater in Britain, and the central government leveling of local tax revenue means relatively lower taxes for industry locating in $\mathrm{DA}^{\prime} \mathrm{s}$.

Finally, taxing powers have been used in recent years to stimulate training. Industrial training boards have levied taxes on individual industries and redistributed the receipts to firms inaugurating approved training programs. The firms with vigorous training programs can receive more than they pay out for the services of training manpower for industry. Companies without their own training programs benefit by sharing in the trained manpower pool, or are penalized for not doing their share.

\section{Education and Training}

The term "the Establishment" derives from the Church of England, long a power in the English ruling class. The term more than anything else now means those of the preferred public (meaning private, really) school background--Eton, Harrow, Oxford, Cambridge. The Duke of 
Wellington's famous quote that the Battle of Waterloo "was won on the playing fields of Eton" incorporates the notion that the games, cold water baths, floggings, Latin, and Greek enhances the natural fitness of the well-born to lead lesser Englishmen in all endeavors. 29

The British educational system, which for many generations had served to perpetuate class divisions and enthrone amatuerism in seats of power throughout the nation, came under heavy attack in the $1960^{\prime} \mathrm{s}$. There began a restructuring of the state schools along more democratic lines, a widening of opportunity for university study, and everywhere a new and positive orientation toward applied science. ${ }^{30}$

Recognition is growing that Britain trails the United States and other industrial nations and cannot catch up without a greatly increased output from its educational system. Emphasis on the humanities has left Britain short of engineers, scientists, and technicians. Reliance upon upper class generalists for the Civil Service Administrative Class and for top business leadership has slowed British response to technological competition and to scientific management techniques.

Official Labour Party policy was to convert the total public school system to comprehensive schools and to modify the system of educational selection called "the elevenses" (tests given at eleven years of age). On the results of the eleven-plus examination, the mechanically minded $5 \%$ were sent to technical schools, the top $20 \%$ to scholarly grammar schools, and the remaining $75 \%$ to "secondary modern" schools. The latter "having none of the best minds" among the student body, or faculty, often became semi-vocational institutions where children were dumped until the legal school-leaving age of fifteen. The Labour Government declared war on the eleven-plus in 1964 when it 
came to power. While British schools are run by local authorities, the central government pays most of the cost of construction. The Education Minister was reluctant to approve any new plans except where a comprehensive system had been adopted. The "comprehensive" school is a postWorld War II development in which grammar, technical and secondary modern schools are under one roof. ${ }^{31}$

The Conservative Party and traditionalist educators are building a backlash in protest against the lowering of educational standards which has produced the "great" of Britain. Circunstances differ, but the rhetoric is the same in the debate in the U. $S$. over the admission of the "underqualified" to universities. As a guide said one day as he led a tour in London, "at least education in our country is assured to everyone who is worthwhile." Aside from the class-oriented overtones, what he meant to say was that financial assistance is available to all students who qualify academically. Parents must meet a "means test" and pay part of the expense if they can, but pub1ic authorities underwrite all university expenses, including a vacation allowance. But English public schools continue to educate only $2 \%$ of England's young men.

An adult education system has been developed throughout the country because of the shortcomings of the day-school system, particularly as the result of the early school-leaving age. ${ }^{32}$ To the American "poverty-warrier," however, it comes as a revelation to discover that actual illiteracy among the native born is almost nonexistent in England. Training programs seldom need to start with what we call "G. E. D." classes (the test for general education equivalency 
to formal education). Except among the immigrant population, there is much less illiteracy than in the United States, so there is less need for adult basic education. Training programs can concentrate on skills training. The author was told by a training official that if some academic brush-up was in order that a small amount of it could be provided, but rather informal1y.

The Department of Employment and Productivity has established Government Training Centers around the country, most of the more recent ones being in Development Areas. Institutional training is provided for skills needed in substantial supply, including a number of trades long considered apprenticeable (primarily to be trained on-the-job). The Centers concentrate on programs they can anticipate using for five years or more. Some of the apprenticeable trade programs, such as electrical, plumbing, and carpentry, run six to twelve months and produce manpower with the technical training to become good craftsmen within a year or so on the job. This cuts total training time to about one-half that required in the United States. The government manpower programs in the U.S. feature a greater variety of training but of lesser quality than in England, if my observation based on a brief visit can be trusted.

Grants are also made to employers by the Department of Employment and Productivity toward training costs. These grants were doubled in October, 1967 , to 10 pounds for male trainees and seven pounds for female. 33

Further grants are now available to help firms establish their own training schools. Up to $70 \%$ of the capital cost of required 
machinery and equipment is provided for off-the-job, semi-skilled training. Instructors from the DEP are available to launch the trainIng programs on company premises for companies in the engineering fields. 34

Since December, 1967 , grants have been offered covering $60 \%$ of the cost of providing new off-the-job training for craft and technician training. Alternatively, a grant of 100 pounds is offered for each year up to five years for every trainee additional to the number employed at the end of 1967 (average of the last three months). 35

The full range of training benefits are now also available in the Intermediate Areas.

\section{A Case of One That "Went Wrong!"}

The picture of program results would not be complete without some feeling for the risks which have to be run in trying to stimulate new industrial growth. Writing about the towns, Ray Thomas relates an incident in the history of the Scottish new town of Glenrothes which admirably illustrates a number of program hazards. The following are excerpts from his narrative:

Cadco Developments was a company registered for tax purposes in Curacao which derived most of its funds from the earnings of the actor George Sanders. The main manufacturing subsidiary which was to set up in Glenrothes was the Royal Victoria Sausage Company which was already engaged in making sausages in Sussex and which was run by a persuasive character called Denis Loraine, and by an ex-lieutenant-colonel, solicitor and taxation advisory, T. C. W. Roe, CBE. Sanders, Loraine, and Roe all met members and staff of the Corporation and made plans to take over 40 acres of the town and to invest three million pounds in 1 and, buildings and equipment.

Lord Hughes, the Chairman of Glenrothes Development Corporation, said that the new enterprise was the biggest thing in Scotland since the advent of the motor industry. 
A county councillor said that there was no reason why Glenrothes should not become the workshop of Fife. There were banner headlines in the press: 'Jobs for 2,000 in Film Star's Plan', 'Fife Jobs Boost', 'Sophia McLoren and all this!'

The Corporation didn't closely examine the mouth of their gift horse, partly because they assumed that this would be done more efficiently by the Board of Trade. The Corporation didn't have any special resources for this kind of examination and they knew the Cadco would be investigated in order to qualify for the standard 25 per cent building grant available under the 1963 budget.... In fact Cadco didn't apply to the Board of Trade until October 1963 and the Board of Trade didn't prick the balloon by refusing a grant until July 1964.

Cadco not only gave a false impression of their financial resources but also concealed the fact that Royal Victoria Sausages had yet to make a significant profit, and when Brigadier Doyle, Glenrothes' General Manager, visited the Partridge Green factory he was told that he was only seeing the day shift at work. According to the subsequent Board of Trade enquiry the whole exercise was an attempt 'with the aid of public loans and grants...to obtain a building profit...to attract other capital, possibly by public flotation.'

The contractual position is complicated. But work started in July 1963 with a so-called subsidiary Cadco Building engaged on the construction of piggeries and offices and the modification of existing advance factories with the Development Corporation paying Cadco Building against certificates from independent quantity surveyors which were issued fortnightly. This was part of an arrangement by which the Corporation would loan 95 per cent of the cost of 1 and and buildings to Cadco Developments repayable over 20 years at $7 \frac{1}{2}$ per cent. Cadco obtained the rest of their financial needs with an overdraft from the Royal Bank of Scotland and from a number of individuals who had succumbed to the infectious optimism of Loraine or Roe.

Glenrothes Development Corporation didn't lose much financially; they were just landed with a rather unsaleable product --a collection of badly designed piggeries. And even piggeries can be modified to suit the needs of other industry. The buildings constructed for Cadco served as advance factories to attract new employers and nearly all of them are now occupied.

The affair throws an interesting light on the interaction between private industry and finance and governmental 
institutions. Cadco were able to obtain money from a variety of private sources on the basis of a promise of success, and who knows, if they had also been successful in getting a Board of Trade grant, whether they might have actually become a profitable and respectable company. The investigator for the Accounts Division of the Board of Trade who considered Cadco's application concluded that the project was over ambitious and that there was no assurance that the shareholders would provide the necessary funds, but the investigator is not the decision maker in these matters. He actually reports to an advisory committee of independent business and professional men which has the power of veto, and in this case it took a subcommittee and two full committee meetings to reject the application. 36

\section{Late Breaking Developments Under The Conservatives}

The Conservative Party coming to power in 1970 made some changes in emphasis, al though falling short of their campaign promises. They had promised to abolish the Selective Employment Tax, for instance, but instead hal ved the rates in 1971. Over-all expenditure on regional incentives was reduced in 1971, but as a part of a growth budget in 1972 , free spending was restored. 37

As of March, 1972, it was announced that the following incentives would be available to depressed regions: ${ }^{37}$

Intermediate Areas: Building grants of $20 \%$.

Derelict Areas: Building grants of $20 \%$ for two years only.

Development Areas: Grants of $20 \%$ on buildings, plant and machinery.

Special Areas: Grants of $22 \%$ on buildings, plant and machinery.

The grants would be paid as a matter of right, not related to employment, and would be available for modernization as well as new projects. Selective assistance under the Local Employment Acts would be more freely available for modernization as well as new jobs, and 
also in certain cases to industries with nationwide problems outside designated areas (shipbuilding, for instance). Training and resettlement grants were increased. 37

An announcement made in 1971 that Regional Employment Premiums would be stopped as of 1974 was rescinded by a decision in March, 1972, to phase out REP at some unspecified time in the future. 37 
${ }^{1}$ Sumner M. Sharpe, "Depression and Industrial Planning in Great Britain" (unpublished thesis, 1958-59), pp. 35-37.

${ }^{2}$ Gavin McCrone, Regional Policy in Britain (London: George Allen and Unwin, Ltd., 1969), p. 107.

Ibid., pp. 124-26.

${ }^{4}$ Interview, an official, Distribution of Industry Division, Board of Trade, London, October, 1969 (name witheld to avoid possible embarrassment to the interviewee).

${ }^{5}$ Ibid.

${ }^{6}$ Henry Bistwick, Jr., "The Industrial Park: What It Is-and Isn't." Nation's Business, September, 1969 (reprinted in "Economic Development," Vol. 6, No. 11, November, 1969, by Economic Development Administration, U. S. Department of Commerce).

7 Department of Economic and Social Affairs, United Nations, Industrial Estates: Policies, Plans and Progress (New York: United Nations, 1966), p. 4.

8 Sumner M. Sharpe, p. 8 .

${ }^{9}$ Ibid., p. 3.

${ }^{10}$ Anthony Crosland, "A Progress Report on the Development Areas," (Extract) Board of Trade Journal, March 29, 1968.

11 "Labour's First Five Years--The Quiet Revolution," Economic Brief, Vol. 2, No. 10, Special Issue (London: The Labour Party of the United Kingdom, 1970), p. 11.

12 Ibid.

${ }^{13}$ Interview, Board of Trade official, London, October, 1969.

${ }^{14}$ Ray Thomas, Aycliffe to Cumbernauld: A Study of Seven New Towns in Their Regions (London: Political and Economic Planning, 1969), pp. 949-50.

${ }^{15}$ Ibid., p. 950.

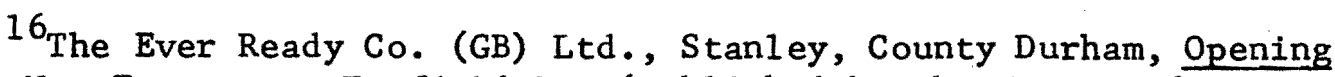
of the New Factory at Tanfield Lea (published by The Ever Ready Co. for plant dedication, July 10, 1968).

17 Ibid.

$18_{\text {Ray }}$ Thomas, p. 813 . 
${ }^{19}$ Pamphlet on loans entitled Council for Small Industries in

Rural Areas (London: CSIRA, Credit Services Division).

$20_{\text {Board of Trade, Central office of Information, Government }}$ Help for Your Industries, Room to Expand (London: HMSO, May, 1968).

${ }^{21}$ North East Devel opment Council, A Survey of the Experience of Some North East Firms in Applying for Government Grants and Loans (Confidential) (Newcastle: Mimeograph, NEDC, January, 1968).

${ }^{22}$ U. S. Economic Development Administration, Management Summary Report, Third Quarter, FY 1970 (Washington, D. C.: U. S. Department of Commerce, April, 1970).

${ }^{23}$ North East Development Council, p. 12 .

${ }^{24}$ T. W. Freeman, Geography and Planning (London: Hutchinson University Library, 1958), p. 119.

${ }^{25}$ Gavin McCrone, p. 97.

${ }^{26}$ Ibid., P. 136.

27 Board of Trade, Distribution of Industry Policy (Board of Trade, Distribution of Industry Division: Mimeograph, August, 1969).

28 "What the Conservatives Have Promised To Do," Manchester Guardian Weekly, - June 27, 1970, p. 9.

${ }^{29}$ John Osborne, Britain: The Land, The People, The Spirit (New York: Time Incorporated, 1967), p. 147.

$30_{\text {Ibid. , p. } 64 .}$

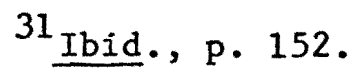

32H. E. Bracey, English Rural Life: Village Activities, Organisations and Institutions (London: Routledge \& Kegan Paul Ltd., 1959), p. 208.

${ }^{33}$ Board of Trade, Distribution of Industry Policy.

${ }^{34}$ Ibid.

35 Ibid.

${ }^{36}$ Ray Thomas, pp. 935-937.

37"A Guide for Industry," London Times, March 26, 1972. 
CHAPTER V

LOCAL GOVERNMENT PARTICIPATION

The State of the Art of Planning

American planners and students are accustomed to finding the British at a more sophisticated level than we are in the United States. It comes as a surprise when the most prestigious British study of local government claims that, as in America, there has not been sufficient recognition that economic planning and 1 and use planning are indivisible and that local government should be more concerned and more involved in economic planning.

Central government in Britain has assumed responsibility for economic planning, while local government has responsibility for 1 and use planning. The rigidity with which the two have been mutually exclusive is what is surprising. Recommending far-reaching reform, the Royal Commission on Local Government in England (Redcliffe-Maud Report) commented in its 1969 report:

In an area where the prospects are poor, one of the main concerns of local government ought to be what it can do to improve them, to increase the attractiveness of the area to employers, to help labour to move from declining to new employment, to provide new opportunities for employment. Local government has not, so far, been encouraged to do much in this way (except through the medium of town development schemes whose purpose, however, is housing), partly because it is not geared to do it but partly also because its responsibility for economic planning is not recognised. It must have this responsibility, within the limits of its general purposes and scope and in collaboration with central government. Otherwise it cannot do its job adequately... Nor can central government achieve its objective of a more even 
spread of prosperity between the different regions of the country without the help of local initiative and local action. 1

The situation probably prevails in most English jurisdictions, but it is less true in County Durham where dire need has stimulated more local government economic planning and promotion. In any event, local government activity is crucial to the purposes of the British economic development program.

\section{Local Government P1anning}

The Town and Country Planning Act of 1947 set up the comprehensive system of planning which has lasted for 20-odd years, under which the County Councils and County Borough Councils have been responsible for controlling all development. They have prepared plans to show how al1 1 and is to be used and submitted them for approval to the Ministry of Housing and Local Government. But the mass of detail, and the provision for public inquiry into objections, meant that years could pass in the preparation of the plan and then more years which the overburdened central administration would require to approve them. Plans had to be reviewed each five years as well. 2

In 1964 a Planning Advisory Group, officials from local and central government primarily, was asked to appraise the system. They reported these major defects: (1) too much detail for any practical and timely central government review, (2) inadequate development plans, as instruments of regional planning, and (3) as a consequence, a "lack of public confidence in the system." The Group proposed that the development plans deal only with broad physical structure and principal policies and priorities, and that details of implementation become the 
responsibility of local planning authorities. ${ }^{3}$

These proposals came at a point when many people had grasped that the country's demographic and economic growth were 11kely to be much faster than anyone foresaw when the 1947 Act was passed.

The South East Study, and other regional studies which followed, showed the frightening volume of development to be accomodated within a small island. Planners... (had) increasing responsibilities for promoting and directing the flow of development. Meanwhile...the job originally given to town planners was disintegrating. They had to play their part in economic planning on a regional and national scale, and deal with transport and communications, with the location of industry and the growth and distribution of incomes, and with the impact made by planning decisions on education, health, wild life, the pollution of the environment and many other matters. ${ }^{4}$

The reform in planning proposed by the Planning Advisory Group was enacted in the. Town and Country Planning Act of 1968. It provided for a new development plan system comprising structure plans and local plans. The structure plan would continue to be developed locally and submitted for central government approval, but the mass of detail in local plans would, within certain limitations, remain a local prerogative, and the approval machinery would not have the burden of passing on all the details. There were also a number of improvements in the general system of planning control designed to speed up the handling of. minor planning applications and of certain unopposed orders, and to make information about planning applications more readily available to the public. 5

The whole country is now covered by approved development plans, and with the new procedures they will be able to keep them up to date without the burdensome central government workload. Before the reform, some 470,000 planning applications were dealt with each year, of which 
about $83 \%$ were granted. About a quarter of the denied applications were appealed. 6

\section{Local Assistance to Industry}

For the writer a county planning official in County Durham outlined his conception of the economic development planning functions of his office. He said that industry is only one of the things that County Durham wants and needs, of course, and the planning program requires a comprehensive approach:

(1) The network of transportation has been archaic. Money has been pumped in, both central government money for main routes and local money for links and town center roads.

(2) There is a need to rationalize the settlement pattern of the county, in which $10 \%$ of the population lives in colliery villages with 1ittle or no reason for continued survival. They look terrible, contain much substandard housing, and spread the labor force too far from work, especially for the number of workers who do not own automobiles. This population must be regrouped, although resistance is firm.

(3) 7,000 acres of derelict 1 and left by coal mining and decaying villages needs reclamation. The dereliction is an eye-sore, affecting the quality of life. The central government provides $85 \%$ grants which could be used to transform dereliction into industrial sites but the colliery sites are not necessarily well chosen for new industry siting. They are expensive to clear, subject to continuing mining subsidence, sometimes combustible, and of ten non-competitive with good 1 and still available elsewhere. 
(4) The attraction of industry is needed to provide an adequate economic structure, but often the local authorities must speculate in 1and and buildings before they have any new industry in prospect. For example, the town of Spennymoor mounted a very expensive town center building and housing program, and industrial site preparation project, before new industry arrived to help pay the costs of the redevelopment effort. The Town Clerk told of many sleepless nights over the risks taken by the town leadership, and by him.

(5) The element of coercion by the Board of Trade (I.D.C.'s) is important to getting industrial prospects, but about half of the prospects come directly to the county planning office. Some come by referral from the North East Development Council, the regional promotional organization composed of representatives of local authorities. However, the county office gives information, promotes on its own (a modest advertising budget and some direct mail), squires prospects about, takes care of planning permission details, collaborates with second tier local authorities in providing 1 and and buildings, and concentrates on landing the prospects. An average success ratio of 1 to 10 a few years ago was reported now to be 1 new plant in 6 prospects.

(6) In addition to the Board of Trade financial assistance, County Durham offers cash aid to industry to help attract and steer growth. (a) The County makes direct grants, if the firm runs into high site costs (the County authorizes approximately 20,000 to 30,000 pounds per year for this purpose). (b) The County purchases mortgages on land and buildings, to fill the gap between the Board of Trade help 
and a maximum $75 \%$ of the cost of 1 and and buildings. The B.O.T.A.C. judgment of industry feasibility and reliability is accepted by the County. The interest rate is high and usually the larger companies do not want loans from county government. However, the County had a total of about 500,000 pounds out on loan at the time of the visit of this writer in October, 1969, to firms employing 1,700 people.

(c) The County can make direct acquisition of a site and resell at the lowest feasible price (usually at cost). In the 1950's, a complete Industrial Inventory was begun (sites, costs, services, etc.) but fragmented ownership of private land was a problem. Therefore, the Council started buying the sites, often sharing the cost with District Councils on a 50-50 basis, and sometimes putting in the access roads and other facilities needed. 7

\section{Infrastructure Assistance}

Programs have placed more stress in the United States on preparing lagging areas to attract industry than on direct aid to industry. In that one sense, infrastructure assistance has received more emphasis on this side of the Atlantic, even though as a proportion of gross national product the British have extended far more help to Development Areas than we have.

The American Area Redevelopment Administration in the early 60's was modeled on the British system, emphasizing industrial aid, but had less success with its business loans than it did with its other tools. The successor agencies, the Economic Development Administration and the regional commissions, were written to emphasize transportation and community facilities as the necessary condition precedent to the 
movement of industry to designated areas. The direct aids to the incoming industry are minimal; only about 50 direct loans each year are made by EDA in the nearly 1,000 qualified areas.

At the regional level, the British and American programs flowered at about the same time, the mid-60's. Since the formation of regional economic boards and councils in Britain, they have done a more effective job of rebuilding regional infrastructure important to economic development. The chapter on British regional policy will discuss the subject at greater length, but it is useful to note here that national priorities have been changed to favor Development Areas in the construction of highways, port modernization, and aid to local authorities for town center construction (urban renewal), housing, sewers, water, and other community facilities.

Only the Appalachian Commission program in the U. S. has developed a comparable regional approach, with extra financial assistance to highway construction, water resource development, and other key regional and local infrastructure construction. The other regional commissions in the American program have not been as generously funded.

\section{Community Assistance}

Community aid is difficult to compare in the two countries because there are certain practices in Britain which do not exist in this country. An important difference is that local authority revenues are leveled across the board. It has been proposed to do the same sort of thing in America by means of revenue sharing, but enactment is still awaited. The British Rate Support Grants do, by means of redistribution, favor the Development Areas which have less rateable property. 
Most local revenues come from rates (property taxes) which do not respond quickly enough to rising incomes, costs, or demands, and must be collected through a needle which is in plain sight and a bit blunt. These handicaps to adequate local government finance have resulted in substantial central government assistance, the bulk of which comes in a general or Rate Support grant. This grant replaced categorical grants for 11 different services (Local Government Act, 1958). The total amount to be distributed in the Rate Support Grant each year takes into account the actual amount spent locally on the 11 services plus the overall situation with respect to costs, demand for services, general economic conditions, and the government's polito-economic budget policy of that year. The share each local authority receives is determined by a formula based upon total population, school population, children under five years of age, oldsters past sixty-five, density of population, road mileage per capita, population decline rate, and a little extra for the metropolitan areas. In other words, the local problems are reflected in the formula and the least favored local economies tend to be the most favored recipients of assistance. 8 The second major method of central financial support is the Special Purpose Grant provided for a variety of functional purposes such as education, housing, police, and planning. Third, and of considerable importance to Development Areas, is the Rate-Efficiency Grant (Local Government Act, 1958), which is paid to the poorer authorities whose income from rates falls below the average per capita level. This is almost purely a leveling device affecting a surprising proportion of authorities (four-fifths), because of the concentration 
of wealth and economic growth in the London and Middle England counties.

\section{9}

In addition, the DA's receive other favored treatment. The Local Employment Acts of 1960-66 empower departments responsible for "basic services" to give financial assistance in Development Areas where it will contribute to the development of industry. This appears to be similar to the sewer-water-access road and other community facilities grants made by American programs, especially EDA, where they facilitate particular economic expansion.

Since the British areas are usually in mining and metal processing regions, substantial effort is going toward reclaiming derelfct land. This is usually 1 and despoiled by mining pit heaps at coal mines and slag heaps at iron or steel mills. Very little can be built safely in some of the undermined areas. Land being as precious as it is, the English recognize that these areas must be restored. The Ministry of Housing and Local Government provides grants for this purpose.

All told, the British assistance to local government is many times that of the United States in their economically distressed regions. Only in the programs labeled as development area aid do the Americans place greater proportional stress on infrastructure assistance. In programs not especially assigned to help unemployment areas the Americans rarely give any preference to such areas.

Housing

General policy direction of local low-cost housing, including the fixing of rents, is exercised by local authorities without central 
government control, but a number of statutes do require' local housing authorities to secure the planning approval from the Minister of Housing. These include general plans for dealing with housing, new housing proposals, condemnation for slum clearance or acquisition of land, and as important as any of these, the borrowing of money is subject to ministeriai consent. 10

The other prime element of central influence is that subsidies are paid to local authorities according to the amount of public housing made available. These are called Exchequer Subsidies. The subsidy income is an important factor in keeping rents down to a level which tenants believe they can afford to pay. Increasingly now the level which tenants believe they can afford to pay is based on tradition perhaps more than income, but this becomes a very real political factor. 11

Housing remains a controversial national issue as well as a troublesome local issue. Every town has a housing problem, and generally nationwide it is regarded as the most serious of the social problems. Some local authorities, however, give priority to the needs of older people while others concentrate on slum clearance. Some emphasize building houses for sale. A local authority may concentrate on receiving overspill from a larger adjoining urban area, or may concentrate on its own slum clearance. The variations are considerable and policy affects which particular group is to receive priority attention. $^{12}$

Perhaps the greatest weakness in the British economic development system is the relative inattention given to solving housing needs of 
new or expanding industry. Emphasis on local planning and local population requirements have made it difficult for the attraction of new industry to the DA's. New industry usually wants to bring key personnel, which is quite understandable, but often has great difficulty in getting them housing. Many local authorities make very little provision for outside people, even though in other ways they may be trying to attract them. Furthermore, the lack of better quality housing has made the lagging areas unattractive to the more sophisticated and affluent industrial executive and professional personnel, and has acted as a deterrent to development. Perhaps the regional boards and councils will help to encourage provision for housing incoming people in attractive quarters.

\section{Conclusion}

The usual description of British economic development programs neglects the role of local government. One is compelled to observe that such descriptions are not only incomplete but misleading. Local government plays a fundamental role in planning controls and infrastructure provision, and an important supplementary role in the provision and management of incentives, as well. 


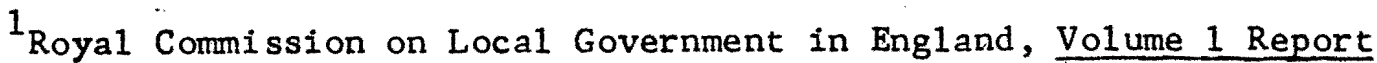
(London: HMSO, June, 1969), p.17.

2 Peter Levin and David Donnison, "People and Planning," Public Administration (London), Volume 43, No. 4, Winter, 1965.

3

Ibid., p. 474 .

4 Ibid.

${ }^{5}$ Ministry of Housing and Local Government, Joint Circular 66/68, "Town and Country Planning Act;-1968" (Whitehall, Lond on: HMSO, 1968), p. 1 .

${ }^{6}$ Central office of Information, Town and Country Planning in Britain, Reference Pamphlet No. 9, p. 5 .

7 Interview, J. A. (Tony) Cooper, Industrial officer, County Durham Planning Office, Durham City, October, 1969.

${ }^{8}$ J. A. G. Griffith, Central Departments and Local Authorities (London: Allen and Unwin, Ltd., 1966), pp. 63-65.

${ }^{9}$ Ibid., pp. 70-71.

$10_{\text {Ibid., p. } 220 .}$

${ }^{11}$ Ibid., p. 221.

12 Ibid., p. 248. 


\section{CHAPTER VI}

\section{NEW TOWNS}

As is well known, the story of the New Towns Movement began in Great Britain with the publication of Ebenezer Howard's book, Garden Cities of Tomorrow (1898) in which he hypothesized that crowded Londoners would be "healthier and happier if many of them moved beyond the fringe of the great metropolis into small 'garden cities.' He viewed London as a classic example of chaotic growth."1

His purpose was characteristic of an environmental program, and for a number of years this was the paramount consideration in proposals for new towns. In many quarters, it still is.

Great Britain has made new towns an element of governmental policy for many years, and has built more of them than any other country. Since the passage of the New Towns Act of 1946, some 24 communities have been government-sponsored in England, Wales and Scotland. (See Figure 6). The purpose has been to drain off excess growth from the largest cities (primarily London), provide new housing needed by low and moderate income people, and counter suburban sprawl, which the English call "overspill."

Availability of housing, and to some extent of jobs, was intended to entice the Londoner to leave the urban core.

More recently, however, new towns have become purposeful instruments to launch new economic and population units in Development Areas. Population continues to increase in Britain, faster in the favored 


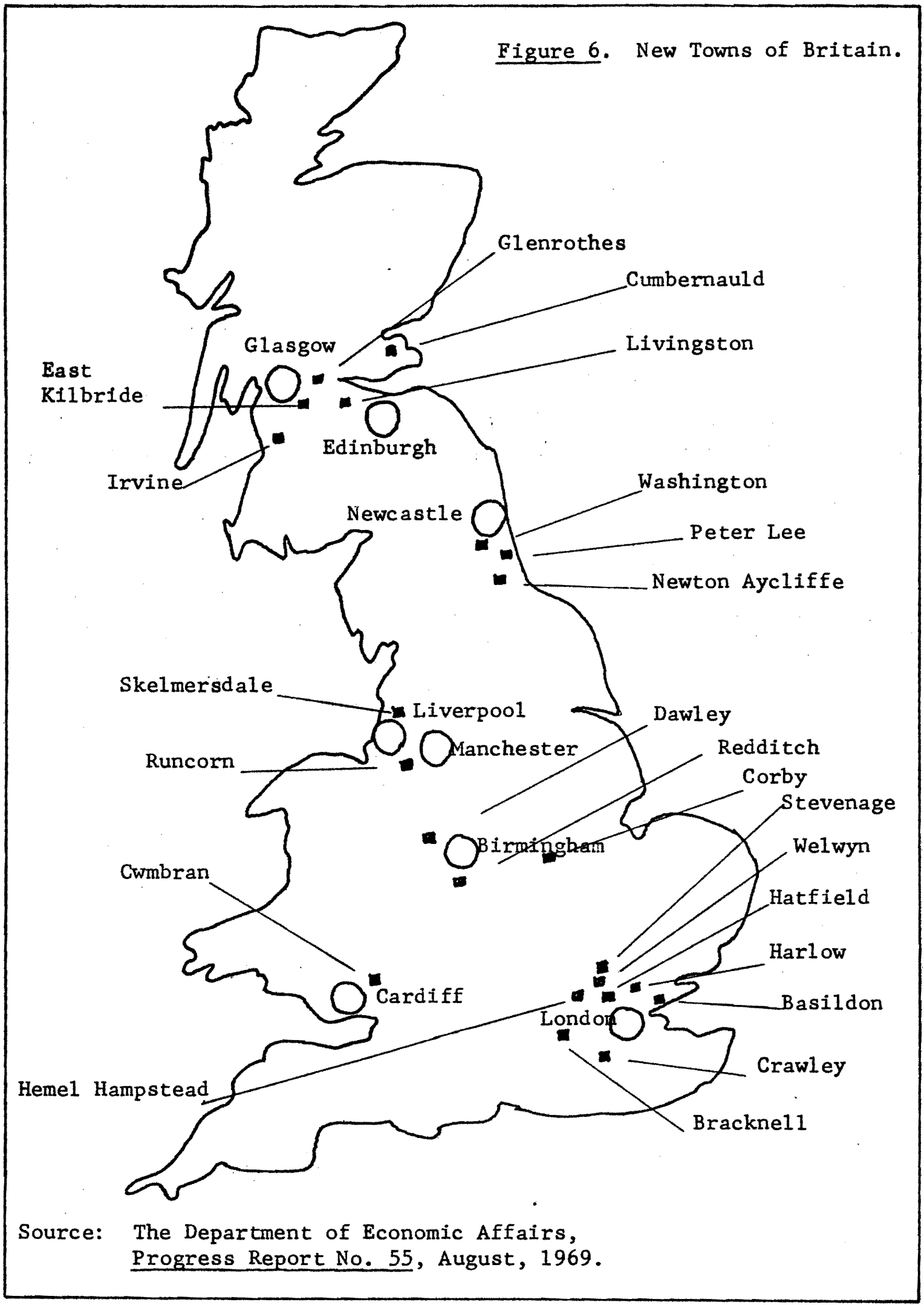


areas of South East and Midlands England, more slowly in the less fortunate older industrial cities and rural areas to the west and north. The trend toward the concentration of population, economic and political power, and educational, cultural, and public facilities, continues in the major metropolitan areas. The situation parallels that of the United States except that Great Britain is much more densely populated, has correspondingly less 1 and to waste on urban sprawl, and has fewer resources for exploitation.

The new towns came in three waves. (1) London's new towns were designated in the years 1946 to 1949 . The purpose of this wave was primarily environmental. (2) The second wave was provincially located new towns designated, with one exception, between 1947 and 1950 by the Labour Government, primarily for employment purposes. The exception was Cumbernauld designated in Scotland in 1955, but a part of this wave. (3) The most recent wave, called the new New Towns, has come as the product of regional policy. These new towns were designated from 1961 on.

The new towns of Britain have now become tools of economic development; more than that, economic development and new towns have become tools of regional economic planning. This is a comparatively recent dynamic.

During the Labour Government of the late 1940's, new town development and the effort to steer industry to $\mathrm{DA}^{\prime} \mathrm{s}$ were given vigorous attention. However, during the 1950's the Conservative Government did not press the distribution of industry policy. The new towns "struggled hard to attract new employers with only moderate 
success. ${ }^{3}$

The Conservative Government in the late $50^{\prime} \mathrm{s}$ and early $60^{\prime} \mathrm{s}$ restored the Development Areas programs. A further quickening of the pace came when the Labour Government returned to power in October, 1964, with the promise to "Get Britain Moving." 4 Labour honored its electoral pledge to create more new towns and to press for planned expansion of some existing towns. These policies were responses to the need for housing and rehousing of many people and for redistribution of industry and population growth. There is general recognition, unlike the situation in the U. S., that adequate scale can be achieved only by public initiative in acquiring 1 and, purnp-priming with capital, attracting jobs to the expansion locations, and providing adequate planning staffs.

The New Towns Acts of 1946 and 1966 empoxer the government to designate 1 and for a new town and to appoint and finance a development corporation in order to plan and build the new comunity. Development corporations have wide powers, including the power of eminent domain, within the designated area. The machinery of the Acts enables the government to take direct action in planning for the distribution of population. Increasingly, it is recognized that planning for the distribution of industry, facilitated by the attractiveness to employers of new towns, is the key to redistribution of population. 5 However, the overall stagnation of the economy, prolonged by the international imbalance of payments and the antiquity of much of the industrial plant, keeps relentless pressure on government program finaneing, handicapping solution of internal problems. 
The expected increase in the country's population poses great problems of investment and location. Apparently the median estimate now is that there may be 17 million more people in Great Britain by the year 2000 , and that the rate of increase will be $2 \frac{1}{2}$ times as great as it has been for the past 35 years. 6

The regional strategies are to keep provision of jobs, homes, and services in step with each other and with the national population growth, at the samie time giving attention to the conservation or improvement of human environment. New towns figure prominently in these strategies. Three of the specific regional planning objectives listed by official sources are as follows:

- to provide a general planning strategy for each region in relation to population movements, industrial location, economic and social infra-structure.

- to organise a planned movement of people and jobs out of the overcrowded conurbations to new or expanding towns selected in the light of regional planning strategy.

- to coordinate different public investment programmes as they apply in particular regions, so as to ensure that they are mutually consistent e.g., that the road building programme in any one particular region is related to the size of its housing and town development programmes. ${ }^{7}$

When the new towns movement was reborn in the early 1960's, it was seen as accomodating much larger populations than the earlier models, and substantially larger than the ideals espoused by Howard and other early visionaries. The new concepts of size and purpose resulted from adaptation of new towns to the needs of regions, rather than creation as environmental oases. (See Table VII).

Although the seven new towns in the second wave were not direct instruments of regional policy at their inception, they were related 
TABLE VII

ORIGINAL, 1969, AND ULTIMATE POPULATION

BRITAIN'S NEW TOWNS 8

\begin{tabular}{|c|c|c|c|c|}
\hline & Year of & Popul: & tion in thou & sands \\
\hline New Town & Designation & Original & March 1969 & Ultimate \\
\hline Lond on's New Towns: & & & & \\
\hline (Basildon, Bracknel 1, & & & & \\
\hline $\begin{array}{l}\text { Crawley, Harlow, Hatfield, } \\
\text { Homel, Hempstead, Stevenage } \\
\text { and Welwyn Garden City) }\end{array}$ & $1946-9$ & 99.5 & 451.8 & 642 \\
\hline The Seven New Towns: & & & & \\
\hline Newton Aycliffe & 1947 & 0.1 & 21.0 & 45 \\
\hline East Kilbride & 1947 & 2.5 & 62.6 & 100 \\
\hline Peterlee & 1948 & 0.2 & 21.9 & 30 \\
\hline Glenrothes & 1948 & 1.2 & 26.0 & 95 \\
\hline Cwmbran & 1949 & 12.0 & 44.1 & 55 \\
\hline Corby & 1950 & 15.7 & 48.1 & 80 \\
\hline Cumbernauld & 1955 & 3.5 & 27.0 & 70 \\
\hline Sub-total Seven New Towns: & $1947-55$ & 35.2 & 250.7 & 475 \\
\hline The New New Towns: & & & & \\
\hline Skelmersdale & 1961 & 10.0 & 18.6 & 80 \\
\hline Livingston & 1962 & 2.1 & 8.2 & 100 \\
\hline Redditch & 1964 & 29.0 & 36.5 & 90 \\
\hline Runcorn & 1964 & 28.5 & 31.5 & 90 \\
\hline Washington & 1964 & 20.0 & 24.3 & 80 \\
\hline Irvine & 1966 & 30.0 & 36.4 & 110 \\
\hline Milton Keynes & 1967 & 40.0 & 41.0 & 250 \\
\hline Peterborough & 1967 & 80.5 & 80.5 & 176 \\
\hline Newton & 1967 & 5.0 & 5.0 & 13 \\
\hline Northampton & 1968 & 131.0 & 131.0 & 300 \\
\hline Warrington & 1968 & 124.0 & 124.0 & 205 \\
\hline Te1 ford & 1968 & 70.0 & 70.7 & 220 \\
\hline Sub-total New New Towns: & $1961-8$ & 570.1 & 607.7 & 1714 \\
\hline Grand Total & $1946-68$ & 704.7 & 1310.1 & 2831 \\
\hline
\end{tabular}

NOTES: In some cases there was a large original population. Furthermore, this table does not include "expanded towns" in some of which the proportionate growth planned is larger than for some of the new towns. The figure given for ultimate population in some cases relates to the planned population for 1991 or the end of the century. 
primarily to employment problems, and they have been in.existence long enough to provide a reasonable basis for analysis of the role of new towns in regional policy. They have in themselves been successful. An analysis by Ray Thomas in Aycliffe to Cumbernauld (1969) describes the single most outstanding achievement as being their contribution to industrial growth, but also sees them as having stimulated regional plaming significantly.

Al1 three of the Scottish new towns--East Kilbride, Cumbernauld and Glenrothes--and Newton Aycliffe in County Durham have brought pockets of prosperity and almost full employment to within otherwise depressed regions. Without these new towns the problems of Scotland and north-east England would be that much more intractable.

Instead of being part of the result of comprehensive regional strategies the new towns have, ironically, provided an inspiration for new regional strategies. The success of places like East Kilbride has helped to produce the idea of the 'growth point strategy' which is now the mainspring of regional plans being formulated in many parts of the country. 9

Thomas's enthusiasm is tempered by his criticism that the new town idea and the growth point strategy do not directly help existing settlements, and that the new towns are not making an adequate contribution to housing the "truly underprivileged" who are left in the hands of the local authorities in the "historic towns who also have to face all the difficulties of an antiquated urban structure." 9

Six of the seven middle wave new towns were established near or within the present day Development Areas. Peterlee, Glenrothes, and Cwmbran were directly or indirectly intended to house coalminers; Glenrothes and Cumbernauld were intended to take overspill from Glasgow (one of the most substandard of Britain's cities in housing and population density); Corby was designed to house the workers of a single 
firm, a steel mill. The seven are, therefore, a varied lot, but some conclusions can be reached by examining the employment records.

Table VIII shows the employment in the years $1951,1961,1966$, and 1968-9, providing evidence of the extent of growth. All of these new towns, but Corby, benefited from the regional industrial location incentives, and all can provide advance factories by means of new town financing, as well.

Table IX, while the data is not precisely applicable to new towns, shows employment movement to the regions (Northern England and Scotland), which have the lion's share of these new towns. Thomas sees this relationship between the data:

First, that the new towns have contributed to a substantial proportion of all new industrial growth in the north, and especially in Scotland, in recent years. Secondly, that the number of moves to the north in the $1960^{\prime} \mathrm{s}$ is substantially above that even of the early postwar period when a strong industrial location policy was previously being pursued. The figures suggest that the new towns have made a substantial difference to the effectiveness of industrial location policy in the $1960^{\prime} \mathrm{s} .13$

For new towns in all free nations, however, there are problems of geographical mobility which cannot be ignored, especially among the British who have shown less willingness to break family ties and move than have Americans. Availability of housing is an enticement to Londoners living in cramped quarters, and new towns do ordinarily guarantee jobs, but executives and skilled workers are often reluctant to leave established urban centers. Workers may face a drop in wages, as well as higher house rents, and they fear their wives may not find jobs.

There are also problems of timing which plague all new town 
TABLE VIII

EMPLOYMENT IN THE SEVEN NEW TOWNS

$$
1961-1969^{11}
$$

\begin{tabular}{lrrrr}
\hline \multicolumn{1}{c}{ Town } & 1951 & $\begin{array}{r}1961 \\
\text { (thousands) }\end{array}$ & 1966 & $1968-9$ \\
\hline Corby (Midlands) & 10.5 & 18.4 & 23.5 & 23.5 \\
Cwmbran (Wales) & 8.5 & 11.7 & 15.6 & 15.8 \\
Newton Aycliffe (N. Eng.) & 3.7 & 6.3 & 12.0 & 12.6 \\
Peterlee (N. Eng.) & 0.5 & 2.5 & 4.3 & 6.3 \\
Cumbernauld (Scot1d) & -- & 3.0 & 6.2 & 7.9 \\
East Kilbride (Scot1d) & 3.0 & 12.1 & 19.1 & 23.0 \\
Glenrothes (Scot1d) & 1.7 & 1.7 & 5.5 & 7.3 \\
& & & & \\
Total & 27.9 & 55.6 & & \\
& & & & \\
\end{tabular}

TABLE IX

MOVEMENT OF MANUFACTURING INDUSTRY

TO NORTHERN ENGLAND AND TO SCOTLAND 1960-1965 ${ }^{12}$

$1945-51 \quad 1952-9 \quad 1960-5$

Number of moves:

to Northern England

to Scotland

Employment growth over 1945-65

attributable to these moves

in Northern England

in Scotland

$\begin{array}{rrr}107 & 34 & 79 \\ 77 & 50 & 132\end{array}$

$\begin{array}{ccc} & \text { (thousands) } \\ 62.7 & 13.2 & 13.7 \\ 44.3 & 18.4 & 31.9\end{array}$


ventures. Problems were well summarized in Manpower Policy in the

United Kingdom, prepared by British agencies for the Organisation for

Economic Co-operation and Development (Europe) in 1968:

- The build-up of Industry sometimes outpaces that of housing. Additional help to local authorities in such circumstances is available (under a new Housing Subsidies Act effective in April, 1968).

- When the provision of housing falls behind the creating of new jobs the cost and inconvenience of lodging in the New Town or commuting until a house becomes available deters some workers from making a move and some of those who do take a job in the New Town may be forced to leave it and return to work in their town of origin.

In general there is no doubt that one of the greatest obstacles to labour mobility... is the shortage of houses at the right price in the right place at the right time. ...generally speaking the possibilities are restricted by the desire of housing authorities to give first priority to the housing of people already living in the area. 14 
${ }^{1}$ Hoyt Gimilin, "New Towns," Editorial Research Reports on the Urban Environment, William B. Dickinson, Jr., Editor (Washington, D. C.: Congressional Quarterly, January, 1969), p. 172 .

2

IbLd., PP. 171-172.

3ay Thomas, Aycliffe to Cumbernauld: A Study of Seven New Towns in Their Regions (London: Political and Economic Planning, 1969), P. 813.

4. Brian McLoughlin, "The Changing State of British Practice," Journal of The American Institute of Planners, Vol. 32, November, 1966, p. 351 .

5 Organisation for Economic Co-operation and Development, Manpower and Social Affairs Committee, Manpower Policy in the United Kingdom (Paris: Mimeographed, April, 1968), p. 75.

6

Department of Economic Affairs, Progress With Regional Economic Planning (London: DEA Background Paper, Mimeographed, November, 1967), p. 1 .

7Organisation for Economic Co-operation and Development, p. 66. Ray Thomas, p. 804.

9

Ibid., pp. $941-42$.

10

Ibid., pp. 942-43.

11

Ibid., p. 812 .

12 Ibid., p. 814

13

Ibid., p. 815 .

14 Organisation for Economic Co-operation and Development, pp. 34-36. 
CHAPTER VII

BRITISH REGIONAL PLANN ING

\section{History of Regional Organization}

British regional policy owes its development to three precedents and conditions: (1) the traditional use of advisory bodies, (2) the limited use of regional machinery for certain governmental tasks in the past, and (3) a new interest in economic planning in the postwar period.

The tradition of the advisory group goes back a matter of centuries. The Board of Trade, for instance, itself originated in meetings between merchants and members of the Privy Council in 1621 . In the late 1950's and into the $1960^{\prime} \mathrm{s}$, an average of eight new advisory committees were created each year, and by 1969 there were at least 240 in effect. ${ }^{1}$ In terms of having advisory groups, therefore, the creation of regional economic councils in the 1960's had ample precedent.

Administration by special regional arrangements developed first in Scotland, Wales, and Northern Ireland. Greater London al so became a regional entity in more recent times. As long ago as 1902, H. G. Wells predicted the "development of urban regions," and in 1905 the Fabian Society issued a report suggesting a "system of Executive regional government." ${ }^{2}$ During the depression regional concerns were shown in the creation of the Commissioner for the Special Areas of 
England, and the Commissioner with a comparable assignment for Scotland, created by the Special Areas Act of 1934.

The trend to regionalism received a boost when Area Boards were created in 1940 in 11 civil defense regions, and these boards were composed of labor, industry, and government. Their planning concerns related to production, and the war effort, of course. These became regional boards for industry after the war, and this kind of central government activity continued until 1964 when the regional Economic Planning Councils and Boards were established. 3

A regional activity more closely related to economic planning was the establishment in each Standard Region (delineated by the Treasury Department) of Board of Trade Regional Controllers in 1945. The Controller chalred the Distribution of Industry Panels, which were interdepartmental coordinating committees concerned with the field of industrial development. ${ }^{4}$

There were also regional organizations established by the Ministry of Town and Country Planning after 1947. These utilized a regional Physical Planning Committee, of which the Town and Country Controllers were chairmen. These committees ceased to meet in the mid-1950's, and a short time later the Ministry of Housing and Local Government closed its regional offices in an economy move. 5

The theoretical framework for the regional planning councils can be traced to the creation of the Royal Commission on the Distribution of the Industrial Population, which reported in 1940 (Barlow Report). It contained an important chapter on regionalism and recommended a regional system of administration, for the following reasons: 
(i) Depressed localities within a region would be able to call upon the cooperation and sympathy of the regional capital and of the whole region.

(ii) The problem of planning would be greatly simplified; the Regional Council would become the principal planning authority for the region, certainly for major regional requirements, leaving probably to joint committees where existing, or to existing local authorities, the detalled administration of schemes. Planning would receive a great stimulus and on more comprehensive and better organized lines than is at present possible with the multiplicity of small planning authorities; and housing could be better related to industry. Larger financial resources would be made available and decentralisation in proper cases could be discouraged, e.g., to satellite towns. ${ }^{6}$

The recommendation was not adopted at the time, al though it may have influenced the decision to establish the Ministry of Town and Country Planning in 1942 and the shape of postwar planning organization. The operation of the Barlow-proposed regional industrial development boards was to be primarily advisory and not confined to civil servants. This was in contrast to the operation of the regional controllers of production created in 1941, who, along with regional boards, had executive functions, and were a part of the Civil Service.

The main features of the period up to 1945 were, therefore, the growth in the devolution to regions of the functions of central departments, the development of regional machinery to coordinate home defence and industrial production, and the steps taken to deal with the problems of depressed areas. In the fifteen years after the end of World War II, all three features remained as part of the organisation of Government, but with important changes in their form, the general effect of which was to place less emphasis on the role of regional organisation.

The third precedent upon which the regional economic councils were based was the development of economic planning as a legitimate governmental tool. There was interest in all political parties in managing the economy after World War II, although naturally there was 
disagreement as to how extensive this management should be and under what circumstances. The Labour Government did establish an Economic Planning Board in 1947 to assist in the formulation of long-term plans. Membership was drawn from the economic ministries of the Government--Treasury, Board of Trade, Labour, and Power--and from trade unions and industrialists. It sponsored various production and industry committees until the 1 ate $1950^{\prime} \mathrm{s}$. 9

National Economic Development Council

Modern national economic planning dates from about 1960 . The first planning was concerned with proposing desirable rates of economic growth and devising policies which would encourage both the public and private sectors to reach the targets. Central to this new planning effort was the creation of a National Economic Development Council (NEDC).

The story of the creation of "Neddy" (as" NEDC became known) is a commentary on the emergence of economic planning as a legitimate government aspiration and also the pluralistic decision-making process, which is not always so apparent in the highly centralized British government. A key study, entitled "The Birth of Neddy" by James B. Christoph, was published in 1965 in Cases in Comparative Politics. Christoph noted the difference between the "virtuous circle" of economic development in the growth countries of Germany and Japan after the war, and the "vicious circle" pattern of slow growth in countries such as Great Britain. He hypothesized that planning for an economic goal is much affected by institutional patterns in a country. 
For Britain, the limiting facts include the presence of a large and fairly well-educated population seeking to keep up a high standard of living on an island which, though fertile, is much too small and short of resources to be self-sufficient. Planning must also be done within the framework of institutions that have evolved over decades or centuries and that have shown great resistance to quick change-for example, slow-moving parliamentary democracy; a dedicated, decentralised, and largely conservative civil service; and a loose, uncoordinated, and class-conscious trade union movement. Relevant, too, are a number of pervasive attitudes, for example, that physical controls should be resorted to as a last resort, that the pound sterling cannot be left to find its own level on the world market, that "fair play" is as important as ruthless efficiency, that cooperation with the bosses (Them) is a betrayal of one's mates (Us), and that the humanely educated amateur makes better policy than the expert technician.10

While most.other countries were espousing growth as a national goal, the British were more reserved about the values of growth, competition, modernization, and profit-making. There was, however, a rediscovery of planning which resulted from three influences:

(1) the pressures of a declining economy, (2) the political tactics which were utilized, and '(3) the conversions made to the idea of economic planning. 11

The incident that triggered interest in national economic planning came from an unlikely source. The Federation of British Industries held a conference in November, 1960 , on the rather general topic "The Next Five Years." The working group on economic growth produced a report at this conference which constituted a "blunt and formidable attack on the country's recent record and the policies that underlay it...." It concluded that it was time for government and industry to get together to evaluate their economic situation and focus the country on the next five years of economic effort. This incident, followed by some letters to The Times, resulted in the calling of a 
conference at Easter, 1961, on economic planning in France, which was being advocated as a model for Britain's guidance. Advocacy was coming in part from the Organisation for European Economic Cooperation (renamed in 1961 the Organisation for Economic Cooperation and Development, OECD), from Political and Economic Planning (PEP--an Independent, non-party British organization doing public research since 1931), and from the National Institute for Economic and Social Research, which had published a comprehensive report on growth in the British economy in 1960 and $1961 .^{13}$

The view of French planning communicated to the British officials and businessmen at the National Institute's conference, then, stressed two things: first, that effective planning required the continuous mingling of government and industrial personnel and plans, and, second, that to bring this about there must be a central staff of growth experts, loosely attached to the government machine but sufficiently independent from civil service.routines and the politics of the day, empowered to develop plans that will find both government and industry.

The businessmen were... surprised to learn how agreeably French industrialists had taken to planning, though it turned out that many of them were enthusiastic primarily because it had led to a lessening of competition, with the government's blessing at that. 14

The Conservative Government in power at the time responded to this demand for "capitalistic planning" and proceeded on a tripartite approach to economic planning: government, industry and 1 abor. Industry and government, with reservation and specific procedural safeguards, were able to reach reasonably early agreement. Labor, however, was not nearly so anenable. There was the traditional hostility of the workers to the bosses. There was the close association of organized labor to the Opposition Labour Party and, therefore, the lack of effective lobby influence so long as the Conservatives 
were in office. And, at the time, organized labor was particularly Incensed at the Conservative view that the nation's economic difficulties were labor's fault--rising labor costs, restrictive practices and low productivity. There were also some internal structure problems in the Trades Union Congress which made negotiation difficult. However, the deed was done. Christoph found this noteworthy on several counts, including the following:

3. Interest groups played a role in all stages.... Taking part were not only economic groups such as the FBI and TUC (Federation of British Industry and the Trade Union Congress), but also growth lobbies such as the National Institute and, at a greater distance, the French planning mission areas and the OECD.

4. Decisions emerged slowly and only as the result of pressures. Britain's sluggish economic development was nothing new in 1960, but prior to that time old habits and the resistance of older institutions such as the Treasury and the trade union movement had proved so great that planning was at best fitful and uncoordinated. It took agonizingly long for the lessons to sink into the stable and conservative power structure, and only with the advent of new crises, intensified foreign competition, and Compon Market fever, did the appropriate politicians react. 15

\section{Regional Economic Development Councils and Boards}

The creation of the NEDC was important to the subsequent creation of regional councils and boards. The Neddy directed attention to the importance of regional development as a substantial contribution to national growth, by drawing labor resources into employment, as well as the traditional objective of reducing suffering caused by unemployment in certain regions. The Council recommended financial incentives for the regions and government expenditure on the social infrastructure, concentrating on "growth points" rather than broader areas of high unemployment. ${ }^{16}$ 
There were a number of crucial publications dating from 1962 onward that produced a marked change in the climate of opinion on reglonal questions. These reports recognized the growing complexity of the problems of physical planning, and, despite the location-ofindustry efforts, a continuing serious imbalance in the country's economy.

The regional concept was strengthened by these publications:

1. The Report of the Enquiry into the Scottish Economy (The Toothill Report), 1962.

2. The Report of the National Economic Development Council on "Conditions Favorable to Faster Growth," one chapter of which deals with regional questions, 1963.

3. The White Paper on the North East, 1963.

4. The White Papers on Central Scotland and Development and Growth in Scotland, 1963-64.

5. The Report of the South-East Study Group and the accompanying White Paper, 1964.

6. The National Plan, 1965, Chapter 8 of which deals with regional questions. 17

The distinctive feature of this series of pronouncements on regional questions is the much greater emphasis which is placed on the economic aspects of regional policy and on the need for coordinated plans of regional development covering the provision of housing and physical services as well as the stimulation or control of industrial growth. Physical planning is seen not simply as a means of providing for whatever needs may emerge but as an essential part of the process of economic development. From this follows the insistence on improved machinery for coordinating the work of Government departments both centrally and regionally, on the need for detailed regional studies and on the paramount importance of effective collaboration between central and local government. 18 
The Role of Technocracy

The changes in attitudes toward science, technology, and specialization have been particularly significant for economic planning. The Treasury,which always played the central role in measures affecting the British economy, was far from enthusiastic about impending change.

For years its top officials had followed orthodox economic policies and viewed with suspicion the idea of radical experimentation, especially if such experimentation involved outside experts, not trained in Treasury thinking or in the normal chain of command. 19

Treasury had taken on a few economists and trained planners during the war, but few of them reached top positions. Normally top civil servants were (still are) recruited from Oxford or Cambridge, and technically qualified personnel were (still are) treated as we treat consultants in the United States. More and more attention is paid to what they say, but they are not a part of the decision-making organization. The typical civil servant, especially in Treasury, "seldom had the opportunity to acquire first-hand knowledge of industry, trade,or a profession. He wa's examined primarily for general ability and not subject matter specialisation, rarely given much on-the-job training, and not encouraged to move back and forth between industry and government." During the period 1957 through 1962, 95\% of entries into the higher civil service were without a scientific background. 20 The creation of the National Economic Development Council and later the Department of Economic Affairs loosened the check reins of the highly educated, poorly-trained administrative class on economic planning. All is not proceeding smoothly; however, as witness the abolishment by Mr. Wilson in 1969 of the Department of Economic Affairs 
(returning powers to Tressury). However, Wilson's motive may have been a matter of governmental reorganization, rather than a resurgency of amateurism.

\section{Reg Ional Planning}

One problem in judging Britain's program is to arrive at some understanding of the meaning of the phrase "regional planning." Whatever it means, it is an extremely complex activity. It involves the making of and the relying upon projections of economic growth, of industry trends, of capital improvement requirements, and still more than those. It involves political behavior, and, to be successful, it must find ways of achieving effective political action.

Regional planning must guide action, but more. It must produce results; it must "cause" action! In Britain the action objectives of regional economic policy have been listed as these:

-- to achieve a more even balance between supply and demand for labour over the country, in order to avoid waste of manpower in the less prosperous areas, and tendencies to wage inflation in the "overheated" areas.

-- to encourage a broader based industrial structure in those regions which are too dependent on the country's older and declining industries and so discourage excessive migration to the South East and the Midiands.

-- to provide a general planning strategy for each region in relation to population movements, industrial location, economic and social infra-structure.

-- to organise a planned movement of people and jobs out of the over-crowded conurbations to new or expanding towns selected in the light of regional planning strategy.

-- to co-ordinate different public investment programmes as they apply in particular regions, so as to ensure that they are mutually consistent, e.g., that the road-building programme in any one particular region is related to the size of its housing and town development programme. 21 
The first concrete reaction in England to the series of regionally oriented reports in the early $1960^{\prime} \mathrm{s}$ was the appointment of a member of the government to be concerned with regional development. This was done in October, 1963, by the Conservative Government, which created the post of Secretary of State for Industry, Trade and Regional Development, held in conjunction with the office of President of the Board of Trade. It is interesting that the Prime Minister of the Conservative Government of 1970 was the first official to hold this new post. The experience has not seemed to augur well for regional programs under the Tories.

The creation of the regional ministry was actually preceded by the creation of the Scottish Development Department in 1962, and the publication of a report on Northern Ireland also dated in 1962. The most pressure for attention to regional problems did come from Scotland and from North East England. In the latter area, the voluntary body with the most influence on the decision was the North East Development Association, which is still active and was my host during my 1969 visit. A special investigation of the particular problems of this region was made in the autumn of 1963 when a senior Minister of the Government, the Lord President of the Council, reported on his on-thespot inquiry. As a consequence a policy statement was issued on development in North East England. This statement and the one on Scotland introduced a new concept in development policy, the "growtharea." This is a place picked for special assistance because of its potential for growth and its latent ability to generate further development. 22 
Regional planning became fashionable in Britain; as it had in

Europe. Max Beloff, writing for Encounter, "On Changing Intellectual

Pashions," April, 1969, comments on the phenomenon, as well as the

danger of nationalism which regional planning skirts.

And now quite suddenly, the landscape has changed! Since increasing centralisation has not produced its expected benefits, there has been a sudden reaction against the whole idea, a sudden rediscovery of the virtues of the smaller unit. Sometimes this is strengthened or pervaded by Nationalism-the Scots, the Welsh, the Bretons, the Basques, the Flemings show signs of taking up again the course of their national histories, Interrupted centuries ago by conquest and apparent assimilation--just as the Poles and the Czechs and the Slovaks, and other peoples of Eastern Europe did a half century ago. But nationalism is not essential to this feeling that too much is decided too far away. Cornish nationalism, perhaps; but Mercia, Northumbria?--that is really too much to ask. "Regionalism"--a neutral word--covers most of the debate where England is concerped; with Scotland and Wales the argument is more open.

This paper does not concern itself with the parts of the United Kingdom outside of England, but just a word may be in order. Northern Ireland has its own legislative and executive departments to deal with its domestic affairs, and therefore has its own economic development legislation. Scotland has no separate legislative branch, but since 1925 there has been a Principal Secretary of State for Scotland in the Cabinet, and since 1939 this official has had four departments in Edinburgh to administer. The departments since 1962 have been the Scottish Home and Heal th Department, the Department of Agriculture and Fisheries for Scotland, the Scottish Education Department, and the Scottish Development Department. For other purposes, the London ministries cover the whole of Great Britain. In 1949 Wales was given a Council for Wales and Monmouthshire. That counc1l was discontinued in 1966, and its economic planning function has been assumed by the 
Welsh Economic Council, which is the Welsh counterpart of the English regional planning councils. 24

The first study of an English region, the North East, published in November, 1963, did create something on the order of a regional structure by bringing all the offices of the central government departments to one building in Newcastle under the general direction of the Board of Trade. The Economist commented, however, that the report "does nothing to encourage (regional consciousness or purpose) either by local government reform or by urgently recommending the establishment of a truly regional unit of government that could"work as an institutionalised pressure group in the interests of the region"."

The Labour Opposition had its fun with the undramatic character of the proposal. Douglas Jay called it "a great new and revolutionary experiment in regional government--moving some officials from one building in Newcastle to another!" 26

When the Labour Government came into power in 1964, it established the Department of Economic Affairs and transferred responsibility for development of regional policies to the new department. It then announced that Regional Economic Planning Councils and Boards would be set up in the English regions and also in Scotland and Wales. Each of the councils was to be composed of members appointed by the Secretary (DEA) upon nomination from local authority associations, employer associations, and the trades union councils, and supplemented by additional appointments from the universities and other sources of experts. The function of the councils was to be the development of regional plans, and the rendering of advice to the central government 
on their adoption and implementation. However, the Councils had no executive powers.

Formed at the same time were the Regional Economic Planning Boards which were composed of the senior regional officers of the central government departments. The chairman of the Planning Board was the top regional officer of the Department of Economic Affairs, and he also was to be the primary liaison with the Council, regularly attending Council meetings and supervising the secretariat set up to serve the Council's staff needs. Other officials were to attend more informally and also participate in sub-committee work of the Council. The most important contribution of the Board was to assure cooperation and coordination among the departments and the provision of data and information to the part-time, volunteer Council.

In addition to their main task of ensuring that national and regional economic planning marches in step the Councils can do a great deal to encourage local authorities and unofficial organisations to adopt a regional approach to common problems. In many fields, such as the arts, tourism, and the rehabilitation of derelict land, the benefits are regional rather than local, and sufficient resources can be mobilized only by cooperative effort. With their wide membership, the Councils are particularly well fitted ${ }^{2}{ }_{27}$ take the initiative in stimulating action in these fields. 27

When it formed the Councils and Boards, however, the Labour Government essentially extended the North East regional set-up of the Conservatives to the other regions and gave them a planning structure and staff. Regional Councils and Boards were set up in six new planning regions in 1964. Arrangements for the South East were deferred because the South East study was under way and was to be reviewed before making a final determination. The South East Council was established about a year later. For econonic planning regions, see Figure 7. 


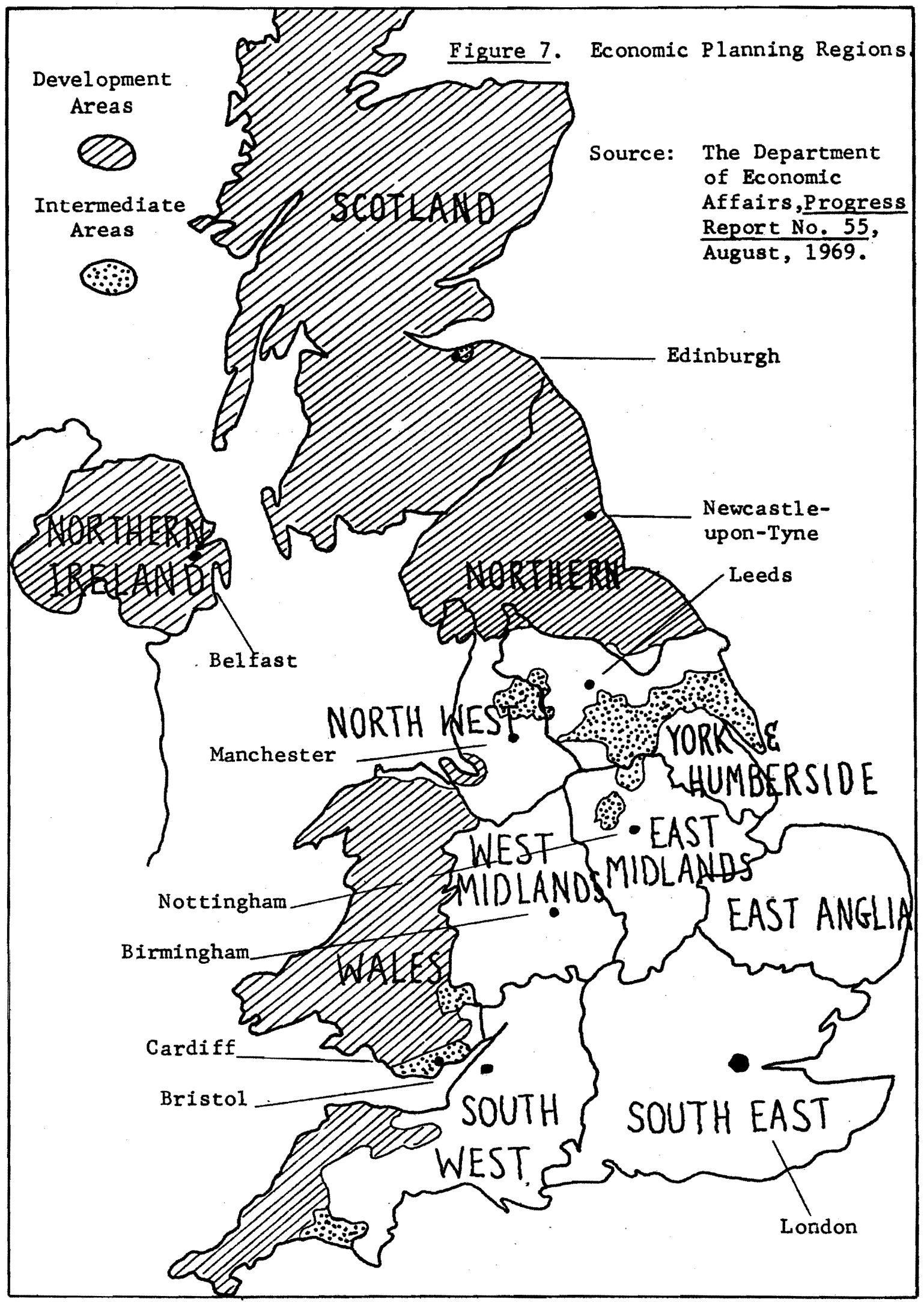


South West - A Case Study

The most complete history and analysis of the operation of one of the planning councils has been published by Bryan C. Smith, Advising Minfsters: A Case Study of the South West Planning Council, 1969. In that region there had been an early study made for a group set up in 1963 representing six counties. It covered all but two of the counties which ultimately became a part of the South West region. A number of local authority studies were also useful in preparing the regional plan. Additional studies were commissioned on particular topics such as the study of the economics of tourism which was conducted by Exeter University in the region. These projects were supported by central government funds administered through the Department of Economic Affairs.

There were in addition a number of organizations that made an input into the planning process. The Chairman of the Council met with outside bodies such as the South West Arts association, Plymouth Naval Dockyard Authority, the Water Resources Board, the Confederation of British Industries, and the Trades Union Congress South West Regional Advisory Committee. 28 As a result, a regional economic planning conference was organized in April, 1966 for the participation of such groups, conservation societies, and smaller local authorities.

The report, A Region With A Future, was actually written by the secretariat furnished to the regional council by the Department of Economic Affairs (DEA). The secretariat worked as a part of the office of the Chairman of the Regional Board, the regional representative of DEA. The drafts were then reviewed by the subcomittee structure of 
the Council and acted upon by the Council.

The document was called a "draft strategy" rather than a plan. Two reasons were advanced. One was that effective planning should involve executive powers but the Council had no such powers and did not want to create the impression that it was making actual operating decisions. Secondly, the Council wanted to avoid being held responsible for taking action on its proposals.

The Council was also guided in its approach to regional planning by the way in which the central Government envisaged its future work. In April 1967, the Department of Economic Affairs suggested that Councils should formulate a "strategic planning framework" for future regional development, covering such areas as population growth, industrial location and major communications within which individual projects may be decided upon and on the basis of which advice could be given to the Government on the regional implications of economic and physical planning policies, and, in particular, of -proposed regional public expenditure.

The Council decided that their strategy should be based on their reasonable aspirations, but made it clear that they had not costed or budgeted for their aspirations. This reflects in my view a singularly cooperative attitude toward central government problems and considerations.

Considerable emphasis in the regional strategy was placed on investment in regional infrastructure. The most important sector of that infrastructure was deemed to be communications, and a great deal of the Council's time was spent on evaluating the requirements for the region's ports, railways, roads, and airports. The Council also considered housing needs in the region, and its supplies of power and water. 30

The development of regional strategies and their publication 
served useful purposes in creating a regional feeling and goal among the population, but the primary function of the Council was advisory. It is often said by those defending the Councils that they could be made to look much, much better in the public eye if it were appropriate for them to advise the public when the central government has been responsive to their recommendations. The requirements of confidentiality in the relations between the Council and the central government makes it difficult to prove the worth of the Council activity. There is evidence, however, that the central government's departments are consulting with the regional councils. In January, 1966, the Minister of Transport announced her intention to consult with the councils on proposals for interurban trunk roads, which were in the planning stage for the decade 1970 to 1980 . The revision of the national plan after 1965 also involved the councils in advising the Department of Economic Affairs on estimates of 1abor, supply and demand, and activity rates. In the White Paper, A Plan for Polytechnics and Other Colleges, 1966, the Secretary of State for Education and Science indicated an intention to consider the advice of regional councils in establishing these training institutions. Other ministers followed suit to one degree or another. 31

The South West Council report was published in 1ate 1967, and the government responded in March, 1968. The council's strategy was generally accepted, and the government expressed an unwillingness to accept specific recomendations on only three strategic issues. First, the program for a road through the region would have to be more limited than the council recommended. Second, a proposal for a dock project 
in Bristol was not accepted. And third, Plymouth was denied the advantages of Development Area status, which had been recommended. The council later accepted the government's position on the road, but continued to express skepticism on the government's decision on the dock project. The council continued also to challenge strongly the argument about Plymouth as a Development Area, and this argument doubtless continued until the government relented after the Hunt Report on Intermediate Areas. 32

\section{Regionalism in Parliament}

The politics of regions are primarily party politics. This is not to say that decisions are totally partisan. Rather, the areas of greatest unemployment vote heavily Labour, as the comparable areas in the U. S. tend to vote Democratic. Consequently, the Labour Party's concern for regional economic growth incentives is bound to be greater than that of the Conservative Party. In the Northern Region, for example, in 1966, 30 Labour members were elected and nine Conservatives (no Liberals) for a total of 39 . In Yorkshire and Humberside (containing both DA's and Intermediate Areas), there were 39 Labour members, 15 Conservatives, and one Liberal, for a total of 55 . By contrast, in prosperous South East England, there were 101 Conservative members, 85 Labour, one Liberal, and one non-party (Mr. Speaker) for a total of 18 . $^{33}$

It might be claimed that Labour Government decisions favoring the distressed areas were made on a non-political, objective basis, only coincidentally helping heavily Labour constituencies. While there is considerable truth in the statement, it stretches credibility to a 
degree. For example, the Hunt Committee Report on the Intermediate Areas surely came at a time when it was least likely that the Labour Government would change its policies and withdraw some of its help to the most distressed Labour areas in favor of diversion to intermediate and politically mixed areas. Almost simultaneously with the Hunt Report, a political survey showed that the next election might return less than a third of the current Labour members. As The Economist noted,

The Government might be forgiven for not risking unpopularity in some of its traditional strongholds. Retaining Merseyside's privileged status in the north-west may not help much, but some trouble has been avoided by refusing more liberal industrial development certificates outside the development areas, which could only be at their expense. 34

Merseyside, of course, was the Prime Minister's base of operations.

There is also a political tendency affecting the quality of regional economic analysis. It is politically difficult to state regional prospects with complete objectivity, because forecasts are assumed to reflect government intentions, and because political decisions on public expenditures and other actions affect what can be admitted to be appropriate regional targets. As the regional machinery improves (as it must, or be changed), there will be new regional demands on Whitehall. Speaking for keeping the regional organizations as strictly advisory, with a clear-cut separation in responsibility between the Council and the Board, Labour NP Douglas Jay argued:

For one other danger, ever present, is more likely to be avoided this way: that regional authorities not merely try to take over the functions of the Government, but develop a regional nationalism and conduct campaigns publicly against. other regions of the central Government. 35

In a country with a history of regional dissension, up to and 
Including the present difficulties in Northern Ireland; the concern about regionalism becoming nationalism is quite understandable. There is, however, increasing need and pressure for strengthening the regional function. The Redcliffe-Maud Report recommended provincial (regiona1) bodies which would perform certain limited functions, especially planning, and would obviously become advocate bodies for their regions. The provincial bodies would not be chosen, however, by popular election. They would be chosen by the local authorities within the region and be, therefore, responsive to the tier of government closest to the people. Members of the provincial councils would not feel as compelled to demagogic speech-making under those circumstances, I assume. At least, the provincial authorities would not be on the horns of a dilemma by being responsible primarily to central authority instead of the region, as are the present boards and councils.

\section{Evaluation of Regional Boards and Councils}

The question arises--have the regions lived up to the expectations for them or the need for them? The question was nicely phrased early in the life of the councils and boards by an official of the Department of Economic Affairs, A. W. Peterson, in a speech to the Royal Institute of Public Administration (November 25, 1965).

Descriptions of bureaucratic machinery are like the instructions one gets with household appliances. The parts of the machine are listed more or less intelligibly, and the way in which they are intended to function is described in deceptively simple terms. It is only by experience that one learns how the machine behaves in practice and which parts of it are awkward to handle. 36

Peterson saw two things as being essential to success of the regional councils. First, he thought the councils would need to 
"establish a reputation as bodies whose conclusions are supported by the best possible assessment of the region's economic potential." Second, they would have to enjoy the confidence of both the central and local government so that the central government genuinely consult them about regional questions and the local authorities likewise turn to them on decisions with regional amplications. To accomplish these things, members would have to walk a tightrope, trying for general support from their neighbors and at the same time attempting to espouse projects and policies not inconsistent with realistic national policy. 37 The first thing that caught the critical eye of the author of this paper, an American civil servant, is the reliance upon an Economic Planning Board made up of regional civil service officials. The se officials must be responsive to their own ministers. The Board is, after al1, an inter-departmental committee at the regional level. Under these circumstances, regional effectiveness must depend upon the personal effectiveness of regional officers, and an extraordinary amount of dedication to regional principles on the part of civil servants in London and department ministers. This situation did not escape the notice of a number of critics, friendly and otherwise, in Britain.

J. Bryan McLoughlin noted the criticism that the "civil servants on the boards will grind their own departmental axes rather than implement unified policy." 38 P. J. O. Self (1966) also was afraid that the civil servants on the board would be concerned with their departmental duties and that their loyalties would be vertical rather than hori"zontal. "Because departments have different views, concrete questions 
will tend to gravitate to Whitehall, there to be settled by 'the usual machinery" (including the Cabinet and Cabinet Committee if the issue is very controversial)..$^{39}$

There is doubtless merit to the charges and fears that departmental loyalties might override regional duty. But on my visit in 1969 officials (granted that they were civil servants) in the Northern Region seemed to feel that the senior regional officials of the central departments were showing substantial interest in and loyalty to the region. Nor did this writer hear any specific local criticism on this count.

Most criticism concerned the minimum effectiveness of regional recommendations to the central government, without implying that the regional officers of the central departments were failing to push the case for their regions. In 1967, it should also be noted, the boards were relieved of responsibility for making speciflc recommendations and were placed in a supporting role rather than the lead role. It was to be the councils, alone, which would be responsible for making policy recommendations. This step relieved the central government of suffering any embarrassment which might come of regional officials speaking on central policy.

The questions about the effectiveness of the councils, however, remained. With no executive powers and no elective responsibility, there was real question whether they could influence major policy decisions as they affected regional planning. The regional councils, moreover, had no staff of their own and one of the criticisms of their performance has been lack of staff. 
As might be expected, the people deeply involved with the councils are reasonably well-pleased with the responsiveness of the central government to their recommendations and results to date seem satisfactory to them. A member of the North West Regional Council, for example, wrote an article for the Manchester Evening News of July 3, 1969, under the title, "Why We Are So Proud of Our Four Year Record." He said:

"Words, words, I'm so sick of words! Is that all you blighters can do?" Eliza Doolittle's challenge to Freddy in My Fair Lady has been echoed by many people about our Regional Planning Boards and Councils. And such critics are right-but more emphatically they are wrong.

...nelther Planning Board nor Council has any formal powers --but each has something more important than power: influence. The story of regional planning over the past four years is one of growing influence for the good, as I believe, of the regions, and for the national benefit, too.

What influence? The answer to this 1 ies in what regional planning is all about. It is really a process of study and discussion of the facts, problems, and possibilities of each region, and of co-operation with bodies which do exercise power.

In the real world it is often impossible to say exactly why things happen; there may be many reasons. I would--to go back to Eliza Doolittle--never think that the Regional Planning Council and Board are "the beginning and the end" of the improvement of the North West.

But I believe they have been a good influence on its life since 1965, and that they--in one form or another--will play an increasingly useful part in a better future. 40

The harshest criticism heard by the author of this paper came from a local authority official. It is not too surprising that some criticism might come from that quarter. Local officials in both the U. K. and U. S. have a certain disdain for boards, commissions, and committees that do not have to face the electorate. Only elected 
officials,in their view, can be completely responsible: It is true, as Gavin McCrone notes, that because the councils have no executive power they "may be less inhibited than if they had the power to implement" the recommendations they make, and this also "implies that there is no commitment to carry out their recommendations." 41

Moreover, the advisory councils had appeared to local authorities to be the first step toward provincial regional bodies, which may turn out to be the case, and common sense told them that any new-found authority would more likely come from local government than from central government jurisdiction.

There have been a miscellany of other criticism of the regional councils and boards. One has been that the council has had no funds to disburse. This writer's experience in the federal government is that an agency with funds to spend to support or supplement the work of other agencies can be more effective in coordinating their performance than an agency which must depend upon the rhetoric of cooperation and coordination.

P. J. 0. Self expressed concern over the basic premise of preparation of regional plans by a political unit:

Because of the failure to analyse trends dispassionately, regional planning suffers today from a certain intellectual confusion and dishonesty. It is politically difficult often to state regional prospects objectively.... This political problem will not diminish, it will increase with the creation of the new regional demands to the attention of Whitehall. The best solution would seem to be creation of an independent Institute of Regional Studies....42

Another area of criticism, common among both central and local authorities, might be attributed to the continuing reluctance of the physical planners to allow for the overall approach of the economic 
planner. The physical planner begins with the neighborhood and plans to each succeeding larger unit, but when he gets beyond a single community he feels that there is such a reduced common interest as to make planning both difficult and too far removed from the people. The economic planner must start with a sufficiently large area so that oufficient data is available, which it is not for local areas, and so that an input-output model, or comparable analysis, can achieve some economic balance. Therefore, physical planners tend to be concerned about the lack of identity for the English regions, a feeling which apparently does not disturb the economists very much.

The opinions of at least some observers are encouraging. Bryan Smith concluded from his case study of the South West Economic Planning Council that most of the criticisms of the council could be attributed to an exaggeration of expectations. As advisory groups to the central government, he felt they were performing their function adequately. 43 In whatever manner the total governmental structure may be reformed to meet criticisms, the regional councils and boards have been a distinct step forward, and one that has produced acceptance of the regional approach to the solution of problems. The more important criticisms of regional policy have been that the results have not been adequate to the need. Nevertheless, McCrone's view is optimistic:

...as time goes on, the structure of the problem regions is gradually becoming more favourable; the declining industries cannot decline for ever, and new industries are playing a larger part in the national economies. As this process continues the problem should get easier. But if regional policy has achieved some results, many of the measures are still new and much remains to be learnt about their effectiveness. $4 \frac{I t}{4}$ is to increase this effectiveness that is the 
Northern Region--A Sampler

The Department of Economic Affairs published during its existence, up to 1969 , a monthly report called Industrial and Regional DEA

Progress Report. As a sometime feature of that report, "Regional

Notes" on the English regions produced through fragments of news the

feeling of the activities of the Northern Economic Planning Council.

The following excerpts are a sampler from these notes:

October, 1967. The Planning Council have discussed the Government's views on the regional study, Challenge of the Changing North. The Council have decided to pursue with the Government a number of outstanding points arising from the study. The Council were pleased to note that the Government had released the grant of 150,000 pounds to Tees-side airport. ${ }^{45}$

July, 1968. The Council Chairman, Mr. T. Dan Smith, has been in correspondence with the Prime Minister about the problems of clearance of derelict land. The Government has accepted a number of recommendations put forward by the Counc1l to speed up the rate of clearance, and in a recent letter the Prime Minister has invited the Council to work out, in cooperation with the local authorities concerned, a 3-year programme of work. 46

January, 1969. A Government Training Centre opened at Maryport, Cumberland; by Mr. Roy Hattersley, Joint Parliamentary Under Secretary of State, Department of Employment and Productivity, in November, provides the first Government training facilities for the West side of the Northern Region. There are already four other GTCs in the region, two more are to be opened during 1969, and a further. one in 1970.47

April, 1969. For a number of years ahead, the region will inevitably be faced with a massive loss of jobs as rationalisation and technical change affect so many of its basic industries. But the continuing inflow of new firms means that steady progress is being made towards a diversification of the industrial structure. Since the Local Employment Act, 1960, was introduced, 200 new firms have been attracted to the Northern Region; it had taken five years to attract the first one hundred of these, but the second hundred were secured in just over three years with the last 50 moving in during 1968. of these new firms, 154 are now in production and are already employing 27,000 workers. It is estimated that over the next four years a further 24,000 jobs will be proyided in these and the other new firms yet to start production. 48 
July, 1969. A Council Working Group has been examining the organisation, facilities and potentialities of the ports in the region so that the Council can assess, as part of an overall transport strategy, what future pattern of port development might be needed. * * *

The report concludes that the Tees is the premier port of the region. ***

Ma jor development is not recommended at any other port in the region. A number of ports will be faced with a difficult task of retrenchment and the report offers little hope for their future. Some do have alternative traffic but they will have to rationalise their facilities if they are to remain viable. A few of the smaller ports serving mainly local interests have a reasonably assured future within their existing level of trade. ${ }^{49}$ 
1

Brian C. Smith, Advising Ministers: A Case-Study of The South West Economic Planning Council (London: Routledge \& Kegan Paul, 1969), p. 2 .

2A. W. Peterson, "Regional Economic Planning Councils and Boards," Lecture to Royal Institute of Public Administration

(Department of Economic Affairs, Mimeograph, November 15, 1965), p. 1.

3

Brian C. Smith, pp. 31-32.

${ }^{4}$ Ibid., p. 31 .

${ }^{5}$ Ibid., pp. 32-33.

6. W. Peterson, pp. 2-3.

7

Ibid., p. 4 .

8

Ibid., p. 5 .

9 Brian C. Smith, p. 13 .

10 James B. Christoph, "The Birth of Neddy," Cases in Comparative Politics, James B. Christoph, Editor (Boston: Little, Brown \& Co., 1965), P. 46.

11 Ibid., p. 56.

12 Ibid., p. 58.

13 Ibid., PP. 62-63.

14 Ibid., p. 65.

${ }^{15}$ Ibid., pp. 86-87.

${ }^{16}$ Brian C. Smith, p. 29.

17 A. W. Peterson, pp. 6-7.

18 Ibid., p. 7.

${ }^{19}$ James B. Christoph, pp. 54-55.

20 Ibid.

${ }^{21}$ Manpower and Social Affairs Committee, Manpower Policy in the United Kingdom, Report by The United Kingdom Authorities (Paris: Organisation for Economic Co-operation and Development, Mimeograph, April 26, 1968), p. 66. 
${ }^{22}$ Central office of Information, Reference Pamphlet 80,

Regional Development in Britain (London: HMSO, 1968), PP. 10-11.

${ }^{23}$ Max Beloff, "On Changing Intellectual Fashions," Encounter

(London), Vol. 32, No. 4, April, 1969, p. 52 .

${ }^{24}$ Central office of Information, Regional Development in Britain, p. 8 .

25. Victor Wiseman, "Regional Government in the United Kingdom," Parliamentary Affairs (London), Vol. XIX, No. 1, Winter, 1965-66, P. 56.

26

Ibid., p. 69.

27 A. W. Peterson, p. 12 .

28 Brian C. Smith, p. 71 .

${ }^{29}$ Ibid., p. 80.

$30_{\text {Ibid., p. } 91 .}$

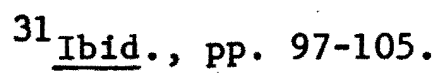

32 Ibid., pp. 121-123.

${ }^{33}$ G. H. Jones, B. C. Smith and H. V. Wiseman, "Regionalism and Parliament," Political Quarterly (London), Vol. 38, No. 4, OctoberDecember, 1967, PP. 409-410. p. 25 .

34"Shored Up," The Economist (London), Vol. 231, May 3, 1969,

35 Douglas Jay, M. P., "Government Control of the Economy:

Defects in the Machinery,". Political Quarterly (London), Vol. 39, April, 1968, P. 143 .

${ }^{36}$ A. W. Peterson, p. 15.

37 Ibid., PP. 15-16.

$38 \mathrm{~J}$. Brian McLoughlin, "The Changing State of British Practice," Journal of the American Institute of Planners, Vo1. 32, November, 1966, p. 351 .

${ }^{39}$ P. J. 0. Self, "Regional Planning in Britain: Analysis and Evaluation," Regional Studies (Oxford), Vol. 1, No. 1, May, 1967, p. 9.

${ }^{40}$ Department of Economic Affairs, Industrial and Regional DEA Progress Report, No. 56, September, 1969 (London: HMSO), pp. 7-8. 
${ }^{41}$ Gavin McCrone, Regional Policy in Britain (London: George Allen and Unwin, Ltd., 1969), p. 143.

42

P. J. 0. Self, p. 8.

43 Brian C. Smith, pp. 118-19.

${ }^{44}$ Gavin McCrone, pp. 165-66.

${ }^{45}$ Department of Economic Affairs, Industrial and Regional DEA

Progress Report, No. 33, October, 1967 (London: HMSO), p. 6.

46 Ibid., No. 42, July, 1968, p. 7.

47 Ibid., No. 48, January, 1969 , p. 7.

-. $\quad 48$ Ibid., No. 51, April, 1969, p. 7.

${ }^{49}$ Ibid., No. 54, July, 1969 , pp. 6-7. 
CHAPTER VIII

POLITICAL IMPLICATIONS

\section{Economic Planning}

The big story of the 20th Century British political scene has been the growth of the Labour Party. In 1945 the newly elected Labour Government came to power with the intention of bringing about a revolution in British economic and social policy through nationalization, socialized medicine, and government planning. The wartime Coalition Government had produced a number of proposals for programs which were to follow the conclusion of the war, intended to improve the health, housing, and education of the people. The Labour Cabinet, in addition to implementing these, pushed its nationalization program. Beginning with the coal mines in 1946, a number of state-owned monopolies were created, but virtually all of the nationalization proposals had passed by 1949 .

These changes were surprisingly well received. Although business obviously distrusted the Labour Party, "businessmen welcomed the decision to reorganize the economy," and "trade unionists and the intellectuals hoped that the new society would help to overcome the class divisions." 1 But by the early 1960's there was disappointment that not enough had been achieved and there was disagreement over what had gone wrong. Some thought there had been too much movement to the Left, some not enough. Actually, the economic predicament in which the 
British found themselves was simply beyond their capacity to resolve In a few short years. The Labour Government did produce nearly full employment and greater social equality, but economic problems did not yield to simple nationwide measures (hence the more recent regional approach), and Britain remained riddled with the effects of its continuing class conscious society. ${ }^{2}$

As noted earlier, the measures to cope with the problems of declining areas were less vigorously applied in the 1950's under the Conservative Government. As the British attempted to solve their recurring balance of payments crises, investment in the public sector was the usual victim. Through this postwar period of economic stress and strain, the Labour Party came into its own as one of the two major parties in the 1 and, and one generally considered to be competitive in political power. With the advent of socialist planning came economic planning, socialist, and otherwise.

\section{The Politics of Regional Planning}

With respect to regional economic development, it can be deduced that the working class has the most obvious stake in government programs, but the issue is not solely a class issue apparently. All classes and most interest groups have regional concerns (either as have or have-not areas) that can overlay class political affiliations. It may also be that the influence of the professions related to development (engineering, planning, architecture, economics) is being used to press for stronger regional development policy. In any event, this author detected no reluctance in any sector of the population of North East England to participate in regional programs. 
Regional bias in favor of economic planning and development is relatively new as a political phenomenon. While changes of attitude are evident, the pervasive British tendency has been counter to planning for growth.

While growth, competition, expansion, modernization, and profit-making are values which the majority of Americans would approve almost unreservedly, this has not been so in Britain for many years. These values, though they have had their advocates, are less ingrained in the culture and less likely to be transmitted from one generation to the next than other values, such as fair play or social justice. The very pervasiveness of the ethic of compromise, with its preference for continuity, gradualism, and bargaining among interests, makes Britons extraordinarily reluctant to accept the kinds of changes comprehensive planning may require. ${ }^{3}$

The feeling against planning in the Conservative Party was strong, of course, although Christoph notes that attitudes in the 1950 's were ambivalent because it had never been a party of "complete laissez-faire. $" 4$

Sharpe observed that there was good evidence that "social class is the most important individual characteristic determining political allegiance in Britain, but we have little notion of the variation and its dominance in different parts of the country." ${ }^{5}$ More recently, however, David Butler and Donald Stokes have explored the subject. They do not believe that the simplest facts of class composition can explain the difference in allegiance of class to party in the different regions of England.

In the first place, there are regional differences in class composition of the population. The ratio of working class to middle class is roughly 3 to 1 in the North and only 2 to 1 in London and the South East, whether measured by occupational class or class self-image, 
but the difference in class composition is less than the difference of party allegiance.

6

Closely examining election results in 1964 and 1966, the authors

noted a difference in working class vote results as between the

northern part of the country and the southern (which they call "the two nations").

Among those supporting the two main parties, the working class proportion voting Labour was 7.5 percentage points higher in the North and Wales than it was in the Midlands and South. But this difference would not by itself account for the partisan difference separating these two halves of the country even if every manual worker were Labour and every non-manual worker Conservative, which is by no means the case. The political cleavage between the two nations is also due to their differing patterns of party allegiance within the classes.... In the North of England, Scotland and Wales Labour's strength among working class electors in this period was as high as the Conservatives' strength among middle class electors; the level of 'cross-support' in the two class groupings was virtually identical. But in the Midlands and South, Labour's share of the working class vote was decidedly less than the Conservatives' share of the middle class vote; the balance of cross-support was 11.7 per cent in the Conservatives' favour....more than two thirds of the overall difference of 9.3 percentage points in Labour's strength in the two areas was due to the simple difference of the relative size of the classes.

Butler and Stokes claim empirical support for their belief that once the partisan tendency becomes dominant in an area "processes of opinion formation will draw additional support to the party that is dominant." 8

Economic class interest is doubtless a factor, but there are regional differences which do not have their roots, directly or indirectly, in class or in personal economic self-interest. "Part of the remaining variation is a legacy of the religious alignment; there is also a tendency for Conservative strength to be less in regions 
where the concentration of non-conformists is greater."

However, Butler and Stokes believe that an additional factor is part of the explanation of variations in party allegiance--the general economic situation in the various regions. If a regional economic interest can overlay the individual economic interest to a significant degree, even in class-conscious Britain, new and renewed sectionalism or nationalism could be the result. At this point, except for Northern Ireland, there appears to be a relatively constructive trend toward political support across party and class lines for regional growth policles wherever there is regional economic distress. 
${ }^{1}$ Douglas V. Verney, British Government and Politics (London: Harper and Row, 1966), p. 69.

2

Ibid.

3 James B. Christoph, "The Birth of Neddy," Cases in Comparative

Politics, James B. Christoph, Editor (Boston: Little, Brown \& Co., 1965), p. 54.

4

Ibid.

${ }^{5}$ L. J. Sharpe, Editor, Voting in Cities, The 1964 Borough

Elections (London: MacMillan \& Co., 1967), p. 9.

6 David Butler and Donald Stokes, Political Change in Britain

(New York: St. Martin's Press, 1969), p. 137.

7

Ibid., pp. 142-43.

8 Ibid., p. 143.

${ }^{9}$ Ibid., p. 150. 
CHAPTER IX

\section{CITIZEN PARTICIPATION}

\section{General Citizen Involvement in Government}

Citizen participation in both the U. S. and the U. K. is more apparent than real, but there is more reality for American citizen involvement in his government than for the British. With the very large city councils, and the extensive committee system of local government, the British involve a generous number of people, views, and special interests directly in their structure. In the American system, this diversity must often be introduced from outside the structure, through what we have taken to calling "citizen participation." Except indirectly through labor organizations, the low income group in Britain is not as well represented as in our country, particularly since the advent of American programs for the poor and the federal economic development program. Indeed, the sponsorship of citizen panels to promote and guide economic development has been a key element in the federal program of the Economic Development Administration. This chapter compares the British and American programs in this regard.

Economic Development Process in the U. S. and U. K.

The economic development process, while similar, starts at different points and takes divergent paths in the two nations. The American launching pad is the local level. There the entrepreneur, 
or the official with a public project in mind, seeks information, assistance, or support. The entrepreneur, if from outside the community, often starts at the Chamber of Commerce, and through it reaches a local development corporation if one exists, or reaches the Overall Economic Development Committee if the area participates in the federal EDA program. Sometimes the businessman will start at the county assessor's office or the planning comnission office to determine what local requirements and costs will be. Contact at the state level may be made when information on a number of communities is desired in a short time, or if the company looking for a site would like a buffer between itself and prospective location advocates. The state usually operates an economic development office, often in the Governor's office. If we take, in this latter instance, the promotional function of the state government to be an extension or representation of the community level, it can be said that the process of economic development in the United States originates almost entirely at the local level. Since few industrial sites are controlled by public agencies, the whole industrial location transaction may even take place without any contact with government.

In Britain, the starting gate is likely to be at the central government level. The businessman approaches the Department of Trade and Industry (formerly Board of Trade) for information and guidance with respect to plant location, with the sure knowledge that he cannot build unless the government grants him permission. Even a community project with economic growth significance must be discussed in early planning stages with the Ministry of Housing and Local Government, and 
often with other departments and with certain nationalized industries. The entrepreneur may also make an early approach to the county or County Borough Planning office, and through that channel perhaps to the lesser local authority which controls good building sites. Normally there would be little or no chance of utilizing 1 and not already desigmated for industry, but the planning office must in any case put its stamp of approval on any location decision. A site for any significant new economic activity, therefore, usually becomes a four-way negotiation among (1) the company, (2) the central government, (3) the county or County Borough Planning Office, and (4) the owner of the site (which could be one of the latter three). Very occasionally, and least often in the hard-pressed development areas, an amenity society may figure in the transaction in gadfly garb.

Figure 8 illustrates the contrasting U.S. and U. K. systems.

The Citizen Role--U. S.

The role of the private citizen, aside from the entrepreneur, is significantly different in the two countries. In the matter of acquisition of an industrial site and in economic planning, there is a role for citizen representation to play in the American program. Preparation of plans for economic development is officially a citizen function In the some 1,000 counties qualified for assistance from the Economic Development Administration (nearly one-third of the total number in the country, but composed of the less populated areas for the most part). The EDA asks that a representative citizen group be recognized or appointed by the county government. The function of the group is to plan and promote economic growth and coordinate and recruit all 
Flgure 8. Comparison of economic development systems, The U. S. \& U. K.
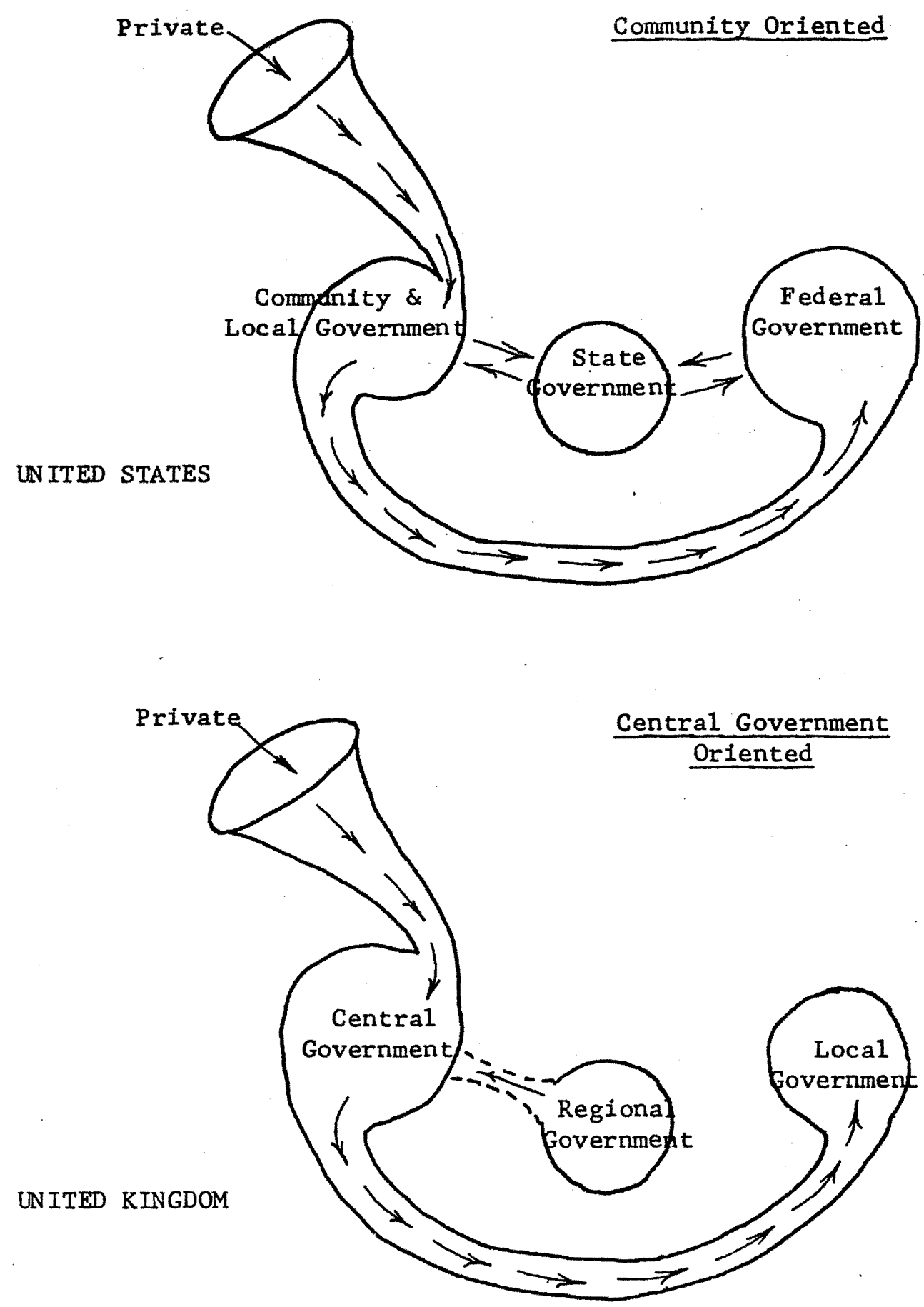
avallable resources to that end. The Overall Economic Development Committee includes but is not intended to be dominated by representatives of government bodies. Multi-county organizations (called "district" boards) have a similar mission, but their normal composition is $51 \%$ or greater representation by elected officials of local government. In some regions, plans are promulgated at the multi-state level, prepared by commissions appointed by the Governors and the federal government. States, on the other hand, have themselves been very slow to do comprehensive economic planning, though citizen groups normally are named by the Governor to promote development.

In addition to planning, there is active citizen participation in the American local development corporations which either acquire or prepare industrial sites or offer financial inducements to new or expanding industry. The local development corporation is intended or required to have a broad community purpose. Funds are sought by public stock sale, or loans, or both, and various cooperative endeavors are worked out with local government with respect to land acquisition, development, and zoning. The Small Business Administration is a common source of borrowed funds for these community groups, and the Economic Development Administration requires local development corporation participation (5\%) in any loans it makes to industry. Promotion and solicitation of industry, too, is essentially in the private sector in the United States, some help coming from state and local government. Local development corporations, Chambers of Commerce, utilities, and others participate while government plays only a sympathetic or supporting role. The provision of the site 
itself is still essentially a private land transaction, though there is increasing public and quasi-public industrial land acquisition.

In America, a relatively large body of citizens serve on the Overall Economic Development Committees, Chamber of Commerce Industrial Committees, local development corporation boards, and other groups promoting economic development. Furthermore, non-elected citizens play a significant role in U. S. planning, through service on local planning comissions which in Britain are functions of a committee of the council. A case can be made that some of the U. S. citizen participation is more form than substance. Often the citizen group plays a subordinate role to a professional, or a local government, or a federal program such as SBA or EDA. Sometimes the participation is actually only token, if that. However, whether or not it always succeeds, the American system is "intended" to stimulate the involvement of citizens.

The Citizen Role--U. K.

Figure 9 exposes the essential differences between the American and British programs. There are functiona1 differences, such as the matter of permission to build; great differences occur in the amount of resources committed $(\mathrm{Table} X I I I)^{*}$; and the scope of assistance available is signally different, as in the loans and grants of financial assistance to the entrepreneur.

Moreover, there are significant differences in citizen participation and in the sharing of activity between the public and private sectors. In Figure 9, all functions attended in whole or in part by * Table XIII, see Conclusion, page 188 
the private sector are denoted with the symbol (+). The only significant participation by the private sector in Britain is in providing sites for industry, and it ranks in importance below the public sector in that as wel1. Although not depicted, the capital lending function, which completely dominates the financing of new industry in the U.S., is important but proportionately less so in Britain as the government plays its significant part.

In only two steps in the process of economic development are British citizens at all involved. First, the regional councils appointed by the central government include representatives of various interests and institutions in the region. Labor, business, and university representation are provided, usually on the recommendation of organizations consulted by central government officials, but local authorities are the most strongly represented. Second, the development associations sponsored by various local authorities working in behalf of a region or subregion also include representation from interest groups. Chambers of Trade or Commerce are seldom active in seeking industry. They may feel no need to be.

The balance of this chapter tries to penetrate more deeply into the British system, the public attitudes underlying that system, and the current trends that relate to citizen involvement in public affairs such as economic development. The conclusion forced upon the author is that the strong bureaucratic and elective control of most facets of public life must inevitably loosen in the face of the pressures for more public participation, and indeed the loosening process is under way. The trend is significant in economic planning and the economic development process. 
A. Preparation of plans for Economic Growth

$* * 1$. County or Area Economic Development
Committee (non-professional,
volunteer; unstaffed usually.

*2. Multi-county District OEDP Board (majority local elected officials; with staff).

*3. Multi-state Regional Commission (only in some regions; composed of Governors and other state and federal officials and citizen leaders; with staff).

4. Federal government (no central planning function except in limited areas --forest resources, federal reserve banks, etc.).
1. County or County Borough P1anning officer (professional, responsible to elected council, input from lesser local authorities).

2. Regional Councils and Boards (nationwide; appointed by central government, composed of local government officials, citizen leaders, educators; staff from central government).

3. Central government (national economic planning, regional planning, and nationalized utilities and industries).

KEY: * Some citizen participation

*** Much citizen participation

+ Private sector

Figure 9. Function comparison of economic development programs--United States and United Kingdom. 
B. Promotion and Solicita-

tion of Employment

Producing Projects

$+{ }^{\star *}$ 1. Chamber of Commerce.

(In order of significant activity)

1. Central government.

2. Special Industrial or Port Districts (local tax authorities.

2. Local and regional development associations (usually sponsored by local authorities).

$+{ }^{* *} 3$. Local development corporations.

3. Local authorities.

4. State economic development office.

** 5. Overal1 Economic Development Committees, and district and regional organizations, encouraged by EDA.

6. Some local government bodies. 


\section{Function}

United States

\section{United Kingdom}

C. Provision of Sites for Industry

(In order of significant activity)

+1. Private 1and (most scattered, a few industrial parks).

+2. Private 1 and, utilities and banks.

$+{ }^{* *} 3$. Local development corporations.

4. Special Industrial Districts, cities and counties (a few).

D. Utilities and Services

+1. Private utility - gas, electric, and telephone.

2. Public utility districts and federal projects such as Bonneville and TVA, and some Rural Electric and Telephone co-ops.

3. Industrial park operator--can be public or private with small independent sewer, water systems.
1. Central government industrial estates.

2. Local authority industrial estates.

+3. Some private industrial estates, some scattered sites previously occupied by industries.

1. Nationalized gas and electric boards, national telephone service (Post Office Corporation).

2. Local authorities. 
E. Financial Assistance to Entrepreneur

(In order of significant activity)

1. Smal1 Business Administration, Economic Development Administration, regional commissions (federally supported).

2. State Industrial Development Funds (some states).

+3. Local development corporations (local stock sale and borrowed funds, usually in combination with SBA, EDA, or state).

4. Industrial revenue bonds (local taxing authority, usually a port or special district).

F. Permission to Build

1. Local planning commission (only if zone change is requi red).

2. State and federal pollution control agencies (control of operations, only indirectly affecting location).

1. Central government.

2. Loca1 authorities.
1. Central government (IDC).

2. Local authorities--County Planning Office and District Council clerk (must give specific site permission, and the site must fit comprehensive structure plan).

Figure 9. (cont.) 
Community Power Studies

The question of who actually governs, and even more the methodology of determining who governs, has occupied a great deal of attention on the part of U. S. political scientists and sociologists in the past two decades. The methodology has been grouped into three categories: the positional approach, the reputational approach, and the issues decision-making approach.

The positional method of determining influence and locating power has been based on the traditional assumption that people who occupy official positions in major institutions are the decision-makers. This lately has fallen into disrepute in the United States, but is probably the most reliable approach to locating the power centers in Britain. Nonetheless, the American interest in the reputational and decisionmaking case studies has spread to England, although few studies have actually been concluded. The reputational approach is based on the assumption that those who have a "reputation" for having and exercising power are in fact the powerful. The one major study conducted in England used this approach (Miller's study of Bristol). The third approach using specific issue decisions, according to who participates in the process, assumes that in fact leadership consists of such active participation, and that there are various community power substructures by issue areas. But these more sophisticated, or at least more recent, methods would seem to miss the mark in Britain.

The decision-making process in a city is substantially contained within the official structure. In "City Politics in Britain and the United States,"(Political Studies, London, June, 1969), K. Newton 
makes an important comparison. The selection of methodology for identifying community power can be predicated upon the elements of his comparison.

In an American city, power is fragmented and dispersed. The executive and legislative functions are generally separated. Newton quotes Banfield as saying the politician is a kind of broker working out terms to bring bits and pieces of legal authority together into a public policy. In Britain, power is more concentrated, at least formally, and is more uniform and consolidated. This creates a fundamental difference in political style.

Newton notes that much of the American literature on community power structure is simply an analysis of how certain people or groups collect support to overcome resistance or inertia or to block moves. "...such an account of the politics of most British cities would not be in the main or even the most significant story." American litera-. ture is not irrelevant, but some American questions are less important in British politics where politicians play "rather more of an executive role, and where the problems of mustering sufficient support in the community to overcome the widely spread powers of veto groups are less acute. ${ }^{2}$

Part of the explanation lies in the council organizational differences. Most American cities have a weak council of five, seven, or nine (Chicago is unique with 50). With so few city councilmen, most pressure groups can work informally. In Britain, on the other hand, the average is 57 councillors. Hence, there aŕe more groups represented on the council itself. The major established pressure groups can use their 
own people and need not lobby so obviously. Parties are also more unified and stronger, and have more direct influence. ${ }^{3}$

Miller's work in Bristol is the only comparative study between English and American city power structures, and it uses the reputational approach to study Bristol (U. K.) and Seattle (U. S.). Hunter first applied this technique to the study of city politics, and Miller is thus enabled to include Hunter's work in Atlanta, Georgia, in his comparisons. Miller found that Bristol was not run by key economic influentials (leading businessmen) which is a surprise for reputationists who have a tendency to discover pyramidal power structures dominated by the business elite. (K. I. means key influential).

English City (Bristol) does not look to its business leaders so much for civic leadership as do the two American cities. The business representation among the $\mathrm{K}$. I. in Pacific City (Seattle) is 67 per cent; in Southern City (Atlanta), 75 per cent; in English City, 25 per cent. The solution of civic problems is carried on more directly by the city council in English City, while voluntary organizations are more fluid and the solidarity of the key influentials is less in both English City and Pacific City than in Southern City.

In terms of citizen participation, the difference in city government structure is crucial. There is an apparent inverse relationship between concentration of power and citizen participation. This seems to be borne out in recent work by Michael Aiken at the University of Wisconsin. He constructed a diffusion-of-power scale for 31 American communities that were the subject of decision-making studies. This scale is "related to community participation in four Federal self-help programs--public housing, urban renewal, Model Cities, and the war on poverty. The results show that the cities in which power is most diffused have greater participation in these programs." 5 
The pattern in England fits Aiken's thesis. Power is concentrated in the hands of elected public officials and there has been little citizen involvement. An increase in local pressure group activity, however, may portend some change.

\section{British Pressure Groups}

Until recently, outside the party structures, there was hardly any pressure-group politics in local government except the teachers, the churches, council tenants associations, ratepayers, and on rare occasion the Chamber of Commerce or Trade Council.

This could scarcely be because there are no groups, for local associations flourish in abundance in this country. But they seem to have exercised a self-denying ordinance and the local council has been viewed as something remote and unassailable, concerned with that dreadful thing called "politics," which no self-respecting voluntary body wants to get involved in. How else explain the indifference of the business community and its various clubs and groups to the considerable powers which local planning authority has over the pattern of 1 and use in its area? ${ }^{6}$

In the past decade or so, spectacular growth has taken place in local pressure groups. However, there is a difference in the approach of British interest groups. American groups are more prone to public campaigns aimed at the legislative process, or the electorate. In Britain, the interest groups are more likely to concentrate on building good will and good relations in general, and influencing executive and administrative arms of the British Government in particular. This takes the form of consultation and negotiation at both the national and local levels. Local government co-opts interest representatives onto official committees in some cities. Generally, the lobbying process is more in the "very heart of the executive process" and the pressure 
group activities are, hence, less visible.

A related observation is that interests can be more easily reconciled in Britain because of the smaller number of social and political lines of cleavage--mainly class. In the United States, cleavages of religion, ethnic origin, color, and regional culture are added to class cleavages.

In America, each separate issue often has a separate pressure group. Single purpose groups may form temporary coalitions but retain their identity. In Britain, the all-purpose group is more important. There is a tendency of interest groups to get the well-established al1-purpose group to take up their issue. Such al1-purpose groups are the Chamber of Trade or Commerce, acting for middle class and business interests; and the Trades Council, acting for the working class. 8

There is also a tendency to direct attention toward the nationwide influence of pressure groups. The centralized political system naturally emphasizes the national pressure group. Another reason is the lack of study of local pressure groups, so that it is not clear what they really do accomplish. Lack of knowledge on this subject is partly due to low visibility of the activity, but it may be the case of the iceberg below the surface of the water.

The Civic Trust

In the forefront of the effort to give people their voice is The Civic Trust. It is an action organization on a modern model but with historic antecedents. In the $1860^{\prime} \mathrm{s}$, the spread of London was placing open 1 and (the commons) in jeopardy, and the first of the important voluntary groups came into being as the "Commons, Open 
Spaces and Footpaths Preservation Soeiety" in 1965. The Society was inaugurated by John Stuart Mill, T. H. Huxley, Octavia Hill, and Robert Hunter, among others, to fight the enclosure of common lands. In 1877, the "Society for the Protection of Ancient Buildings" was founded by William Morris. Octavia Hill and Robert Hunter in 1895 helped to found the "National Trust." The National Trust came out of a struggle to safeguard the Lake District for public use, and by acquiring land as a means of saving it, the National Trust became one of the major 1 andowners in the country. By the end of the century other organizations had come into being, including the "Metropolitan and Public Gardens Association," the "Society for Checking Abuses of Public Advertising," and the "Garden Cities Association." The successor to the Garden Cities Association was the Town and Country Planning Association, which was responsible for promoting Welwyn, Letchworth, and the many new towns which are now the trademark of Britain.

In the 1920's the English countryside began to suffer from ribbon development and unplanned town growth. This became the rallying point for "the amenity movement" and many societies were formed. The Council for the Preservation of Rural England resulted, and it established county branches. The movement was strong through the 1930 's until the war interrupted progress.

The towns, however, did not stir as much interest as the countryside, and there were only a handful of societies that were struggling to improve urban amenities. Only Bristol, Bath, Birmingham, Edinburgh, London, Norwich, Newcastle, and Stafford had such societies. At the outbreak of World War II there were about 100 local amenity societies 
in existence. As the war ended, however, more sprang into existence. In the late forties and early fifties, local societies came into existence at the rate of about 10 per year. Nearly all were in South East England, because this was where the pressure of growing population was felt most. By 1957 the societies numbered about 200. The creation of The Civic Trust with its technical staff and program of sending speakers, making grants, and championing local causes, rallied the civic society movement. "After that, the aim was not just preservation "but the improvement of existing urban and rural fabric," 10 The Civic Trust is today a major exponent of citizen participation, and is a conduit for the participation of many.

\section{$\underline{\text { Reform }}$}

It is difficult to separate cause and effect in the gathering storm over citizen participation. There were several phenomena related to causes: (1) The Labour Party had been pressing for a program of increased flow of information from management to the shop floor. Pressure for more openness did not carry through necessarily to the Labour Party Government, but was a part of the overall picture. (2) The Fulton Report on the Civil Service opted for radically greater openness in the conduct of governmental affairs. (3) The Maud Report was partly aimed at "the abominable record of poor participation and gross secretiveness of much of local government." 11

The Consumer Association has grown more rapidly than any other voluntary organization in most recent years. "Other associations devoted themselves to the advancement of state education, the welfare of hospital patients, the building of cooperative housing, the 
improvement of public transport, and the preservation and enhancement of the rural and urban scene. Participation became a word to conjure with in Britain, as it also was in France and the U. S. A."12

But, why have these movements occurred? L. S. Sharpe provided some insight in the April, 1966, issue of The Political Quarterly (London).

Peggy Crane, who was one of the first to notice this phenomenon, has suggested it is associated with the crumbling of old group and communal loyalties due to greater social and geographic mobility combined with a growing sense that the individual feels himself unable to exert any direct influence on the conduct of government through the normal channels. It reflects "the tendency to emphasise the individual as distinct from the mass organisation... the wish to do something practical in a limited sphere rather than see it as part of a drive to change the values of society." Maurice Broady sees it as essentially a result of the growth of the intellectual middle class which, dissatisfied with many of the statutory services, has set up its own organisations to press for improvement or to provide the service on a voluntary basis. "...this growing critical minority in modern Britain, unwilling to tolerate the slowness and the caution with which local councils tend to move, unwilling to spend years in the lower eschelons of political party machines waiting for influence, have been organising independently in voluntary bodies where for all their lack of resources, it is sometimes possible not only to pioneer new developments but also to represent the consumer interest more easily and more congenially."13

The Political Quarterly (London), in its October, 1968, issue on

"Participation, Priorities and Planning" analyzed the situation thusly:

Behind all these stirrings four motives seem to emerge: political opportunism or necessity; belief that it is right, as a democratic principle, to increase participation; a belief that increased participation and communication further economic efficiency and productivity; and a doubt whether traditional methods of elected representation--as seen in the House of Commons and in local councils--can do the job alone. 14

The authors of another article, Peter Levin and David Donnison, in Public Administration (London), Winter, 1969, saw a changing political climate for planning because of a belated realization that 
the Welfare State had not eliminated the main social injustices toward which it was directed. 15

A Government White Paper entitled Town and Country Planning was issued in June, 1967, and brought the agitation to a head:

Three major defects have now appeared in the planning system. First it has become overloaded and subject to delays and cumbersome procedures. Second, there has been inadequate participation by the-individual citizen in the planning process and insufficient regard of his interests. Third, the system has been better as a negative control on undesirable development than as a positive stimulus to the creation of a good envi ronment. 16

The recommendations in the White Paper were embodied in the Town and Country Planning Act of 1968, which called for public discussion of planning decisions before finalization. Before the Act was actually passed, a Committee on Public Participation in Planning was appointed, taking its name from its chairman, A. M. Skeffington, MP, Joint Parliamentary Secretary, Ministry of Housing and Local Government. The Skeffington Committee was given the task of considering how to keep the commitment of the proposed legislation for public participation in planning. 17

The main recommendations of the Report were as follows:

1. People should be kept informed throughout the preparation of a structure or local plan for their area. The structure plan is the basic plan document against which all specific plans and detailed 1 and use regulations are to be formulated. People have not in the past had incentive to check planning at that stage, but rather only when a specific plan affected their interests. .

2. In addition to continuous consideration, there should be set pauses to give a positive opportunity for public reaction. 
3. Where there are alternative choices, the authorities should put them to the public, asking preferences.

4. Planning authorfties should set up community forums to provide local organizations with the opportunity to collectively discuss planning and other key local interests, also distributing information on planning matters and promoting formation of neighborhood groups.

5. Community development officers should be appointed to secure the involvement of people who do not join organizations.

6. The public should be told what their representations have achieved or why they have not been accepted.

7. People should be encouraged to participate, helping with surveys and other activities, as well as by making comments. 18

Levin and Donnison called the Skeffington report "both important and inadequate" and "only a beginning." The Committee did not seriously consider the possibility, according to the authors, that participation would lead to frustrating action--seeing participation as only leading to understanding, consensus, and constructive action. But understanding does not "inevitably lead to good will and agreement." Levin and Donnison implied that it works better and just as democratically for the professionals to be accountable to elected watchdogs alone. They acknowledge that it is naive to assume that professionals have no interests of their own at stake, however. "They do not simply seek constructive action: they want visible achievements recognizably due to their own effort and skill." 19

Notwithstanding such doubts within the planning profession, the 
Skeffington Report and the Town and Country Planning Act of 1968 have been greeted with general approval.

\section{Development Areas}

Despite the increasing demand for citizen participation and awareness of the need for environmental protection, the author was surprised at how little the impact has been on economic development programs. For example, the main Civic Trust concerns, especially in the Development Areas, are only for the general appearance of the industrial areas. Sir William Mather, Chairman of The Civic Trust for the North West, said at a York conference:

An interest in the Civic Trust grew out of a sense of outrage at the appearance of our surroundings. The most squalid concentration of industry in the world is in Lancashire. It seems to be the height of inefficiency to live in such squalor and to do nothing about it. Atmospheric pollation seems intolerable and unnecessary and the initiative of $\frac{2}{20} 0_{\text {indiduals }}$ had greatly improved the position in Manchester.

The Director of The Civic Trust for the North East, when asked what role his organization played in the location of industry, implied that it played a very small role. He said in his letter of April 22, 1970:

Here in the North East the Trust is chiefly concerned in ridding the region of the effects of 19 th century industry and bad urban development, to clear dereliction and squalor which exists in too much of the region, and trying to seek ways in which working industry itself, particularly of the older basic varieties, can be visually improved. 2

The matter of industrial location is largely left to the local authority planner and to the Department of Trade and Industry and other government officials. Questioning by the amenity societies does occur, but it is not their primary concern. 
For example, in a booklet prepared by the Nature Conservancy for the European Conservation Year 1970, local authorities were asked to concern themselves with a number of activities and policies, including the following:

Encourage your staff to stimulate as much public participation as possible on the lines advocated in the Skeffington Comnittee Report on Public Participation in Planning.

Promote joint research, survey and experimental action with voluntary organisations to provide the information needed to decide your policy.

Stimulate inftiatives by volunteer groups to clean up, restore or beautify areas.

Review the use of all publicly owned property, for example, public parks. Try to provide more varied natural habitats and opportunities for greater enjoyment. Establish voluntary wardening schemes where necessary. Also review with those responsible the management of publicly owned property in private use, e.g., estates, sma11-holdings, residential areas, school grounds.

Promote close and continuous co-operation between 1 andowning, industrial, agricultural, forestry, cultural and conservation bodies in your area, for example, through Countryside Committees, Sub-Committees or Panels.

Aim for the highest standards of design in all buildings, car parks, outdoor furniture and signposts. 22

No mention is made of the location of industry and I believe that omission to be significant.

\section{Conclusion}

One must conclude, although it was not the original hypothesis of this author, that there is relatively little general citizen participation in economic development in Great Britain. There are no formal or informal economic development committees in the official program; there is little apparent citizen contact with decision-makers through 
the amenity groups on this subject. Not only is there no effort on the part of amenity societies, but there is very little influence exercised on location of industry by business groups directly.

In Development Areas, at least judging by the Northern England region, everyone seems agreed that economic development is necessary and is to be given an extremely high priority. Decisions are regarded as the province of local authority planning offices and central government agencies. The newspapers in Northern England are strongly supportive of industrial development and rel ated government programs. Great coverage is given to industrial development matters, business and industry. Conversations with people in many vocations disclosed widespread awareness of economic development needs and progress--but a feeling that it is the job of the officials to produce results. The major outside influence on decision-making comes through the party organizations, apparently. In Northern England, Scotland, Wales, and most other Development Areas, the Labour Party dominates. It can, therefore, be presumed that the major priorities and policy alternatives are adopted according to major party orientation.

The working people are the chief victims of unemployment problems. Working people therefore are the chief beneficiaries of programs to solve unemployment. Through working class votes the Labour Party controls local government in most areas where unemployment is of greatest concern. Therefore, so long as local government carries out aggressive economic development policies, it is unlikely that the Labour Party, local or national, will willingly interfere on aesthetic grounds (amenity interests) or on the basis of demands for more direct 
democracy (citizen participation). Change is in the wind, but it will be slow, and change will proceed even slower in the economic development process because of the area priority given to creating economic expansion. But, if experience in the U. S. is any basis for judgment, the British, too, will soon be giving environment and citizen participation more attention in $\mathrm{DA}^{\prime} \mathrm{s}$. 
$1_{K}$. Newton, "City Politics in Britain and the United States," Political Studies (London), Vo1. 27, No. 2, June, 1969, p. 210.

2 Ibid.

3 Ibid., p. 212 .

${ }^{4}$ Delbert C. Miller, "Decision-Making Cliques in Community Power Structures: A Comparative Study of an American and an English City," American Journal of Sociology, Vol. 64, November, 1958, p. 307.

5 Michael Aiken, "Community Power and Community Mobilization," The Annals of the American Academy of Political and Social Science, Vol. 385, September, 1969, p. 76.

6 K. Newton, p. 212 .

7 Ibid., p. 213.

8 Ibid., p. 214 .

${ }^{9}$ The Civic Society Movement (London: The Civic Trust, 1968) pp. 3-4.

10

Ibid., pp. 4-5.

11 "Participation, Priorities and Planning," The Political

Quarterly (London), Vol. 39, October, 1968, pp. 358-59.

12 Peter Levin and David Donnison, "People and Planning," Public Administration (London), Vol. 47, Winter, 1969, p. 475.

${ }^{13}$ L. S. Sharpe; "Leadership and Representation in Local Government," The Political Quarterly (London), Vol. 37, April, 1966, pp. 156-57.

14"Participation, Priorities and Planning," p. 359.

${ }^{15}$ Peter Levin and David Donnison, p. 475.

16 The Civic Society Movement, p. 30.

${ }^{17}$ Committee on Public Participation in Planning, A. M. Skeffington, MP, Chairman, People and Planning (Lond on: HMSO, 1969), p. 1 .

18

Peter Levin and David Donnison, p. 476.

19 Ibid., p. 477. 
${ }^{20}$ Sir William Mather, "Conference Report: York Conference of Amenity Societies, 27-29 September 1968," The Civic Trust (London: Mimeograph, 1968), p. 6.

${ }^{21}$ Letter, Neville Whittaker, Director, The Civic Trust for the North East, Durham (City), April 22, 1970.

${ }^{22}$ The Standing Committee of The Countryside in 1970, European Conservation Year, United Kingdom (London: The Nature Conservancy, 1970). 
CHAPTER X

CONCLUSION

\section{Program Trends}

The British program is parent to the Appalachian Commission and the Economic Development Administration of the United States. Not unlike other parent-child relationships, we in America do not really know our British parent. In general, this study found the economic development program model across the Atlantic to be directly useful to program planning and analysis in the States, even though the British political model has 1ittle direct application. Even in political affairs, the trends in the two countries in the conduct of public matters are converging with respect to two items: citizen participation and planning.

The economic development programs of the two countries have had certain parallel phases, but with a time differential caused by the late American entry. There was much in common in the early phase, which can be called the "Job Development Era." Britain then followed with a phase which can be named the "Resource Development Era." America is still at this stage. Britain has advanced into the "Balanced Growth Era."

In the first two periods, various policies were tried and found wanting, or were further sophisticated, and a familiar pattern is apparent in the experiences of the two nations. Neither Congress nor 
the Administration is yet interested in the elements of a Balanced Growth Era, but this writer believes that in the end we will follow once again the lead of Great Britain.

\section{Job Development Era}

The initial thrust of both economic development programs was to get people onto jobs as quickly and surely as possible. A number of techniques were employed to do this, and both countries continue to place considerable emphasis on this answer to unemployment. The biggest pre-WW II problem in Britain was that area designations were confined to sma11 towns. After the war, development districts included the larger towns and gradually a policy evolved of working primarily with "growth areas." The essential goal remained that of producing a certain volume of jobs to employ the unemployed within commuting or short distance removal range. Table $X$ compares the dates during which each country emphasized or utilized this simplistic approach.

\section{Resource Development Era}

The Budget and Local Employment Act of 1963 amended and strenghened the 1960 measures in Britain, but more importantly, it was a turning point in the objectives of the program. The early programs had been emphasizing the social more than the economic aspects, concerned with providing jobs more than stimulating economic growth.

As the country's attention turned to producing an area economy that could generate jobs, it became "necessary to view the region as a whole rather than think simply in terms of unemployment blackspots."1 
TABLE X

JOB DEVELOPMENT ERA OF ECONOMIC DEVELOPMENT PROGRAMS

Program

Industrial Site Development

Custom Built Factories

Advance Factories

Retraining

Loans to Industry

Grants to Industry

Loans and Grants to

Local Government

Rapid Tax Amortization

(Depreciation)

Government Contracts to

Regions

National Commitment

to Full Employment
United Kingdom

1937 to date

1937 to date

1946-47;

1959 to date

1928 to date

1937 to date

1945 to date

1937 to date

$1933-66$

1937 to date

1944 to date

1946 to date

United States

1961-63;

1965 to date

1961 to date

1961 to date

1961-63;

1965 to date

1953-54

1952-65 (minor)

TABLE XI

\begin{tabular}{|c|c|c|}
\hline Program & United Kingdom & United States \\
\hline National Regional Policy & 1963 to date & 1965 to date (partial) \\
\hline Regional Controls on Location & 1947 to date & -- \\
\hline $\begin{array}{l}\text { New Towns, as Part of } \\
\text { Environmental Policy }\end{array}$ & $1946-55$ & $\begin{array}{l}\text { 1937-38; } \\
1968 \text { to date }\end{array}$ \\
\hline Resource Development Grants & $\begin{array}{l}1937-39 ; 1964 \text { to } \\
\text { date (via regions) }\end{array}$ & $\begin{array}{l}1965 \text { to date } \\
\text { (via regions) }\end{array}$ \\
\hline Derelict Land Grants & 1945 to date & $\begin{array}{l}1965 \text { to date } \\
\text { (Appalachia only) }\end{array}$ \\
\hline
\end{tabular}


The commitment to such an effort must be for the long term, too. It must be permanent enough to make planning possible, the kind of planning that the trend toward regional economic organizations ushered in.

Despite the energing regional economic development approach, program emphasis remained upon the use of incentives and controls to produce new economic growth in the troubled regions. Through this period the regions were still almost entirely dependent upon problem industries for their economic growth. Such might be a fair description of the status of the American EDA profram of 1972 , as wel1. Table XI compares the two countries in this era of economic development programming.

\section{Balanced Growth Era}

The dividing line between regional policy (optimum use of resources) and balanced growth policy is admittedly murky. Regional controls on industrial location, for instance, began in the chronological era characterized primarily by just creating jobs where they were needed. Yet, the motivation for the controls was partly to try to balance the economic growth of the country. Use of the I.D.C's is assigned to the second era, however, because the uppermost thought was to minimize the costs of severe regional unemployment, rather than to substantially alter the distribution of the national economy.

The chief characteristic of the third era, in short, is the recognition that area and regional economies may require restructuring in order to generate their own future growth. There had not been, prior to maturation of the regional boards and councils, the national commitment necessary to begin to alter regional imbalances. 
The vigor with which government proceeds is often more important than the methods used. Programs which distribute token grants and loans can help but are not sufficient to turn around a region's economy and eventually to benefit from the process of agglomeration--1inkages between supporting and related industry in a comprehensive industryservice complex.

The "balanced growth" attitude was not evident until the Labour Government in 1965 tooled up national planning and funding programs to inject public expenditure into selected growth points and infrastructure of regional importance. The commitment was made to alter the regional balance within the country, to create the infrastructure and the ability to self-generate new growth in the suffering regional economies, at the expense of further growth in the prosperous areas. The best example of the "balanced growth" attitude was the new purpose -for which new towns were ordered--their use as socio-economic tools to enhance regional development. They were no longer to be financed as "environmental toys" in open spaces outside London, still well within the region most likely to grow.

The early 1960 's saw movement toward regional economic thinking, but when the planning of regional freeways, airports, ports, etc., reached implementation stage with major new financing, the new era was entered. Table XII lists the more significant programs of the Balanced Growth Era.

As the REP and SET programs falter, it seems that,Britain is backing away from the tax incentive route to balanced growth. Otherwise it is interesting to see that the United States has followed Britain's 
TABLE XII

BALANCED GROWTH ERA OF ECONOMIC DEVELOPMENT PROGRAMS

Program

Regional Counc1ls and Boards

New Towns, as Part of Socio-Economic Policy

REP (Regional Labor Subsidy

Payments to Industry)

SET (Tax Reduction by Region)
United Kingdom

1965 to date

1961 to date

1967 to date ${ }^{*}$

1968 to date*
United States

1965 to date (partial)

* Both the REP and SET are being phased out by the Conservative Government in the 1970's.

lead after Britain itself has tried some policies and then found them wanting. We have now had the same experience and rejected or modified them. The area designation policy is a case in point, with the most recent change by Congress extending the time period of eligibility of areas to a minimum of three years, in 1971 amendments.

The key British policies which seem almost certain to come in the States are the use of new towns as economic development tools and the effort to achieve regional balance to take the strain off the metropolitan areas and build up viable smaller population areas. "Smaller" population areas are not to be confused with "rural" areas, though they may be the same in some instances. Growth centers are already being selected over time through multi-county planning programs and regional commissions, as well as state governments. The important growth centers are most likely to have a present population of 25,000 or 50,000 people. There will be recognition that some have the potential for several times their size at less public investment cost than either 
expanding rural areas or expanding metropolitan areas. Except for some rhetoric, however, we have not yet in this country embarked upon a determined policy of this nature. It could be that the United States will be slow to make a full commitment, and it may even be that Britain will recede from their policy commitment for a time. But, it is the view of this writer that within a few years both nations will be extensively committed to the objectives of a Balanced Growth Era.

\section{Location Controls}

The Special Areas program of the 1930 's did not affect unemployment much. It did have significant research and experimental value. McCrone concludes that the absence of controls on development elsewhere in the country made it difficult for the program to succeed. America can be expected to reach some such conclusion, whether or not a comparable program of location controls is adopted. It is not 1ikely that an orderly national control mechanism will be directly imposed in the United States. More likely it will be a hodge podge of controls established for other or related purposes, such as environmental control, which will in a great reform sweep be re-ordered into a national policy. The author's estimate is that within five years we will have some sort of information gathering system that will enable us to do a better planning job and also evaluate both the problems and the programs extant. The sales-talk, however, will be environmental protection, not economic development. The result could be more effective economic development programming on the basis of conscious policy, or the result could simply be a larger investment in urban development, irrespective of balanced growth policy. The crystal ball clouds. 
New Towns

The New Town movement in Britain has always been interesting pioneering, but only in this past decade has it made a significant contribution to human welfare. The movement in the States, if it can be called that, gives almost no promise of growing beyond the "interesting"stage. To promote new towns outside the framework of state and regional economic planning is not only useless, but probably damaging to 1 ong-term planning, and a waste of the public and private resources expended. If the developments can be made to turn a profit, they can be applauded perhaps. If they are to serve other purposes, then we have a lot to learn.

Some U. S. planners and officials figure new town planning into solutions to our ghetto problems, including racial tension. In light of this thinking, it is informative to read Britain's writers as they comment on the racially homogeneous new towns in the U. K. J. Brian McLoughlin, in the November, 1966, issue of the Journal of the American Institute of Planners, said:

Whether in new towns, town expansions, publicly sponsored overspill schemes, or in new private housing developments at the periphery, these very large redistributions of population produce massive shifts in regional and national human ecology. It is doubtful whether these processes are properly understood.... Until the recent exercises in the production of regional strategies for population redistribution, there has been a tendency to discuss proposals in isolation. There is still little evidence of any attempt to quantify the more important repercussions of 1 arge shifts in population on employment, traffic flows, transit use, shopping centres, recreational demands, and so forth. Also there has been little evidence of any comparative evaluation of alternative sets of strategies within a social costs and benefits framework. ${ }^{2}$

If there has been significant progress since McLoughlin wrote 
his 1966 article in analyzing the impact of large shifts in regional human ecology, it is not obvious. Even in terms of mixing economic levels, nobody seems to have found the "open sesame." James Dollan reported in The New Statesman of March 10, 1967, that the planners of one of the recent new towns, Washington in County Durham, proposed to integrate the economic levels throughout the town by mixing rentals and sales and low, medium and high-cost houses. Dolan adds:

What nobody questions is the bravery, the blind faith (or even something less complimentary) in the ideas they have in mind for the kind of housing, which Washington New Town is to get.

The postcript is sad. When this writer visited Washington New Town in October, 1969, the enterprising general manager, Mr.. Holley, had still not been able to move toward neighborhood integration, although in nearly all other respects the reality of Washington $N$. T. seemed to give promise of matching the dreams of the planners. Americans could learn from the British in their new tow experience, if we would assign less weight to the obvious differences in system and customs.

\section{Regional planning}

Even allowing for the differences in system with respect to the Regional Councils and Boards of Britain, this author cannot believe that the best regional staffing is by central government civil servants. Whatever else may be different in our two countries, surely the bureaucratic instincts of central (federal) government senior personnel are not that different. A man cannot truly serve two important masters, London as well as the adopted (assigned) region in which he is hoping 
to serve only a part of his career. The political and economic problems of a region too of ten call for answers which are at variance (or an embarrassment) to national policies and goals, not to mention those instances where parochial regional attitudes and tendencies are the problem.

Further, there is no way to show results from advising the central government, so long as the pipeline to the government is controlled by central personnel. It will be even more difficult now with the Labour-dominated areas "advising" the Conservative Government. Regional advocacy is crippled where there is no place for the Member of Parliament in regional planning, where there is no provision for regional MP meetings and no mechanism of communication and negotiation. There should be.

To overcome these shortcomings, regional councils should have their own staff, an independent budget (money is the best coordinator among competing jurisdictions and projects) and a political role to play. The Maud Report recommends provincial bodies. It seems a good idea; they would likely become more effective advocate bodies than in the present system. The opponents of this plan are likewise convinced, but fearful, that provincial bodies would be better advocate organizations, of course.

\section{Citizen Participation}

There are significant differences between the two countries in citizen participation in local governmenț. We make extensive use of citizen committees in the U. S. in all manner of advisory capacities, albeit most are blue ribbon power structure or special interest 
representatives. We also make greater use of the vote of the people on bond issues, forms of taxation, and tax rates, budgets, and referendum and initiative on other matters. Young people in the U. S., and a growing number of more aged Americans, are demanding still more direct democracy. But the English would consider most subjects, other than election of their representatives, inappropriate for direct ballot action and most decisions as appropriate only for officeholders.

Despite the Skeffington Report in Britain, and some obvious changes in planning approval system, we should not anticipate any major increase in citizen participation under the Conservatives. Their tendency is to fear the "triumph of selfish interests and...general ineffectiveness," which they believe attends self-government in too pure a form. ${ }^{6}$ This traditional political attitude will be reinforced by the technician's reluctance to have his plans changed by untrained members of the public. The Conservative Party history of reliance on "those qualified to govern" will surely not be displaced by excessive direct citizen participation.

In the Development Areas, moreover, American-style community committees with a "mix" of economic interests are also an unlikely tactic, though no more unlikely under the Conservatives than under Labour. Perhaps after a time out of office, Labour will more strongly espouse the principles of the Skeffington Report.

Summing up the role of the citizen in the British economic development program, the following characteristics can be emphasized:

(1) Very 1ittle citizen participation.

(2) Little effort by amenity societies to affect location of 
new industry.

(3) Very little community influence exercised by business.

(4) Nearly everyone is agreed--especially in the DA's--that economic development is necessary and is to be given highest priority.

(5) Decisions on industrial location and economic development are regarded as quite properly the province of local authorities, planning officers and central government agencies.

(6) Development Area newspapers and government prose reinforces this attitude and keeps the need for economic development in the public eye so that it is by far more "acceptable" to help than to hinder, either by environmental or economic counter-argument.

\section{Degree of Commitment}

As has been pointed out several times, the British are spending a good deal more of their national provender on balancing their regions economically than we are in this country. This comparison can be made Irrespective of which political party controls in Great Britain.

There has been, of course, a difference in commitment between the Labour and Tory Parties. Labour claimed a substantial difference in regional assistance to industry to prove their zest for the program. In 1963-64, the Conservatives spent 76 million pounds, which was $0.28 \%$ of Gross National Product and $0.63 \%$ of total governmental expenditures. In $1968-1969$, Labour spent 835 million pounds, $2.3 \%$ of GNP and $4.3 \%$ of total governmental expenditures. This was the greatest increase of any area of government spending and, except for Social Security, the greatest absolute increase in expenditure. There were major increases also in housing and health and education under Labour while defense and 
agriculture declined.

Regional policies were under pressure by late 1970 and 1971

because of increasing hard times. Brian White described the continuing dilemma of the lagging regions in an article for the Manchester

Guardian Weekly, November 28, 1970, commenting on governmental policy to combat inflation:

Officially the regional development organisations are optimistic about their ability to withstand a renewed freeze with more resilience than in the past. But as a comparison of regional unemployment over the past decade shows, the gap between the depressed areas and relatively prosperous areas is still vast. Moreover there is still a strong tendency for the disparity of unemployment between regions to grow as the national average increased. ${ }^{8}$

$\begin{array}{cc}1960 & 1969 \\ \text { Per Cent } & \text { Per Cent }\end{array}$

U. K.
North
Yorks. \& Humberside
E. Midland
E. Anglia
South East
South West
North West
South Wales
Scotland
No. Ireland

$\begin{array}{ll}1.7 & 2.5 \\ 2.9 & 4.8 \\ 1.0 & 2.6 \\ 1.0 & 2.0 \\ 1.0 & 1.9 \\ 1.0 & 1.6 \\ 1.7 & 2.7 \\ 1.9 & 2.5 \\ 2.7 & 4.1 \\ 3.6 & 3.7 \\ 6.7 & 7.3\end{array}$

Source: Brian White, "A Grim Outlook in Regions," Manchester Guardian Weekly, November 28, 1970, p. 9.

The Conservatives described Labour's policies as a "waste of money" but this was chiefly campaign oratory. 9 After some curtailment and change of emphasis from broad subsidies to particularized assistance, the Conservative Government restored vigor to the regional programs in 1972.

The budget in 1971 set aside 170 million pounds for industrial 
and regional assistance, but in March, 1972, the Chanceilor of the Exchequer projected a build-up in regional spending to a massive 1,000 million pounds a year by 1975. 1972 spending would be at 500 million pounds, with 300 million pounds for new regional incentives and around 200 million pounds for selective assistance grants and loans from the new Industrial Development Executive of the Department of Trade and Industry. In the last full year of the Labour Government program 250 million pounds was paid out in investment grants.

Despite differences in financial commitment between the parties in Britain, the Americans are not in the same league at all, as Table XIII amply demonstrates. In fiscal year 1970 (approximately the same time period in both countries) the United States spent $\$ 3.97$ per capita in development area economic development programs, contrasted with $\$ 58.70$ per capita in Britain. The U. K., therefore, outspent us 14.8 to 1 . Expenditures in Britain, and population estimates in Development Areas, are shown in Tables XIV and XV. 
TABLE XIII

ECONOMIC DEVELOPMENT EXPENDITURES-U. S. VS. U. K.

FY 1970 (converted to dollars)

\begin{tabular}{ll} 
Program & Total \$'s \\
Expenditures & Expenditures \\
Econ. Dev. & Econ. Dev. \\
$(000)$ & $(000)$ \\
\hline
\end{tabular}

Population of Areas

Served

$(000)$

Unted States

Public Works

Business Loans

$\$ 157,896$

49,360

Tech. Assistance

14,670

Planning

$\$ 232,161$

58,436

United Kingdom (pounds)

Factory Building

Loans to Industry

10,235

$$
\begin{array}{r}
15,882 \\
18,433 \\
1,073 \\
21,477 \\
1,608 \\
224,708 \\
\hline 283,181
\end{array}
$$

Building Grants

Plant \& Mach. Grants

Inves tment Grants

FY 1970: U. S. July 1, 1969, to June 30, 1970.

U. K. April 1, 1969, to March 31, 1970.

Sources: Department of Trade and Industry (letter dated September 1, 1971)

Economic Development Administration, Jobs for America, Annual Report Fiscal 1970 (Washington, D. C.: U. S. Department of Commerce, Government Printing Office, December, 1970) and Directory of Approved Projects, As of June 30,1970 (as above) and Qualified Areas, Criteria and Data (as above).

Estimates of population in British Development Areas were obtained unofficially from sources in the Government. 
TABLE XIV

TOTAL ASSISTANCE (LOCAL EMPLOYMENT ACTS 1960-1966)

Gross Figures Excluding Investment Grants--1962 - 1968

\begin{tabular}{|c|c|c|c|c|c|}
\hline $\begin{array}{l}\text { Year (Apr. } 1 \\
\text { - Mar. 31) } \\
\end{array}$ & Country & $\begin{array}{l}\text { No. of } \\
\text { Projects }\end{array}$ & & $\begin{array}{l}\text { Amount } \\
(000)\end{array}$ & $\begin{array}{l}\text { Est. Em- } \\
\text { ployment }\end{array}$ \\
\hline \multirow[t]{2}{*}{$1962-1963$} & $\begin{array}{l}\text { England } \\
\text { Wales } \\
\text { Scotland }\end{array}$ & $\begin{array}{l}48 \\
11 \\
77\end{array}$ & 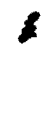 & $\begin{array}{r}10,639 \\
397 \\
5,038\end{array}$ & $\begin{array}{r}20,400 \\
800 \\
5,900\end{array}$ \\
\hline & Total & 136 & & 16,074 & 27,100 \\
\hline \multirow[t]{2}{*}{$1963-1964$} & $\begin{array}{l}\text { England } \\
\text { Wales } \\
\text { Scotl and }\end{array}$ & $\begin{array}{r}250 \\
24 \\
209\end{array}$ & & $\begin{array}{r}15,173 \\
635 \\
14,403\end{array}$ & $\begin{array}{r}22,300 \\
1,000 \\
18,500\end{array}$ \\
\hline & Total & 483 & & 30,211 & 41,800 \\
\hline \multirow[t]{2}{*}{$1964-1965$} & $\begin{array}{l}\text { England } \\
\text { Wales } \\
\text { Scotland }\end{array}$ & $\begin{array}{r}479 \\
29 \\
463\end{array}$ & & $\begin{array}{r}24,227 \\
1,205 \\
15,176\end{array}$ & $\begin{array}{r}36,765 \\
2,088 \\
21,390\end{array}$ \\
\hline & Total & 971 & & 40,609 & 60,243 \\
\hline \multirow[t]{2}{*}{$1965-1966$} & $\begin{array}{l}\text { England } \\
\text { Wales } \\
\text { Scotland }\end{array}$ & $\begin{array}{r}574 \\
89 \\
587\end{array}$ & & $\begin{array}{r}23,060 \\
3,665 \\
15,588\end{array}$ & $\begin{array}{r}43,838 \\
6,389 \\
42,267\end{array}$ \\
\hline & Tota1 & 1,250 & & 42,313 & 92,494 \\
\hline \multirow[t]{2}{*}{$1966-1967$} & $\begin{array}{l}\text { England } \\
\text { Wales } \\
\text { Scotland }\end{array}$ & $\begin{array}{l}722 \\
201 \\
778\end{array}$ & & $\begin{array}{r}27,048 \\
8,840 \\
19,543\end{array}$ & $\begin{array}{l}37,076 \\
12,979 \\
36,128\end{array}$ \\
\hline & Total & 1,701 & & 55,431 & 86,183 \\
\hline \multirow[t]{2}{*}{$1967-1968$} & $\begin{array}{l}\text { England } \\
\text { Wales } \\
\text { Scotland }\end{array}$ & $\begin{array}{l}717 \\
224 \\
756\end{array}$ & & $\begin{array}{r}20,150 \\
8,646 \\
17,643\end{array}$ & $\begin{array}{l}28,750 \\
13,260 \\
25,394\end{array}$ \\
\hline & Total & 1,697 & & 46,439 & 67,404 \\
\hline \multirow[t]{2}{*}{$1968-1969$} & $\begin{array}{l}\text { England } \\
\text { Wales } \\
\text { Scotl and }\end{array}$ & $\begin{array}{r}1,060 \\
406 \\
948\end{array}$ & & $\begin{array}{l}25,478 \\
11,859 \\
17,364\end{array}$ & $\begin{array}{l}38,004 \\
14,558 \\
22,572\end{array}$ \\
\hline & Tota1 & 2,414 & $\xi$ & 54,701 & 75,134 \\
\hline
\end{tabular}

Source: Board of Trade, Mimeograph, 1969. 
TABLE XV

POPULATION IN DEVELOPMENT AREAS AND SPECIAL DEVELOPMENT AREAS

\begin{tabular}{lrrrrrrr} 
& \multicolumn{7}{c}{1965 to 1970} \\
Development Areas & 1965 & $\underline{1966}$ & $\underline{1967}$ & $\underline{1968}$ & $\underline{1969}$ & $\underline{1970}$ \\
\cline { 1 - 7 } & & & & & & & \\
Northern & 4953.1 & 5009.4 & 5026.6 & 5045.0 & 5052.8 & 5061.5 \\
Merseyside & 1749.2 & 1743.8 & 1744.4 & 1740.8 & 1741.4 & 1738.6 \\
South West & 422.4 & 432.6 & 436.1 & 439.1 & 441.5 & 442.8 \\
Wales & 1865.8 & 1877.0 & 1844.8 & 1890.8 & 1894.6 & 1899.9 \\
Winsford & 16.2 & 17.5 & 18.3 & 20.4 & 22.0 & 23.4
\end{tabular}

Special Development Areas

$\begin{array}{lrrrrrr}\text { Wales } & 616.6 & 613.1 & 610.9 & 608.4 & 605.8 & 605.1 \\ \text { Workington }{ }^{\text {Nor }} & 143.7 & 144.0 & 144.0 & 143.7 & 143.0 & 142.2 \\ \text { North East } & 1604.4 & 1655.9 & 1660.3 & 1665.0 & 1668.1 & 1664.0 \\ \text { ** } & & & & & & \\ { }^{*} \text { Cumberland } \\ *{ }^{*} \text { County Durham and Northumberland }\end{array}$

Source: Figures are not published for $\mathrm{DA}^{\prime} \mathrm{s}$ and SDA's because such areas are defined in terms of Employment Exchange Areas, wheras estimates of population are made only for Local Authority Areas and these do not always colncide exactly in boundaries. Therefore, the above figures were obtained unofficially from knowledgeable sources in the Government (communication dated September 8, 1971).

\section{General Conclusions}

It can be said that Britain's economic development program suffers for its total "top-down" orientation. It appears to lack the local innovation which has produced many fine projects and successful bootstrap programs in the U.S. It is doubtful that innovative projects not normally considered in a national priority category would get the attention which they do by the less structured Economic Development Administration. For instance, the Oregon Shakespearean Theater or the Yaquina Bay Marine Science Center in the author's own State of Oregon 
were not in any national blueprint for cultural or scientific development. They were approved by EDA (and its predecessor, ARA), however, because of the local impact they would have on distressed community economles, as well as their inherent merit. In addition to innovative public facility projects in the U. S., some business enterprises sponsored locally would not have received a helping hand in the British style economic development program.

However, any shortcomings in this regard are compensated for handsomely in a comparison of the programs of the two countries by the quality of the incentives offered in Britain, as well as by the quantity. Grants to industry, along with Industrial Development Certificates, are the wheelhorses of the British program, and both are unknown in the U. S. program. Without either of them one could assume that the incentive to leave South East England would not be nearly enough to affect redistribution of industry.

As the bitterness of class conflict recedes, if it does, one can look for more sectionalism in British voting patterns. This could affect in either direction the "balanced growth policies" of the country. If the Conservative Party ignores the plight of the Development Areas, their regional allegiance to Labour would be fortified and many of the 1970 voting defectors could be restored to Labour. On the other hand, it is difficult to see what could fortify or expand Conservative Party dominance in the Midlands. It is 1ikely that this political assessment encourages the Conservative Party to continue to provide some, if not enough, help to the distressed regions. Whatever possibility the British have of significantly affecting 
regional imbalances, the United States has much 1 ess chance to do so. First, the task might require even more resources proportionately than the British, who must indeed pay a high price. Second, there is not the determination in the U. S. to try. Different re-orderings of national priorities are currently favored by various political groups but the reformers are more concerned with ecology and large city problems than regional problems.

The Nixon Administration is interested in slowing or halting migration to the large cities from non-metropolitan areas, but the feasibility and price of totally reversing the present strong trends have not been assessed.

Perhaps it is the writer's subconscious desire to rema in in his present work, but he believes that what the Economic Development Administration is doing is worthwhile, even if not calculated to achieve actual regional balance. Increasingly, EDA is popularizing economic planning and community capital programming to meet 1 ong term needs, and that alone is a worthwhile service. But, a more effective set of tools to stimulate regional economic development would be preferable.

Before this study was launched, the following statement was written:

In the United States we place great emphasis on local planning and participation and project initiation. But Great Britain appears to place little reliance on local participation, at least in official terms. It is essentially a national program, with increasing regional planning input.

To my knowledge, there are no published materials that stress the actual local workings of the economic development process in Britain, but I expect that there is some significant local role. Just what it is, who is involved, how much local 
influence is possible and how is local planning affected, are questions I would like to pursue by some on-the-spot interviewing, supplemented by related research....11

Right....right....right.... and wrong! The British program is essentially a national program. There are no materials on local workings of the system. There is a significant local role about which 1ittle is known. But, the author was wrong in believing that the citizenry and community organizations have any noticeable impact on the program. Nonetheless, local government in County Durham demonstrated that it is an effective, if junior, partner in the British system of economic development for lagging regions. 
${ }^{1}$ Gavin McCrone, Regional Policy in Britain (London: George Allen and Unwin, Ltd., 1969), p. 125.

2 J. Brian McLoughlin, "The Changing State of British Practice," Journal of the American Institute of P1anners, Vol. 32, November, 1966, pp. 350-55.

3 James Do1lan, "New Mixture for a New-Town," New Statesman, Vol. 73, March 10, 1967, p. 325.

${ }^{4}$ Royal Cormission on Local Government in England, Volume I. Report (London: HMSO, June, 1969), p. 17.

${ }^{5}$ Edward C. Banfield and James O. Wilson, City Politics (New York: Vintage Books, 1963), p. 77.

${ }^{6}$ Samuel H. Beer, Modern British Politics (London: Faber and Faber, 1969), p. 246.

7"Socialism v. Toryism--Where the Difference Shows," Economic

Brief, Labour Party of the U. K., Vo1. 3, No. 2, March, 1970, p.10.

8 Brian White, "A Grim Outlook in Regions," Manchester Guardian Weekly, November 28, 1970, p. 9. 1969.

"Heath: Tories Will Prune Subsidies," The Times, September 10,

10 "Real Hope for the Regions," The Times, March 26, 1972, Business News.

11 Tom Current, Prospectus for Thesis, June, 1969. 


\section{BIBL IOGRAPHY}

Advisory Commission on Intergovernmental Relations, Multistate Regionalism, A Commission Report (Washington, D. C., 1971).

Aiken, Michael, "Community Power and Community Mobilization," The Annals of the American Academy of Political and Social Science, Vol. 385, September, 1969.

Alonso, William, and Friedmann, John, Regional Development and Planning, A Reader (Cambridge, Massachusetts: The M.I.T. Press,1964).

Area, "The Recliffe-Maud Report," No. 4, 1969.

Banfield, Edward C., and Wilson, James O., City Politics (New York: Vintage Books, 1963).

Barstow, Tom, "Modernising the Town Hal1," New Statesman, February, 1966.

Beer, Samuel H., Modern British Politics (London: Faber and Faber, 1969).

Blackaby, F. T., Editor, "The Economic Situation--Annual Review," National Institute Economic Review (London), Vol.47, February, 1969.

Blackaby, F. T., Editor, "Summary," National Institute Economic Review (London), Vol. 49.

Board of Trade, Distribution of Industry Policy (Board of Trade, Distribution of Industry Division: Mimeograph, August, 1968).

Board of Trade Central office of Information, Government Help for Your Industries, Room to Expand (London: HMSO, May, 1968).

Board of Trade, Hotel Development Incentives (London: HMSO, May, 1968).

Board of Trade, Investment Incentives, Command No. 2874 (London: HMSO, January, 1966).

Board of Trade, The Movement of Manufacturing Industry in the United Kingdom (Lond on: HMSO, 1968).

Board of Trade and Central Office of Information, "Regional and Selective Employment Premiums, Advantages for Manufacturers in the Development Areas," pamphlet (Swindon: HMSO, May, 1968). 
Bostwick, Henry J., "The Industrial Park: What It Is--and Isn't," Nation's Business, September, 1969 (reprinted in "Economic Development," Vo1. 6, No. 11, November, 1969, Economic Development Administration, U. S. Department of Commerce).

Bracey, H. E., English Rural Life: Village Activities, Organizations and Institutions (London: Routledge \& Kegan Paul, Ltd., 1959).

Brown, Colin M., "Successful Features in the Planning of New Town Industrial Estates," Journal of The Town Planning Institute, Vol. 52, January, 1966.

Bu11, D. A., "New Town and Town Expansion Schemes," (Part I: "Assessment of Recent Government Planning Reports"), The Town Planning Review, Vol. 38, No. 2, July, 1967.

Burns, Wilfred, New Towns for 01d: The Technique of Urban Renewal (London: Leonard Hill Ltd., -1963).

Butler, David, and Freeman, Jennie, British Political Facts, 1900 1967 (London: MacMillan Co., 1968).

Butler, David, and Stokes, Donald, Political Change in Britain (New York: St. Martin's Press, 1969).

Central Office of Information, Economic Progress Report, monthly from January, 1970.

Central Office of Information, The New Towms of Britain, Reference Pamphlet No. 44 (London: HMSO, January, 1969).

Central Office of Information, Regional Development in Britain, Reference Pamphlet No. 80 (London: HMSO, 1968).

Central Office of Information, Town and Country Planning in Britain Reference Pamphlet No. 9.

Chancellor of the Exchequer, The Selective Employment Tax, Command No. 2986 (London: HMSO, 1966).

Chapman, Richard A., Decision Making (Lond on: Routledge \& Kegan Paul, 1969).

Chester, D. N., "Local Finance," Political Quarterly (London), Vo1. 37, April, 1966.

Christoph, James B., "The Birth of Neddy," Cases in Comparative Politics, James B. Christoph, Editor (Boston: Little Brown \& Co., 1965).

(The) Civic Trust, The Civic Society Movement (London: The Civic Trust, 1968). 
Commission for the New Towns, Report of the Commission for the New Towns (London: HMSO, July, 1969).

Committee Under the Chairmanship of Sir Joseph Hunt, The Intermediate Areas (Lond on: HMSO, April, 1969).

Committee on Public Participation in Planning, A. M. Skeffington, M.P., Chairman, People and Planning (London: HMSO, 1969).

Council for Small Industries in Rural Areas, pamphlet on loans (London: CSIRA, Credit Services Division).

Crick, Bernard, "The 1970's in Retrospect," Political Quarterly (London), Vo1. 41, No. 1, January-March, 1970.

Crosland, Anthony, President, Board of Trade, "Industrial Estates for Areas Affected by Colliery Closures," (Extract) Board of Trade Journal (London: BOT, November 17, 1967).

Crosland, Anthony, "A Progress Report on the Development Areas," (Extract) Board of Trade Journal (London: BOT, March 29, 1968).

Cullingworth, J. B., and Karn, V. A., Ministry of Housing and Local Government, The Ownership and Management of Housing in the New Towns (London: HMSO, 1968).

Daniels, P. W., "Office Decentralisation from London--Policy and Practice," Regional Studies (Oxford), Vol. 3, No. 2, September, 1969)

Department of Economic Affairs, Changing Britain (Broadsheets on Britain), Monthly, May, 1966 - February, 1968.

Department of Economic Affairs and Central Office of Information, Economic Planning in the Regions (Ashford, Kent, England: HMSO, 1968).

Department of Economic Affairs, Industrial and Regional DEA Progress Report, Nos. 33, 42, 48, 51, 54, and 56 (October, 1967; July, 1968; January, 1969; April, 1969; July, 1969; September, 1969).

Department of Economic Affairs, Progress With Regional Economic Planning (London: DEA Background Paper, Mimeographed, November, 1967).

Department of Economic Affairs, The Task Ahead (London: HMSO, 1969).

Department of Employment and Productivity, Implementation of the Industrial Training Act 1964, Progress Report No. 13 (London: DEP, 1969). 
Department of Employment and Productivity, Industria1 Training in Great Britain (Lond on: DEP, May, 1969).

Development Corporations (New Towns Act 1965), Reports of the Development Corporations (London: HMSO, July, 1969).

Dollan, James, "New Mixture for a New-Town," New Statesman, Vo1. 73, March 10, 1967.

Donnison, David, and Levin, Peter, "People and Planning," Public Administration_(London), Vol. 43, No. 4, Winter, 1965.

Economic Brief; "Labour's First Five Years--The Quiet Revolution," Vol. 2, No. 10, Special Issue (London: The Labour Party of the United Kingdom, 1970).

Economic Brief, "Socialism v. Toryism--Where the Difference Shows," Vol. 3, No. 2 (London: The Labour Party of the United Kingdom, March, 1970).

(The) Ever Ready Company (GB) Ltd., Stanley, County Durham, Opening of the New Factory at Tanfield Lee (published by The Ever Ready Co. for plant dedication, July 10, 1968).

Forster, Sir Sadler (Chairman), Location of Industry Policy in Britain from 1934 to 1960 (The English Industrial Estates Corporation, Mimeographed, 1961).

Forster, Sir Sadler (Chairman), The British Government's Trading Estates, An Example of Location of Industry in Practice (The English Industrial Estates Corporation, Mimeographed, 1961).

Freeman, T. W., Geography and Planning (London: Hutchinson University Library, 1958).

Friend, J. K., and Jessop, W. N., Local Government and Strategic Choice: An Operational Research Approach to the Processes of Public Planning (London: Tavistock Publications, 1969).

Frost, David, and Jay, Anthony, The English (New York: Stein and Day, 1968).

Gimbrin, Hoyt, "New Towns," Editorial Research Reports on the Urban Environment, Willlam B. Dickinson, Jr., Editor (Washington, D.C.: Congressional Quarterly, January, 1969).

Gowan, Ivor, and Gibson, Leon, "The Royal Commission on Local Government in England: A Survey of Some of the Written Evidence," Public Administration (London), Vol. 46 (1), Spring, 1968.

Great Britain, Britain 1971, An Official Handbook (London: HMSO, 1971). 
Grebber, Leo, Urban Renewal in European Countries: Its Emergence and Potentials (Philadelphia: University of Pennsylvania Press, 1964).

Grime, E. K., and Starkie, D. N. M., "New Jobs for 01d: An Impact Study of a New Factory in Furness," Regional Studies (Oxford), Vo1. 2, No. 1, September, 1959.

Grove, J. L., and Procter, S. C., "Citizen Participation in Planning," Journal of the Town P1 anning Institute, Vol. 52, December, 1966.

Hal1, Sir Robert, and Plowden, Lord, "The Supremacy of Politics," The Political Quarterly (London), Vol. 39, October, 1968.

Hart, Sir William, "The Conurbations and the Regions," The Political Quarter1y (London), Vo1. 27, No. 2, April-June, 1966.

Highlands and Islands Development Board, Third Report (1st January, 1968 to 31 st December, 1968) (Inverness: June, 1969).

Industrial Estates Corporation of England, "Distribution of Industry Policy," (Newcastle: Board of Trade, Mimeographed, 1969).

(The) Institute of Economic Affairs, Ltd., Growth Through Industry (London: Univen Bros., Ltd., 1967).

(The) Institute of Economic Affairs, Ltd., Private Capital for New Towns (Lond on: The IEA, 1969).

Jay, Douglas, M. P., "Government Control of the Economy: Defects in the Machinery," Political Quarterly (London), Vol. 39, April, 1968.

Jennings, Hilda, Societies in the Making: A Study of Development and Redevelopment Within a County Borough (London: Routledge \& Kegan Paul, 1962).

Johns, A. E., The Social Structure of Modern Britain (London: Pergammon Press, Ltd., 1966).

Jones, G. H.; Smith, B. D.; and Wiseman, H. V., "Regionalism and Parliament," Political Quarterly (Lond on), Vol. 38, No. 4, October-Dec ember, 1967.

Jupp, James, Political Parties (London: Routledge and Kegan Paul, 1968).

Lean, W., "Economic Studies and Assessment of Town Development," Journal of the Town Planning Institute, Vol. 53, No. 4, Apri1, 1967. 
Lorwin, Val R., "Working-Class Politics and Economic Development in Western Europe," Comparative Political Parties: Selected Readings, Andrew J. Milnor, Editor (New York: Thomas Y. Crowel1 Co., 1969).

Mather, Sir William, "Conference Report: York Conference of Amenity Societies, 27-29 September, 1968," The Civic Trust (London: Mimeographed, 1968).

McCrone, Gavin, Regional Policy in Britain (London: George Allen and Unwin, Ltd., 1969).

McLough1in, J. Brian, "The Changing State of British Practice," Journal of the American Institute of Planners, Vo1. 32, -.... November, 1966.

Miller, Delbert C., "Decision-Making Cliques in Community Power Structures: A Comparative Study of an American and an English City," American Journal of Sociology, Vo1. 64, November, 1958.

Ministry of Housing and Local Government, Joint Circular 66/68, "Town and Country Planning Act, 1968," (Whitehall, London: HMSO, 1968).

Ministry of Housing and Local Government and Welsh Office, Old Houses Into New Homes, Command No. 3602 (London: HMSO, April, 1968).

Ministry of Labour, "Assistance With Industrial Training for Firms in Development Areas," pamphlet (London: HMSO, October, 1967).

Ministry of Labour, "Grants and Allowances to Transferred Workers," pamphlet (Turnbridge Wells: HMSO, September, 1966).

Ministry of Labour, Regional Employment Premium: Notes for Employers With Manufacturing Establishments in Development Areas

(Lond on: HMSO, August, 196.7).

Mishan, E. J., "Economic Priority: Growth or Welfare?" The Political Quarterly (London), Vo1. 40, No. 1, January, 1969.

Morrison, Herbert, Government and Parliament: A Survey from the Inside (Lond on: Oxford University Press, 1954, revised 1959 and 1964).

Munby, Denys, "More Light on Priorities--A Symposium," The Political Quarterly (London), Vol. 39, October, 1968.

Musgrove, P. W., The Economic Structure (Lond on: Longmans, Green and Co., Ltd., 1969).

National Institute Economic Review, "The Green Paper on the Development Areas," NIER, No. 40, March, 1967. 
National Institute Economic Review, "Regional Problems and Regional Policy," NIER, No. 16, November, 1968.

(The) Nature Conservancy, The Standing Committee of The Countryside in 1970, European Conservation Year, United Kingdom (London: The Nature Conservancy, 1970).

Nendes, Richard H., Bibliography on Community Organization (Washington, D. C.: President's Commission on Juvenile Delinquency and Youth Crime, June, 1965).

Newton, K., "City Politics in Britain and the United States," Political Studies (London), Vol. 27, No. 2, June, 1969.

Nichols, Harry R., Labour's Economic Strategy (London: The Labour Party).

Northern Economic Planning Council, Challenge of the Changing North (Lond on: HMSO, 1966).

Northern Economic Planning Council, Challenge to Northerners: You and the Region's Development (London: HMSO, 1966).

Northern Economic Planning Council, Outline Strategy for the North (Newcastle: NEPC, 1969).

Northern Economic Planning Council, Regional Ports Survey (Newcastle: NEPC, 1969).

Northern Economic Planning Council, Working Group on Manpower, Vocational Training in Northern Region (Newcastle: Department of Employment, June, 1969).

North East Development Council, Annual Reports, 1966-67, 1967-68, 1968-1969.

North East Development Council, A Guide to Government Incentives for Firms Expanding in North East England (Newcastle: NEDC, April, 1969).

North Eastern Trading Estates, First Edition Handbook--Industrial Estates (Newcastle: Mimeographed, 1952).

North East Development Council, North East England--Location for Industry (Newcastle: NEDC, June, 1969)."

North East Development Council, A Survey of the Experience of Some North East Firms in Applying for Government Grants and Loans (Confidential) (Newcastle: Mímeográphed, NEDC, January, 1968.

North East Development Council, "This is a Business Proposition," pamphlet (Newcastle: NEDC, 1969). 
Organisation for Economic Co-operation and Development, Manpower Policy In the United Kingdom (Paris: Mimeographed, April, 1968).

Osborn, Frederick J., and Arnold Whittick, The New Towns: The Answer to Megalopolis (London: Leonard Hill Ltd., 1963).

Osborne, John, Britain: The Land, The People, The Spirit (New York: Time, Incorporated, 1967).

Owen, C., Social Stratification (London: Routledgr \& Kegan Paul, 1968).

Peterson, A. W., "Regional Economic Planning Councils and Boards," Department of Economic Affairs, Mimeographed, November 15, 1965).

Political Quarterly (London), "Participation, Priorities and Planning," Vol. 39, October, 1968 .

Pritchard, Norman, "Planned Social Provision in New Towns," The Town Planning Review, Vol. 38, No. 1, April, 1967.

Robertson, Andrew, and Robertson, Jean, "Concrete Proposals for 2000 A. D. " New Statesman (London), Vo1. 76, October 4, 1968.

Robson, William A., "Local Government in the Welfare State," Political Quarterly (London), Vol. 37, April-June, 1966.

Rodgers, H. B., "The Hunt Report: Prospects for Pennine England," Area, No. 3, 1969.

Rotstein, Arthur H., "Britain Proves Urban Renewal $\mathrm{C}$ an Work and Improve Lines," Government Executive, December, 1969.

Rowe, Eric, Modern Politics: An Introduction to Behaviour and Institutions (London: Routledge \& Kegan Paul, 1969).

Royal Commission on Local Government in England, Report, Volumes I, II, and III (Lond on: HMSO, June, 1969).

Royal Institute of International Affairs, Inquest on Planning in Britain (London: Political and Economic Planning, Vol. XXXIII, No. 499, January, 1967).

Secretary of State for Economic Affairs and Chancellor of the Exchequer, The Development Areas: Regional Employment Premium (Lond on: HMSO, June, 1967).

Secretary of State for Economic Affairs and Ministry of Technology, Industrial Expansion (London: HMSO, 1968).

Self, P. J. O., "Regional Planning in Britain: Analysis and Evaluation," Regional Studies (Oxford), Vol. 1, No. 1, May, 1967. 
Sharp, Evelyn, The Ministry of Housing and Local Government (London: George Allen and Unwin, Ltd., 1969).

Sharpe, L. S., Editor, Voting in Cities, The 1964 Borough Elections (London: MacMillan Co., 1967).

Sharpe, Sumner M., "Depression and Industrial Planning in Great Britain" (Unpublished Thesis, 1958-59).

Silver, Nathan, "Against New Towns," New Statesman (London), August 2, 1968.

Smith, Brian C., Advising Ministers: A Case-Study of The South West Economic Planning Council (London: Routledge \& Kegan Paul, 1969).

Smith, D. M., "Identifying the 'Gray' Areas," Regional Studies (Oxford), Vo1. 2, November, 1968.

Standish, J. F., "Regionalism in Britain," Contemporary Review (London), Vo1. 208, February, 1966.

Suski, Julian G., "The Structure of Municipal Government in Canada and Europe," Canadian Public Administration, Vol. VIII (3), September, 1965.

Thomas, Ray, Aycliffe to Cumbernauld: A Study of Seven Towns in Their Regions (London: Political and Economic Planning, 1969).

Tivey, Leonard, "The Political Consequences of Economic Planning," Parliamentary Affairs, Vol. 20, Autumn, 1967.

Turner, D. R., The Shadow Cabinet in British Politics (London: Routledge \& Kegan Paul, 1969).

United Nations, Department of Economic and Social Affairs, Industrial Estates: Policies, Plans and Progress (New York: United Nations, 1966).

U. S. Economic Development Administration, Management Surmary Report, Quarterly (Washington, D. C.).

Verney, Douglas, V., British Government and Politics (Lond on: Harper and Row, 1966).

Vickers, Sir Geoffrey, "Planning and Policy Making," Political Quarterly (London), Vol. 38, July, 1967).

Waugh, M., "The Changing Distribution of Professional and Managerial Manpower in England and Wales Between 1961 and 1966," Regional Studies (Oxford), Vol. 3, September, 1969. 
White, Peter A., Portrait of County Durham (London: Robert Hale, Ltd., 1967).

Wilkinson, Rupert, Editor, Governing Elites (New York: Oxford University Press, 1969).

Wiseman, H. Victor, "Regional Government in the United Kingdom," Parliamentary Affairs (London), Vol. XIX, No. 1, Winter, 1965-66. 


\section{INDEX}

Advance factories, 33, 176

Agriculture, U. S. Department of, 3

Appalachian Commission, 2, 94

Area Redevelopment Administration (ARA), 1, 2, 25, 48, 73, 93, 191

Balanced growth era, $174,177,179$

Barl ow Rep ort, 29, 43, 163, 112

Board of Trade, $32,41,51,58,67,71,92,111,112,123$, (a1 so see

Department of Trade and Industry)

Board of Trade Advisory Committee (BOTAC), 69, 76, 92

Building grants, 71

Cadco developments, 82

Citizen participation, $6,148,151,183$

Civic Trust, 163, 168

Commerce, U. S. Department of, 65

Commission for Special Areas, 111

Community power studies, 159

Congressional Joint Economic Comnittee, 25

Conservative Government and Party, 35, 36, 63, 80, 84, 100, 103, 117, $129,183,185,186,191$

Consumer Association, 165

Controls on location, $32,40,62,177,180,191$

Council for Preservation of Rural England, 164

Council for Small Industries in Rural Areas, 71

Defense Memorandum No. 4, 24

Defense Mobilization, Office of, 25

Democratic Party, 34

Depreciation write-off, 76, 176

Derelict areas, 32, 56, 58, 84, 176

Development areas and districts, $41,42,47,50,52,53,55,58,68$, $84,100,168,184,188,190$

Development Areas Treasury Advisory Committee, 48, 69

Distribution of Industry Acts, 32, 33, 42, 71

Distribution of the Industrial Population, Royal Commission on, 29, 112

Durham, County of, 17, 91, 193

Economic Affairs, Department of, 119, 123, 126, 137

Economic Development Administration (EDA), 3, 34, 72, 93, 149, 163, $174,1.91$

Economic planning, 117,142

Education and training, 78

Employment Policy, White Paper on, 17, 31 
INDEX

English Industrial Estates Corporation, 12, 16, 61

Ever Ready Company, Ltd., 66

Finance Act of 1963,76

Forster, Sir Sadler, 12

Ful1 employment, 24, 176

Government-built factories, $32,41,63,188$.

Government contracts, 176

Government training centers, 81

Grants to industry, $32,68,188$

Housing, 96,100

Housing and Local Government, Ministry of, 58, 97, 112, 149, 166

Hunt Committee, 56

Industrial area, xii

Industrial Development Act of 1966, 68, 71, 76

Industrial development certificate (see controls on location)

Industrial estate or trading estate, xii, 58, 60

Industrial Estates Corporation of England, 12, 16, 61

Industrial location, control of, 32, 40,62, 177, 180

Industrial park, xii, 10

Industrial training boards, 78

Industrial Transference Board, 27

Industrial zone, xii

Intermediate areas, $54,58,84$

Investment grants, 68,188

Job development era, $174,175,176$

Labour Government and Party, 32, 34, 36, 57, 58, 63, 79, 102, 123, $129,165,170,178,183,185,186,191$

Loans and grants to industry, $32,68,70,176,188$

Loans and grants to local government, 32, 176

Local Development Corporation, 152, 153, 157

Local Employment Acts of 1960-1966, 33, 51, 68, 96, 175, 188

Local Government, Royal Commission on, 88

Location controls, 32, 40, 177, 180, 191

Manpower Training and Development Act, 2

Maud Report, 88, 131, 183

National Defense Tax, 76

National Economic Development Council (NEDC), 51, 114, 119

New towns, 30, 58, 100, 105, 108, 176, 178, 179, 191

New Towns Acts, 103

Nor th East Development Board, 13

North East Development Association, 121 


\section{INDEX}

North East Development Council, 73, 92

North East Industrial Estates Corporation, 16

North East Region, 13, 123

Northern Economic P1anning Council, 137

Northern Region, 64, 108, 129, 133, 137, 145, 170

Organisation for Economic Co-operation and Development (OECD), 109, 116

Overal1 Economic Development Committee, 4, 149, 153, 155

Overal1 Economic Development P1an, 4

Party allegiance, 145

Planning, 7, 88

Planning Advisory Group, 89

Pressure groups, 162

Public Participation in Planning (Committee on), 166, 184

Public Works and Economic Development Act of 1965, 2

Rapid tax amortization (depreciation), 76, 176

Rate efficiency grants, 95

Rate support grants, 94

Reconstruction Finance Corporation, 70

Redc1iffe-Maud Report, 88, 131, 183

Regional Employment Premium (REP), 77, 85, 178, 179

Regional planning boards and councils, 117, 123,131, 155, 179, 182

Regional policy and planning, 35, 42, 106, 111, 120, 125, 143, 176, 182,186

Resource development era, 174, 175, 176

Retraining, 32, 176

Sanders, George, 82

Selective Employment Tax (SET), 77, 84, 178, 179

Skeffington Committee and Report, 166, 184

Slough Estates, Ltd., 57

Smal1 Business Administration, 3, 152, 158, 163

South East Study, 90

South West Planning Council, 126, 136

Special areas, $32,38,39,49,60,84$

Special Areas (Development and Improvement) Act, 28, 46, 112, 180

Special Areas Loan and Advisory Commission, 29

Special Areas Reconstruction (Agreement) Act, 1936, 28

Special Areas Reconstruction Association, Ltd. (SARA), 28, 70

Special development areas, 54, 55, 58,69, 190

Special purpose grant, 95

Tax concessions, 76

Team Valley Trading Estates, 10, 15, 59 .

Technology, Ministry of, 65

Tennessee Valley Authority, 24

Town and Country Planning Act, 7, 32, 89, 166 


\section{INDEX}

Town and Country Planning Association, 164

Town and Country Planning, Ministry of, 112

Trade and Industry, Department of, 149, 168, 187 (also see Board of Trade)

Trading estates, xil, 10, 13, 30, 159

Training, 78

Voting results, 145 